\author{
UNIVERSIDADE DE SÃO PAULO \\ FACULDADE DE FILOSOFIA, LETRAS E CIÊNCIAS HUMANAS \\ DEPARTAMENTO DE ANTROPOLOGIA \\ PROGRAMA DE PÓS-GRADUAÇÃO EM ANTROPOLOGIA SOCIAL
}

\title{
Elementos de etnografia Mbyá: lideranças e grupos familiares na aldeia Tekoá Pyaú (Jaraguá - São Paulo, SP)
}

Fabio de Oliveira Nogueira da Silva

\begin{abstract}
Dissertação apresentada ao Programa de Pós-Graduação em Antropologia Social do Departamento de Antropologia da Faculdade de Filosofia, Letras e Ciências Humanas da Universidade de São Paulo, para a obtenção do título de Mestre em Antropologia Social.

Área de Concentração: Etnologia Indígena.
\end{abstract}

Orientadora: Profa. Dra. Marta Rosa Amoroso

São Paulo 


\section{FOLHA DE APROVAÇÃO}

Fabio de Oliveira Nogueira da Silva

Elementos de etnografia Mbyá: lideranças e grupos familiares na aldeia Tekoá Pyaú (Jaraguá - São Paulo, SP)

Dissertação apresentada ao Programa de Pós-Graduação em Antropologia Social do Departamento de Antropologia da Faculdade de Filosofia, Letras e Ciências Humanas da Universidade de São Paulo, para a obtenção do título de Mestre.

Indígena.

Área de Concentração: Etnologia

Aprovado em:

Banca Examinadora

$\operatorname{Prof}(\underline{a}) \operatorname{Dr}(\stackrel{a}{)})$

Instituição:

Assinatura:

$\operatorname{Prof}(\stackrel{\mathrm{a}}{)}) \operatorname{Dr}(\underline{a}):$

Instituição:

Assinatura:

$\operatorname{Prof}\left({ }^{\underline{a}}\right) \operatorname{Dr}(\stackrel{a}{)}):$

Instituição:

Assinatura: 
Dedicatória

A minha esposa e a minha filha, que compreenderam minhas ausências e deram-me o incentivo para seguir em frente sempre que parecia impossível. 


\section{Agradecimentos}

À Fapesp, pelo apoio à pesquisa.

Ao Temático "Missões Religiosas em áreas indígenas", coordenado pela professora Paula Montero, em cujos encontros e debates pude acessar as mais recentes discussões e teorias da antropologia.

À minha orientadora, Prof ${ }^{-} \mathrm{Dr}^{\mathrm{a}}$ Marta Rosa Amoroso, que com grande paciência ajudou-me a encontrar caminhos em meio ao cipoal em que eu me metera; pela permanente presença no desenvolvimento do trabalho e, ao mesmo tempo, pelo respeito com que tratou (e trata) minhas escolhas. Isso significa, evidentemente, que eventuais equívocos aqui presentes são de minha inteira responsabilidade, pois os riscos que assumi não passaram sem que me fossem dados os devidos alertas.

À Prof ${ }^{\mathrm{a}} \mathrm{Dr}^{\mathrm{a}}$ Dominique T. Gallois, que forneceu importantes elementos para reflexão sobre a produção acadêmica a respeito dos Guarani, principalmente no que diz respeito à ausência de diálogo que tal produção teima em não estabelecer com a imensa e rica etnologia de outras áreas das Terras Baixas.

Aos Guarani de todas as aldeias que me acolheram com o coração aberto, com generosidade e paciência; principalmente aos Guarani no Jaraguá, que me reservaram um lugar especial na aldeia, baseados nas relações de confiança mútua que estabelecemos.

Aos membros do Oim Porã ma Oré Rekó, Grupo Interdisciplinar de Extensão Universitária, pela amizade e pela troca de experiências.

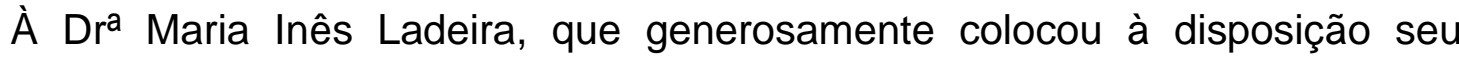
acervo particular, com documentos, mapas e dados coletados nesses anos de intensa atuação indigenista e acadêmica junto aos Guarani - a história desses índios em São Paulo reserva a Inês Ladeira um capítulo bastante especial. 


\section{Resumo}

NOGUEIRA DA SILVA, Fabio de O. Elementos de etnografia Mbyá: lideranças e grupos familiares na aldeia Tekoá Pyaú - Jaraguá - SP. 2007. 207 f. Dissertação (Mestrado). Faculdade de Filosofia, Letras e Ciências Humanas, Universidade de São Paulo, São Paulo, 2007.

O presente trabalho tem como objetivo apresentar dados etnográficos sobre os Guarani Mbyá nas aldeias Tekoá Ytu e Tekoá Pyaú, localizadas junto ao Parque Estadual do Jaraguá, em São Paulo, capital. Foram priorizados os elementos relativos à organização social, parentesco e liderança, os quais formam o pano de fundo desta etnografia. As lideranças indígenas Mbyá são aqui compreendidas como um locus privilegiado para a observação das relações internas do grupo indígena, das relações entre as famílias extensas, entre aldeias diferentes e com os não índios. Suas opiniões, classificações e ordenamento das identidades e das alteridades produzidas nessas relações são descritas e colocadas em diálogo com a literatura etnológica Mbyá clássica e atual. Por fim, discuto a pertinência de se explorar a noção de tekó (o "modo de ser") Guarani para se compreender as construções socioculturais deste grupo indígena, e também sugerindo que tal noção participa de forma importante da cosmovisão Mbyá. Também apresento um levantamento sobre a produção acadêmica (Teses e Dissertações) que tem os Guarani como foco de análise. São quase duzentas monografias, de diversas áreas do conhecimento e de diversas instituições de ensino e pesquisa no Brasil, finalizadas a partir da década de 1980. Analiso alguns dos dados que podem ser obtidos desse levantamento, observando o crescimento exponencial dos estudos sobre os Guarani nas últimas décadas.

Palavras-chave: Guarani, Mbyá, Jaraguá, Parentesco, Liderança. 


\section{Abstract}

NOGUEIRA DA SILVA, Fabio de O. Elements of Mbyá Ethnography: leadership and kinship on the Tekoá Pyaú indigenous land - Jaraguá - SP. 2007. 207 f. Thesis (M.A.). Faculdade de Filosofia, Letras e Ciências Humanas, Universidade de São Paulo, São Paulo, 2007.

This work seeks to present ethnographic data concerning the Guarani Mbyá from the Tekoá Ytu and Tekoá Pyaú indigenous lands, located near the Jaraguá State Park in the capital city of São Paulo. Elements pertaining to social organization, kinship, and leadership are given priority, constituting the basis of this ethnography. The indigenous Mbyá leaders are thus seen as a privileged locus for observing relations internal to the indigenous group, relations between kinship groups, among different indigenous lands and with non-indigenous people. Their opinions, classifications and ordering of identities and alterities produced in these relations are described and put in dialogue with the classic and contemporary Mbyá ethnology. In conclusion, I discuss the pertinence of exploring the notion of the tekó ('way of being') Guarani to understanding the sociocultural constructs of this indigenous group and suggest the importance of this notion to the Mbyá cosmovision. I also include a bibliographic survey of academic research (Thesis and Dissertations) focused on the Guarani. There are almost two-hundred monographic works from different areas of knowledge and different educational and research institutes in Brazil, from the decade of 1980 on. I present an analysis of some information gathered from this survey, observing the exponential expansion of studies concerning the Guarani during the last decades.

Keywords: Guarani, Mbyá, Jaraguá, Kinship, Leadership 


\section{Sumário}

Introdução

Capítulo I - A história guarani do Jaraguá ................................................. 20

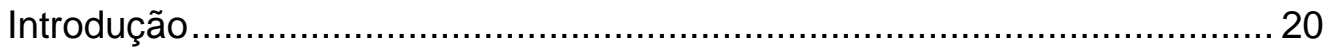

1 - A formação da aldeia Tekoa Ytu e o Parque Estadual do Jaraguá.......... 22

2 - Alguns elementos das trajetórias de vida de Joaquim e Jandira ............. 25

3 - Formação, características e cotidiano da aldeia Tekoa Ytu................... 31

4 - Breves apontamentos sobre o bairro do Jaraguá e região .................... 42

5 - Elementos da presença indígena na região do Jaraguá e da história local antes das aldeias atuais.

Capítulo II - Tekoá Pyaú: história e etnografia .......................................... 50

Introdução ........................................................................................... 50

1 - Elementos da trajetória de vida de lideranças do Tekoa Pyau ...............51 51

$a-$ Karai Poty (José Fernandes) ......................................................... 53

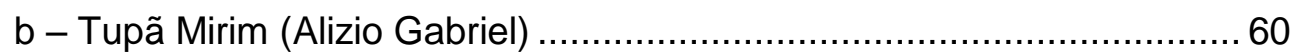

c - Os Macena: Karai Tataendy (Pedro Macena), Vera Mirim (Wiliam Macena) e

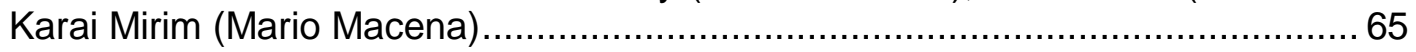

2 - Formação do Tekoa Pyau ............................................................... 73

3 - Características do Tekoa Pyau ........................................................ 75

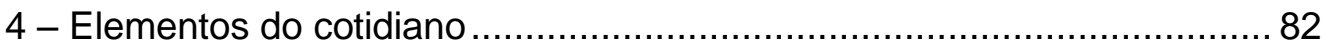

Capítulo III - Oo, kuerya katu, tekoa: noções de espacialidade e relações de aliança e parentesco na organização social da aldeia Tekoa Pyau ........................93

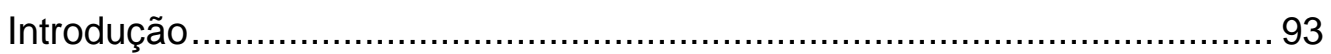

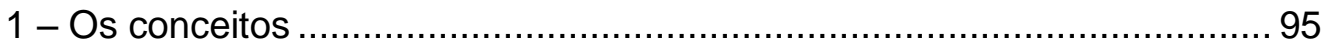

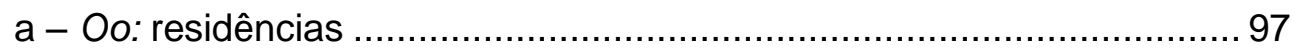

b - Kuerya katu: núcleos de residências ............................................. 99

c - Etarã: famílias extensas ........................................................... 101

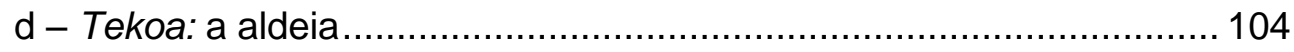

2 - Notações sobre espacialidade e organização social no Tekoa Pyau....106 


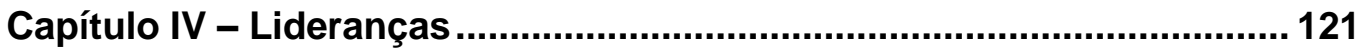

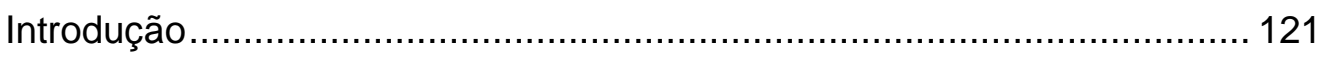

1 - Como pode ter surgido o conceito de liderança ................................. 124

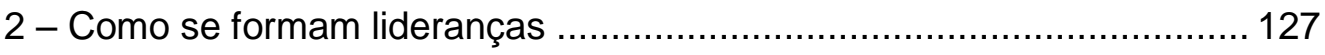

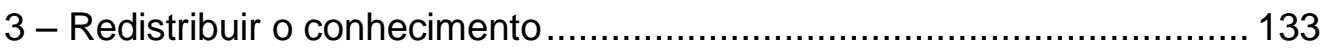

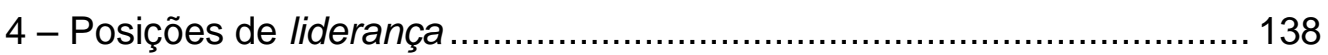

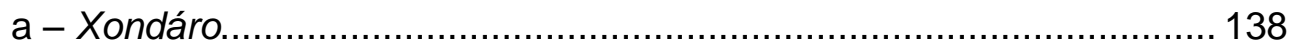

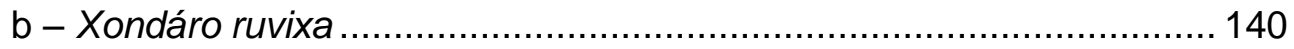

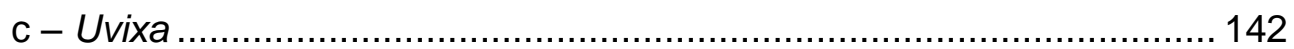

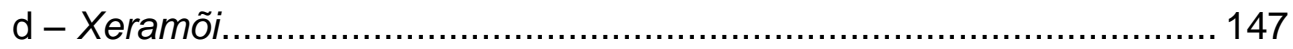

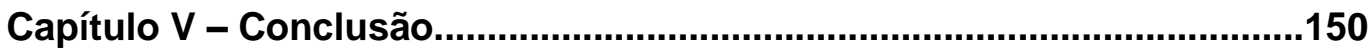

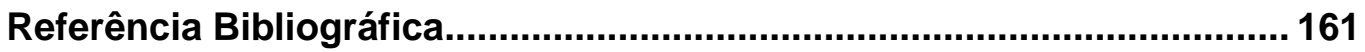

Anexo A: A produção acadêmica sobre os Guarani .................................165

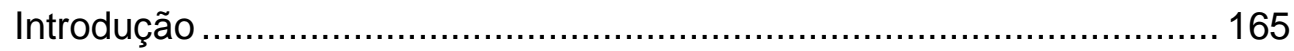

Lista de obras por data: Teses e Dissertações ....................................... 166

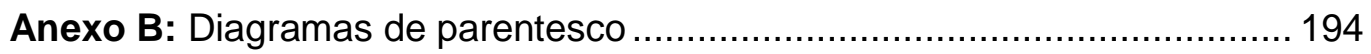

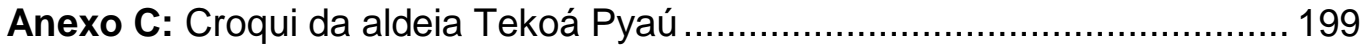

Anexo D: Fotos - as aldeias guarani e o bairro do Jaraguá.......................... 202

Anexo E: Diagramas de organização sócio-espacial: Kaiowá e Mbya .......... 205 


\section{INTRODUÇÃO}

O trabalho teve como objetivo inicial um levantamento bibliográfico da produção etnológica sobre os Mbyá, com ênfase nos dados sobre as relações entre esse grupo indígena e religiosos evangélicos. Chamava-me a atenção o fato de que parecia haver pouquíssima inserção desses religiosos, assim como de toda a máquina missionária, no cenário indígena do Sul e Sudeste brasileiros. As monografias pesquisadas reforçavam a idéia de que de fato havia um vazio dessa presença exatamente pela quase total inexistência de estudos a esse respeito, limitando-se a comentários inseridos em contextos diversos dos produtos acadêmicos.

Nesse mesmo período de leituras e pesquisa bibliográfica foi-se amadurecendo a reflexão de que a relação dos Mbyá com evangélicos (missionários profissionalizados ou não) não poderia ser tratada isoladamente, sem referência ao conjunto de relações que os agentes constroem, pois esse tipo de recorte traria prejuízos ao rendimento das análises, mesmo que elas focassem apenas a empresa evangélica. Os agentes em campo nunca estão isolados do contexto, pois nele relacionam-se diversas redes de agentes, e cuja dinâmica é por eles apreendida de forma consciente (mesmo que não em totalidade). Por exemplo, um missionário evangélico que pretende iniciar o trabalho junto a um grupo a partir de ações de alfabetização não pode ignorar a presença de uma escola salesiana, pública, ou mesmo o trabalho que eventualmente outros religiosos evangélicos possam estar desenvolvendo.

Assim, para resolver o problema da carência de dados a respeito da presença de evangélicos em áreas Mbyá, passei a coletar dados primários, diretamente em 
campo, nas aldeias junto ao Pico do Jaraguá, em São Paulo. As informações de que dispunha indicavam que essa área traria bom rendimento para as questões que investigava. Além do fato de que o fundador da primeira das aldeias, o falecido Joaquim, declarava-se evangélico, havia a informação de que um de seus filhos também era seguidor de uma religião pentecostal e realizava ali os cultos. Esses dados se confirmaram nas observações de campo: tanto a viúva de Joaquim (a atual cacique da aldeia Tekoá Ytu, Jandira) confirmou que Joaquim se dizia evangélico, como ainda hoje os cultos são realizados nas aldeias.

Nos primeiros meses em que estive na área, no entanto, percebi que havia uma rarefação dessa presença, com poucos evangélicos realizando cultos, visitas, ou prestação de assistencialismo com fins proselitistas. Os cultos que Mário (o filho evangélico de Jandira) realizava eram em sua própria casa e apenas aos domingos, mas nem sempre aconteciam, e nunca contavam com a participação de qualquer outro morador da aldeia. Os evangélicos que faziam visitas com fins proselitistas, levando presentes como brinquedos, comidas, roupas, foram proibidos pela cacique de entrar na área: várias pessoas reclamaram que as comidas que os religiosos levavam quase sempre estavam fora do prazo de validade, impróprias para o consumo, causando algumas vezes problemas de saúde, principalmente nas crianças (que consumiam vorazmente os iogurtes e salgadinhos enquanto ouviam cânticos e algumas pregações). E assim permanece até hoje, pouco mais de um ano e meio do ocorrido.

Mas ao mesmo tempo em que este "fechamento" ocorreu na aldeia Tekoa Ytu, liderada por Jandira, na aldeia Tekoa Pyau deu-se o contrário, e evangélicos instalaram-se na aldeia construindo uma grande armação de ferro, coberta de lona onde realizavam cultos uma vez por semana, ainda que sem muita regularidade. No 
entanto, essa não era a situação anterior. A aldeia de José Fernandes, Tekoa Pyau, era mais fechada à presença desses religiosos, que não chegavam a ter sua entrada impedida, pois o cacique afirma que se eles (os evangélicos) estão ali é porque Nhanderu ete, criador do mundo, os estava mandando. E, por nem sempre serem bem recebidos pelo restante da aldeia, dificilmente os evangélicos faziam lá os seus cultos.

Após a tomada de posição mais firme pelos membros do Tekoa Ytu, proibindo a presença dos evangélicos, a entrada dos evangélicos no Tekoa Pyau foi mais do que facilitada. Não que os Guarani tenham passado a freqüentar os cultos, pois estes continuam contando com a presença apenas dos visitantes, mas há agora praticamente um templo sendo construído em uma aldeia onde se recusavam a recebe-los (a maior construção no local é escola, e a segunda maior é a "tenda" dos evangélicos, o que pode ser observado na foto em anexo).

Então, o que teria mudado? Por que as posturas adotadas nas duas aldeias em relação aos evangélicos se inverteram? Essa questão levou-me para locais mais profundos das aldeias e, daí, para novas questões. O que passou a tomar todo o meu campo de visão nas observações não era mais a presença dos evangélicos, mas a relação entre as aldeias. Foi a partir daí que o trabalho de campo passou a focar as diversas possibilidades de relações que se estabeleciam na constituição de alteridades e identidades.

Dessa forma, ao trazer uma nova problemática (a diversidade agentes em relação) para o material bibliográfico que havia coletado, e ao transferir a busca de dados para o campo, o trabalho tomou novo rumo. E, uma vez que a proposta de trabalho não incluía a descrição de redes de relações (pois exigiria uma bibliografia teórica específica), optei por buscar a compreensão de como as lideranças das 
aldeias operavam as relações com uma diversidade de agências a partir dos múltiplos pontos de vista que poderiam assumir.

No exame de qualificação foi sugerido que eu atentasse para a inexistência de uma etnografia daquelas aldeias. A particularidade delas exigia que informações básicas fossem recolhidas e descritas, sendo necessárias para qualquer outro aprofundamento daquela paisagem sociocultural. Assim, o rumo que este trabalho tomou foi o de uma etnografia das aldeias tendo como pano de fundo as questões das posições (lugares) das lideranças em sua relação com diversos agentes e as constituições de alteridades e identidades.

A riqueza das informações obtidas foi certamente suficiente para a elaboração de uma monografia que trouxesse acréscimos para a etnologia indígena mesmo com um tempo já se tornando escasso para a pesquisa. Junta-se a isso o fato de haver composto um razoável acervo de Teses e Dissertações sobre os Guarani, permitindo um vôo de pássaro sobre o estado da arte dos estudos Mbyá.

Os estudos clássicos (Schaden, Nimuendaju) sobre os Guarani foram produzidos sob a orientação do tema da aculturação, até por volta dos anos 1960 . Para a etnologia os Guarani estavam prestes a finalizar algum dos dois destinos possíveis: o desaparecimento total, físico, morrendo por fome, pela ação de posseiros e fazendeiros e pela omissão do Estado; ou, a completa integração e assimilação pela sociedade envolvente, tornando-se indiferenciados do campesinato, do caipira, ou dos trabalhadores pobres dos latifúndios. A Amazônia ou o Brasil Central viria a ser, desde então, o foco da produção etnológica no Brasil. Enquanto isso, os Guarani permaneceriam invisíveis, tanto para a academia como para o Estado, que não produziu políticas de ação junto a esse grupo indígena nem a proteção de suas terras. 
Somente à partir dos anos 1970, com o aumento da densidade da ocupação populacional no entorno (e na) Mata Atlântica, por causa da construção de grandes rodovias de acesso ao litoral e conseqüente valorização fundiária, é que os Guarani passaram a ser notados (e a fazer-se notar). Até então, o trabalho do órgão de proteção aos índios em São Paulo resumia-se a forçar o aldeamento dos Guarani que chegavam de diversas localidades (Leste do Paraguai, Norte da Argentina, dos estados do Sul do Brasil), juntando grupos diversos tanto no Posto Indígena de Peruíbe (Ladeira \& Azanha, 1988:9) como no de Bauru .

Os Mbyá, no entanto, continuavam sua caminhada, fazendo dos Postos Indígenas apenas locais de parada, até encontrarem os tekoá que buscavam, fosse uma aldeia onde já houvesse parentes morando, fosse um local indicado por alguma divindade ao xamã, através de sonhos ou de visões, o qual muitas vezes tinha sido uma aldeia ocupada por parentes antigos. Dessa forma, com aldeias espalhadas por diversas áreas da porção Meridional da América do Sul, os Mbyá estabelecem uma gigantesca rede de parentesco, com constantes movimentações de indivíduos e grupos familiares.

Em meados dos anos 1980 os Guarani voltam aos temas acadêmicos descolados do viés da aculturação, mas não do culturalismo. As novas etnografias buscaram descrever as formas de viver e de ver o mundo, mantendo como horizonte a questão da religiosidade como resistência cultural já presente em Schaden $(1974[1954])^{1}$.

A partir dos anos 1990 os estudos sobre os Guarani voltam efetivamente para a academia, num crescente exponencial de produção de Dissertações, Teses e

\footnotetext{
${ }^{1}$ À exceção de "Araweté: os deuses canibais", de Eduardo B. Viveiros de Castro (1986), que realiza um trabalho de etnologia comparada entre os Tupi e os Guarani em diversas passagens da obra, cuja orientação é então o estruturalismo proposto por Lévi-Strauss.
} 
artigos especializados. Em um anexo desta Dissertação apresento alguns dados sobre essa produção acadêmica recente que tem os grupos Guarani como foco, nas mais diversas áreas do conhecimento. Também trago uma lista de Teses e Dissertações elaborada a partir da pesquisa bibliográfica. São mais de duzentas obras listadas, produzidas em instituições de ensino e pesquisa federais, estaduais e particulares, de 1980 até fins de 2007.

Este trabalho se insere no contexto atual da volta de um olhar mais atento da academia sobre os Guarani, e aqui especificamente sobre os Mbyá. Para muitos, é motivo de espanto e admiração a presença de grupos indígenas no "olho do furacão", em plena megalópole paulistana.

De fato, é intrigante a presença. Os moradores indígenas do Jaraguá são classificados como "índios urbanos", ocupam uma área oficialmente reconhecida como Terra Indígena e demarcada e matém o uso de outras áreas que ainda estão em processo de demarcação. As pessoas que vivem na aldeia têm o cotidiano em grande medida tomado pelos assuntos internos, suas histórias pessoais as remetem aos vínculos com outras aldeias e suas expectativas encontram assento nos vínculos que produzirão entre si. No entanto, não são alheios às relações que se estabelecem com os não índios, também cotidianas, e que são parte de seu passado e, bem o sabem, serão parte de seu futuro.

Tem sido um desafio para todos os envolvidos na questão indigenista o aprendizado de uma convivência com as diferenças baseada na aceitação e no conhecimento mútuo. O Estado Nacional e seus agentes/representantes têm grande 
dificuldade para tornar minimamente inteligível a existência de uma sociedade cuja continuidade independe de fronteiras (daí as expressões "os Guarani de São Paulo", "os Guarani do Paraguai”, “os Guarani de...”). Tem-se a impressão de que se usar a expressão “os Guarani em São Paulo”, mesmo que para dar apenas uma referência geográfica ao contexto, significa que se apenas "estão em", futuramente podem não estar, o que leva à idéia de nomadismo. Mas há casos em que certos agentes e instituições do Estado reconhecem as relações que se estabelecem entre os Mbyá para além das áreas demarcadas. Por exemplo, pela passagem de linhas de transmissão de energia, com a construção de enormes torres e delimitação de uma área de segurança no entorno, foram definidas medidas mitigatórias não apenas para as aldeias Mbyá no bairro de Parelheiros, Zona Sul de São Paulo, por onde tais linhas passam, mas também para as aldeias do Jaraguá, cuja inclusão se deu pela ação tanto dos próprios índios como pela paciente e pedagógica intervenção do Centro de Trabalho Indigenista (CTI). Também no caso da construção do Rodoanel Mário Covas, próximo às aldeias de Parelheiros, o Jaraguá foi incluído como atingido e, portanto, beneficiário da compensação. Tanto o Ministério Público Federal em São Paulo quanto as empresas envolvidas compreenderam a necessidade da inclusão da T.I. Jaraguá como beneficiária das medidas, uma vez que qualquer evento mais grave, que afete a vida das pessoas do Tekoá Tenondé Porã e do Tekoá Krukutu as aldeias que mais sentiriam seriam as mais próximas tanto em termos geográficos quanto em termos de parentesco (o Tekoá Ytu e o Tekoá Pyaú do Jaraguá). Entender que as aldeias e as pessoas que nela vivem não são formam uma totalidade exclusiva é uma das dificuldades para esses agentes. Um terceiro exemplo é o caso do Centro de Educação e Cultura Indígena (CECI), criado na gestão de Marta Suplicy na prefeitura de São Paulo. A coordenadora 
pedagógica, única não índia que acompanha a administração da escola, trabalhou arduamente para que o município reconhecesse o estatuto que foi produzido pelos moradores das aldeias, o qual reconhecia, entre outras coisas, que toda a aldeia é espaço de aprendizagem (e não apenas os limites da escola), uma vez que muito do que deve ser aprendido (do ponto de vista dos índios) não é e não deve ser ensinado na escola. Limites, jurisdições, fronteiras, são conceitos que os Guarani não ignoram, ao contrário, conhecem muito bem sua aplicação pelos não índios. Entretanto, não abrem mão de sua própria forma de organizar o mundo, tornando-o inteligível a seu modo.

Assim, também eu na pesquisa de campo fui levado a outras aldeias. Mesmo as de Parelheiros, na Zona Sul da capital, são longe o suficiente para que a programação leve em conta o pernoite: usando o transporte público a viagem leva cerca de quatro horas, saindo do Jaraguá.

Mas as relações de parentesco me levaram a lugares mais distantes, como aldeias do Rio de Janeiro e do Paraná. As famílias que vivem no Jaraguá ligam-se a quase todas as outras aldeias, seja pela consangüinidade, seja pela afinidade. Além disso, há laços que se estabelecem pela ação xamânica, com a forte atuação do pajé e cacique da aldeia Tekoá Pyaú, José Fernandes, que atende a pedidos de pajelança (rituais de cura mais prolongados) e de participação nos rituais anuais de batismo das crianças (quando elas recebem ou confirmam o nome-alma recebido).

Minha presença nos oguatá (caminhar, andar, andanças), com José Fernandes e outras lideranças, assim como minha estada no Tekoá Pyaú, não 
dependiam de contribuições financeiras (ainda que, quando possível, elas ocorriam). A visita a parentes em outras aldeias é um momento muito especial para eles, onde laços dos mais diversos tipos são reforçados. Participar desses momentos é um privilégio, e uma honra o convite. Toda a situação favorável para minha inserção em campo se deve a um conjunto de fatores, dentre os quais as orientações da Profa. Marta Rosa Amoroso e a participação em um grupo de estudantes da USP, o qual se destacava no conceito que as lideranças tinham sobre os estudantes em geral. $\mathrm{O}$ Oim Porã ma Oré Rekó (algo como "melhorando nossas vidas") é um Grupo Interdisciplinar de Extensão Universitária, e tem como objetivo a atuação indigenista junto aos Guarani no Jaraguá. Sua formação incluía estudantes de arquitetura, ciências sociais, antropologia, geografia, psicologia, pedagogia e física. O diferencial dos participantes do grupo era a postura em campo: não se pretendia a aplicação de planos elaborados nos bancos da academia, mas o entendimento, a compreensão das necessidades apontadas pelos próprios moradores das aldeias. Havia, efetivamente, o risco de tornar-se apenas uma fonte de recursos, e realizar um trabalho assistencialista sem maior envolvimento. Mas essa postura de, antes de tudo, ouvir, era traduzida como um ato de respeito e, mais do que isso, como uma predisposição para se colocar no lugar do outro. Assim, ser membro desse grupo foi um importante fator para a aceitação de minha presença na aldeia.

As pesquisas que eventualmente algum membro do grupo deveria realizar eram comunicadas às lideranças, em reunião na opy, obtendo o aval com a palavra final do cacique. Assim, os Guarani sabiam que também escreveríamos sobre eles, da mesma forma como outros estudantes o fazem, no entanto, nossa atuação incluía, muitas vezes prioritariamente, a elaboração e o desenvolvimento dos projetos que as lideranças reunidas na opy definiam como necessárias. A clareza a 
respeito das nossas intenções no local visava evitar as desconfianças comuns nas relações entre estudantes/pesquisadores e os índios. Também estava claro o retorno que poderíamos oferecer, seus alcances e seus limites. E quase sempre a atuação indigenista antecedia a qualquer produção acadêmica.

Atualmente, diversos membros do Grupo de Extensão estão envolvidos com o processo de ampliação das áreas demarcadas para os Guarani em São Paulo.

Capítulo I apresenta dados históricos sobre a presença dos Mbya no Jaraguá a partir de meados do século passado. Descrevo a formação da aldeia Tekoá Ytu, alguns elementos de seu cotidiano e da trajetória de seus fundadores. Apresento algumas informações sobre a relação entre índios e colonizadores que tiveram na região do Jaraguá um importante palco, cujos ecos ainda fazem-se sentir.

O Capítulo II explora a formação da aldeia Tekoá Pyaú, traz dados etnográficos sobre o cotidiano, a religiosidade vivida na aldeia e elementos históricos sobre a trajetória das principais lideranças, cujas famílias são identificadas em gráfico anexo.

O Capítulo III faz um balanço bibliográfico do tema das estruturas de parentesco Guarani, o qual é colocado em discussão com os dados obtidos no Jaraguá por meio de trabalho de campo.

O Capítulo IV apresenta e discute os dados da pesquisa etnográfica tendo como foco as posições das lideranças e as relações de identidade e alteridades que se estabelecem entre lideranças e grupos. 
Na parte final, é trazido à tona o debate sobre a noção de tekó (o "modo de ser") dos Guarani, e propõe que o enfrentamento do tema rende soluções importantes para a compreensão das estruturas socioculturais desse grupo indígena.

Em anexo, uma lista de teses e dissertações produzidas sobre os Guarani, elaborada durante a pesquisa bibliográfica. São monografias produzidas pelas diversas disciplinas acadêmicas que tiveram esse grupo indígena como foco. A partir dessa lista é possível quantificar o exponencial aumento dos estudos sobre os Guarani, identificando quais as disciplinas e instituições de pesquisa vêm se dedicando ao tema nos últimos anos. 


\section{Capítulo I}

\section{A HISTÓRIA GUARANI DO JARAGUÁ}

\section{Introdução}

Neste capítulo apresento a história da ocupação da área do Jaraguá pelos Guarani a partir de fins dos anos 1950. A região é rica em informações históricas relacionando a presença indígena e a formação e o desenvolvimento da cidade. Os Guarani participam da história da região não apenas a partir da chegada dos europeus, mas desde que, em tempos imemoriais, travavam suas guerras contra os Tupi ou mesmo contra outros grupos guarani (pois que não formam uma "nação" unitária). Além das excursões de guerra que levavam os Guarani e os Tupi de um lado a outro do continente, as relações entre eles se estabeleciam também pela captura de guerreiros inimigos (os quais muitas vezes viviam por anos entre seus captores).

Também há que se fazer referências às grandes migrações descritas pelos primeiros europeus que aqui chegaram, as quais também trouxeram para estes lados da América do Sul incontáveis quantidades de aldeias, inteiras, populosas. Foi só então, após os primeiros contatos, que os Guarani, assim como outros grupos indígenas durante a colonização, vieram para cá trazidos à força, para a servidão nas missões ou para a escravização nas minas e plantações paulistas. Se a história desses povos já estava relacionada com estes lugares - que hoje conhecemos com nomes diferentes dos eram usados há mais de quinhentos anos -, também há que 
se afirmar que nossa história foi e continua sendo construída na relação que estabelecemos com eles.

Assim, se neste momento não é possível estabelecer uma relação direta entre as pessoas que moram hoje naquelas aldeias do Jaraguá, isso não significa que ela não exista. Reconstituir esses elos, no entanto, não é o foco deste trabalho, mas apresentar os resultados da pesquisa histórica e etnográfica realizada entre aqueles que hoje estão lá. 


\section{1 - A formação da aldeia Tekoa Ytu e o Parque Estadual do Jaraguá}

A fundação do Parque Estadual do Jaraguá, em 1961, representou um importante passo para a preservação do patrimônio histórico nacional ${ }^{2}$, pois implicou na proteção - mesmo que precariamente efetivada - de um local citado em fontes históricas desde o primeiro século da colonização. Ainda sob o clima das comemorações do IV Centenário de São Paulo, foi realizado naquele ano de 1961 um evento de inauguração com a presença do então governador Carvalho Pinto ${ }^{3}$. Para "dar um colorido especial para a fundação do Parque" (Monteiro, 2004:67) uma família de índios Guarani foi convidada para fazer ali uma aldeia: Joaquim, Jandira e seus filhos.

A manutenção de ocupantes "nativos" naquele espaço tinha objetivos mais pretensiosos do que a decoração de um evento. Historicamente importante não apenas pelas citações e descrições encontrados em textos desde há mais de quatrocentos anos, o local oferece, materialmente, uma imagem daquele passado remoto: os tanques de lavagem de ouro, construídos quando Afonso Sardinha comandava ali a mineração desse metal, em fins do século XVI. O local, por isso, era visto como portador de diversos signos caros a uma simbologia da "paulistanidade", cujo culto enaltecia a riqueza da terra, o trabalho e o bandeirantismo.

2 Em 1978, o Condephaat (Conselho de Defesa do Patrimônio Histórico, Artístico, Arqueológico e Turístico) pediu o tombamento do parque, o que ocorreu apenas em 1983. Em 1994, o Parque Estadual do Jaraguá foi tombado como Patrimônio da Humanidade pela Unesco, passando também a integrar a Zona Núcleo do Cinturão Verde da Cidade de São Paulo, Reserva da Biosfera.

${ }^{3}$ Carvalho Pinto foi integrante da Comissão Organizadora das comemorações do 400 anos da cidade de S. Paulo, em 1954. 
Depois que foi declarado "Ponto Turístico da Cidade de São Paulo", em 1946, o então chamado Morro do Jaraguá foi objeto de atenção de uma comissão instaurada em 1947, a qual deveria elaborar um projeto de intervenção para torná-lo um símbolo da cidade. Assim, surgiram propostas como a construção de um hotel, de uma capela ecumênica, de um monumento ao apóstolo São Paulo e de um museu para homenagear aos bandeirantes, o qual englobaria não apenas os tanques de lavagem de ouro, mas também um casarão que teria pertencido ao próprio Afonso Sardinha. As obras deveriam estar prontas até as comemorações do IV Centenário de São Paulo, em 1954, mas o projeto não saiu do papel, e assim permaneceu mesmo quando da inauguração do Parque Estadual, em 1961, ou quando o governador Adhemar de Barros ${ }^{4}$ destinou verbas para sua realização, em 1964.

Assim, o convite para que Jandira e Joaquim se transferissem com sua família para o Jaraguá estava inserido em um contexto que envolvia o culto a uma paulistanidade ufanista e a crença de que os índios, sendo "mais naturais", preservariam aqueles locais históricos em meio a um remanescente de mata atlântica. A mudança para o Jaraguá, no entanto, não se encerra no contexto dos eventos ligados à formação do Parque ou das ideologias subjacentes àqueles projetos. A conjuntura envolveu também elementos relacionados com as estruturas sócio-culturais dos Mbyá e com suas agências.

Jandira, a cacique do Tekoá Ytu no Jaraguá, conta que ela e seu falecido marido foram procurados por um membro da Sociedade Geográfica Brasileira (SGB)

${ }^{4}$ Foi o próprio Adhemar de Barros, então interventor federal em São Paulo, quem pediu para que a Secretaria da Fazenda adquirisse a área, em 1939. A última tentativa - também frustrada - de homenagear aos bandeirantes aconteceu na época das comemorações dos quinhentos anos do descobrimento, através de uma campanha chamada "Resgate do Projeto Morro do Jaraguá". 
para falar de uma área onde poderiam fazer suas casas e morar. Segundo a cacique, ele teria se sensibilizado com uma matéria publicada em jornal, a qual relatava a difícil situação de alguns índios que estavam sendo retirados de uma área da prefeitura, no bairro de Cidade Dutra, zona sul da capital paulista. Mas por que essa família não estava no bairro vizinho de Parelheiros, onde já haviam aldeias Mbya? Por que mudaram-se para o Jaraguá? Para responder a essas questões é necessário voltar um pouco no tempo. Aproveito então o ensejo para descrever alguns elementos das trajetórias de vida de Joaquim e Jandira, através dos quais, ao final, analisamos essas e outras questões. 


\section{2 - Alguns elementos das trajetórias de vida de Joaquim e Jandira}

Nascido em uma aldeia em Bagé, Rio Grande do Sul, Joaquim Augusto Martim migrou ainda criança com sua família para São Paulo. Ele contou ${ }^{5}$ que moravam próximos à fronteira com o Uruguai, para onde seu pai ia todos os anos em busca de trabalho junto às fazendas da região. Disse ele que antigamente era assim, cada pai de família deveria sustentar a mulher e os filhos, trazendo alimento para eles, não para a aldeia toda, mas só para a família.

O grupo com o qual Joaquim migrou era formado por diversas famílias e seu tio era o cacique. No caminho, ainda próximos à fronteira com o Uruguai, passaram pela aldeia na qual seu avô era o cacique e o nhanderu $^{6}$ (o xamã). Ficou intrigado com o fato de já estarem todos prontos para a viagem, partindo então no mesmo dia.

Joaquim lembra-se que estavam todos reunidos, e havia uns militares, vestidos de cáqui, dentre os quais um, que aparentava ser índio também. Ele pendurava uma medalha em cada pessoa. Tal medalha serviria para que pudessem fazer o caminho até São Paulo sem que precisassem dispor de recursos. Dessa forma, conseguiram estadias em fazendas, doação de alimentos e transporte de $\operatorname{trem}^{7}$. Joaquim afirmou que, muitos anos depois, descobriu que aquele benfeitor era Marechal Rondon.

${ }^{5}$ Depoimento gravado em vídeo pelo Centro de Trabalho Indigenista - CTI, s/d.

${ }^{6}$ Nhanderu é como se referem aos deuses. Nhanderu ete é como chamam ao deus criador, mas também usam o termo para se referir a Kuaray (ou Nhamandu) e a Tupã. No Tekoa Pyau dizem que, antigamente, quando os pajés tinham força espiritual para conseguir sua morada na aldeia dos deuses, eles eram chamados de Nhanderu Mirim.

${ }^{7}$ As antigas passagens de trem eram feitas de metal, um pequeno disco com um furo no centro (como algumas moedas chinesas). Talvez fossem as medalhas de que fala Joaquim. 
Até que pudessem tomar o trem em Passo Fundo (RS) fizeram diversas paradas, sendo acolhidos por prefeituras e fazendas particulares. Disse seu Joaquim que, num certo dia, havia uma agitação fora do normal. Foi feito um cercado onde colocaram as mulheres e as crianças protegidas por alguns $x o n d a r 0^{8}$. Os homens preparavam rapidamente seus arcos, flechas e tacapes, então "os índios da outra tribo vieram atacar, disse Joaquim, mas nossos índios já estavam preparados". Nesse dia, sua mãe foi levada e não puderam resgatá-la. Os feridos foram tratados e então seguiram viagem. Seu pai, que havia ficado na cidade de São Pedro (RS) para trabalhar, chegou à noite, quando tudo já havia acontecido. Joaquim, no entanto, ficou a partir de então sob os cuidados de sua tia materna.

O grupo, formado por algumas centenas de pessoas, seguiu viagem por trem e chegou a Bauru, interior do estado de São Paulo e de lá rumaram para Sorocaba a pé. Joaquim encontrava-se muito doente e ficou internado em um hospital. Não podendo partir, ele foi deixado ali por seus parentes, que rumaram para a aldeia do Rio Branco (em Itanhaém, litoral sul de São Paulo), com a promessa de buscá-lo assim que possível. Então, seguiram viagem o seu tio e "mais dois ou três caciques com a sua gente, acompanhando o nhanderu", seu avô.

Faço aqui uma pequena transgressão à narrativa para comentar esse fato. Ser abandonado pela família no hospital não é uma coisa muito comum entre os Guarani. Em São Paulo há o caso de uma neta de Karaí Poty que, segundo contaram algumas das lideranças da aldeia, teria sido internada para tratar de uma bronquite e, após esse período, foi proibida pelos médicos de voltar para casa. Agora, eles alegam possuir uma autorização judicial que também proíbe as visitas,

${ }^{8}$ Corruptela de "soldado". Função com direito de uso da força, quando necessário. Também usado para designar a função cerimonial de canto e dança dos acompanhantes do rezador nos rituais cotidianos realizados na casa de rezas. No caso das mulheres, o designativo é xondaria. 
inclusive aos parentes da menina. A alegação dos médicos, segundo os Guarani, seria de que os índios deixariam os mais fracos para trás para não se ter que carregá-los, e que seria da natureza dos índios desvalorizarem os mínimos cuidados com a higiene, deixando para que deus decida pela vida ou morte. Ao que parece, quando os médicos informaram aos parentes da criança o seu quadro de saúde e a possibilidade de óbito caso certos cuidados não fossem tomados, Karaí Poty (José Fernandes, cacique da aldeia Tekoa Pyau) teria declarado que, se ela morresse, seria porque deus assim iria querer independentemente de qualquer esforço que fizessem. Apesar de não ter afirmado em momento algum que não seguiriam as orientações médicas, essa fala teria sido tomada como declaração de intenção de abandono da menor. Além disso, comentam na aldeia que também haveria o desejo, por parte de uma das médicas, de adotar a menina. Fico pensando no quanto pode ter sido esse o caso de Joaquim, dada a pouco provável atitude de abando das crianças por parte dos Guarani Mbya.

Voltemos, então, a Joaquim. Após seu restabelecimento um casal de imigrantes alemães levou-o para morar com eles, tendo sido criado, segundo contou, com total liberdade, sem que nada the fosse exigido. Lembrava-se apenas do inconveniente de aquela família ter que se apresentar periodicamente à policia por serem estrangeiros. $O$ fato de estarem criando uma criança indígena "abandonada" certamente os ajudou a demonstrar suas boas intenções.

Quando estava com cerca de dezoito anos de idade o jovem índio reencontrou alguns de seus parentes em Santos, cidade para a qual partira em busca de trabalho. Ao ver um grupo de índios na cidade a que acabara de chegar, Joaquim sentiu o impulso de perguntar se eram Guarani e aonde moravam. Contou sua história e, assim, fez seus parentes se lembrarem da criança que havia mesmo 
ficado pra trás, em Sorocaba. Eles então o convidaram para conhecer a aldeia $^{9}$ em que moravam, a Rio Branco. Mas Joaquim não ficou logo com os parentes, e trabalhou em diversos lugares no estado de São Paulo como sítios, fazendas e em uma escola agrícola mantida por entidades evangélicas. Mudando-se para as proximidades da aldeia, passou a fazer parte de um grupo de música que se apresentava em bailes populares no litoral sul de São Paulo.

Segundo a cacique Jandira (FAU-USP:1992), seu encontro com Joaquim se deu em um baile na aldeia Aguapeú, Mongaguá (litoral sul de São Paulo). Lá chegando, foi convidada por Joaquim para dançar. Ele era um dos músicos do grupo que se apresentava. No mesmo instante pediu a mão da jovem índia em casamento. Ela disse então que foi instruída por seus pais a responder, nesse caso, que o pretendente deveria se apresentar a eles. No dia seguinte Joaquim foi à aldeia para falar com o pai de Jandira e a pedir em casamento.

Joaquim e Jandira moraram alguns meses na aldeia dela, mas segundo Jandira, ele não teria se acostumado com a vida na aldeia e, então, resolveu mudar-se com a família: Joaquim era constantemente solicitado para diversos trabalhos junto aos parentes de sua esposa. Mudaram-se para Itaquaquecetuba, em 1950, e depois para a Barragem (Parelheiros, zona sul de São Paulo), onde já viviam outras famílias Guarani (como a de Xapé, que era primo de Joaquim, e a de Ramiro, irmão mais velho de Karaí Poty, ambos primos de Jandira).

Joaquim, cuja história de vida levou-o a conviver por um longo tempo com não índios, tinha facilidade em lidar com a burocracia das instituições públicas, como hospitais, postos de saúde e delegacias. Assim, ajudava a quem precisasse ser

${ }^{9}$ Depoimento por Dona Jandira, em 2006, a Fabio, Adriana Queiroz Testa e Daniela Morita Nobre, membros do grupo interdisciplinar de extensão universitária "Oim porã ma oré rekó". 
encaminhado aos serviços públicos de saúde, ou às delegacias, nos casos em que crianças da aldeia se perdiam na cidade. Também aqueles que estavam apenas de passagem por São Paulo, e precisavam seguir viagem para o litoral norte, para o Rio de Janeiro ou para o Espírito Santo procuravam a sua ajuda. Muitas dessas pessoas eram parentes, próximos ou distantes, de Jandira, cujos laços de parentesco se estendem por uma grande quantidade de aldeias.

Mas então, um evento inesperado faz com que se rompessem as relações de Joaquim com os moradores das aldeias de Parelheiros: a morte de uma criança. Ela teria sido hospitalizada por problemas pulmonares, e seu caso foi acompanhado de perto pelo marido de Jandira. Não é incomum que se responsabilizem aos xamãs pela morte de seus "pacientes", assim, o lugar que Joaquim ocupava era também associado ao papel de alguém que produz/conduz a cura - 0 xamã. $A$ tensão que daí se seguiu foi um importante componente do contexto que causou sua mudança para Cidade Dutra, bairro próximo a Parelheiros.

No entanto, os laços de parentesco de Jandira continuaram direcionando as pessoas para ela e seu marido. Assim, além de continuar a facilitar o acesso aos serviços públicos dos quais os visitantes necessitavam, o casal passou a receber também pessoas que, por quaisquer motivos, tivessem saído de suas aldeias. Muitas vezes eram casos de conflito, cuja solução, para se evitar a violência, implicava na saída de uma das partes envolvidas. Esses "degredados" encontravam abrigo temporário junto a Joaquim e Jandira.

Mas o local que ocupavam em Cidade Dutra pertencia à prefeitura, que resolveu utilizá-lo e, assim, tirar de lá seus moradores. Esse evento, assim como a difícil condição de vida no local foram motivações importantes para a mudança dessa família Mbya. 
A constituição efetiva de uma aldeia no Jaraguá, no entanto, não foi imediata. Após terem recebido o convite do membro da SGB, Joaquim e Ari, que é seu filho mais velho e enteado de Jandira, fizeram diversas visitas ao local para só então concluírem pela mudança. As características do Jaraguá como a topologia, a fauna, a vegetação, o clima, as nascentes de água e o afastamento da área urbana foram decisivas para aceitarem o convite. 


\section{3 - Formação, características e cotidiano da aldeia Tekoa Ytu}

O ponto de vista privilegiado neste trabalho tem lugar junto às lideranças da aldeia Tekoa Pyau, na qual Karaí Poty é o cacique. Assim, a aldeia mais antiga, a Ytu, onde a cacique é Jandira, foi abordada na pesquisa de campo de forma menos intensa e por isso algumas questões não se tornaram objeto de investigação - pelo menos não a tempo de serem aprofundadas e incluídas neste trabalho final. Refirome, por exemplo, à possível presença dos Guarani do litoral naquela porção noroeste da capital, junto ao Pico do Jaraguá, antes da formação das atuais aldeias.

A primeira pista a esse respeito foi levantada por Inês Ladeira (1988:31), segundo a qual Joaquim mudou-se com sua família para um local onde um primo seu, o Guarani Nhandéva André Samuel dos Santos, já havia morado. Na pesquisa de campo, pude coletar algumas informações indicadoras da possibilidade do local já haver abrigado anteriormente a outras famílias Guarani. A abordagem in loco desse tema, no entanto, era difícil de ser realizada, tanto por razões cosmológicas como sociológicas, e exigiria que boa parte da pesquisa se dedicasse a ela. Há o fato de que todos aqueles dos quais se falariam já faleceram, o que causa incômodo aos entrevistados. Falar sobre os mortos tem várias implicações, geralmente associadas ao sentimento de saudade, como a possibilidade do espírito do falecido querer voltar para rever seus parentes, ou dos vivos serem tomados pela tristeza, a qual é relacionada a graves enfermidades espirituais. 
Além disso, o assunto remete a diversas relações conflituosas. Por exemplo, o fato de que André era primo de Joaquim, e portanto relativo à "aldeia de baixo"10 (Tekoa Ytu), tornava o tema pouco interessante, no mínimo, para os moradores da "aldeia de cima" (Tekoa Pyau). Mas também havia problemas para a abordagem do assunto no Tekoa Ytu, do qual se esquivavam discretamente. Nesse caso, as relações de identidade e alteridade que a questão envolvia eram outras: o fato de que André era Nhandéva poderia não ser um bom elemento constante da origem da aldeia, pois há o receio de que outros que não os Mbya reivindiquem sua precedência no local. É o que explica a dificuldade em descobrirmos ${ }^{11}$, finalmente, que uma descendente de André mora ainda na aldeia. Tal descoberta, no entanto, não ocorreu a tempo de ser investigada para este trabalho, e a moça não tinha outras informações sobre seu avô além de que ele vivia na região antes da chegada de Jandira e sua família. Assim, aproveito para esclarecer que quando me refiro aos Mbya no Jaraguá, estou falando precisamente de seus atuais moradores, sem, no entanto, reduzir a eles a história da presença dos Guarani na região.

O cotidiano na aldeia Tekoá Ytu, em suas primeiras décadas, era muito próximo do cotidiano vivido nas demais aldeias guarani. Os filhos mais velhos, casados, eram responsáveis por prover o alimento para suas respectivas famílias. Não tendo se acostumado ao trabalho formal, principalmente pela relação de subordinação a um chefe juruá, todos passaram a realizar trabalhos autônomos, informais e temporários, como serviços de alvenaria, pequenos trabalhos de

10 "Aldeia de baixo" ou "Aldeia de cima" são referências usadas pelos próprios moradores, em geral, quando se está falando uns sobre os outros. Os visitantes (não índios), entretanto, devem se referir às aldeias pelo nome que elas receberam. Alguns elementos das oposições entre o Tekoa Ytu e o Pyau serão discutidos neste trabalho.

${ }^{11}$ Tal questão em particular não foi objeto de investigação apenas desta pesquisa, mas também do grupo que tem apoiado aos Guarani no processo de demarcação de suas áreas. 
marcenaria e de eletricista em residências da região ou, o que foi mais comum, produzindo remédios com ervas medicinais e artesanato para vendê-los na "cidade" (o centro de São Paulo) ou nas áreas centrais dos bairros próximos.

Pequenas roças eram mantidas no entorno da aldeia, como na área onde hoje está o Tekoá Pyaú e em outras áreas que atualmente são lotes murados. Além de alimentos como o milho, a batata doce, a mandioca, também cultivavam plantas para fabricação de artesanato, como a que fornece as sementes chamadas "lágrimas de nossa senhora" e o cipó imbé (que ainda pode ser visto cobrindo árvores por detrás dos muros de onde hoje é um sítio).

$\mathrm{Na}$ região havia apenas sítios, chácaras e muitas áreas não ocupadas, devolutas, pertencentes à União, as quais foram sendo nas décadas seguintes loteadas e comercializadas. Também não havia sido construída a rodovia dos Bandeirantes, local para onde se estendia o remanescente de mata atlântica que caracteriza o Jaraguá. $O$ pequeno Ribeirão das Lavras, que corre junto à aldeia, fornecia os peixes que a família pescava, e a mata, no entorno do Parque, abrigava pequenos animais com os quais complementavam a alimentação. Karaí Poty visitou sua prima Jandira diversas vezes depois que ela se mudou para o Jaraguá. Ele rememora as andanças pelas matas que cobriam uma extensa área, acompanhando Ari, filho mais velho de Joaquim, caçando tatus e cotias.

Hoje, o ribeirão, que desce para a aldeia a partir de uma lagoa, tornou-se quase tão estéril quanto o rio Tietê. Em suas águas é despejado o esgoto das diversas construções que surgiram no entorno, poluição que tem também a colaboração do próprio Parque, a partir da estrutura criada para a visitação turística (banheiros, lanchonetes e prédios da administração). Diversos projetos que visavam à descontaminação e conservação das águas do Parque do Jaraguá já foram 
propostos, mas nenhum deles foi concretizado. A cidade foi se aproximando da aldeia com o passar dos anos e tomando o espaço de uso dos Guarani ${ }^{12}$.

A religiosidade na aldeia Tekoa Ytu era tão complexa quanto nas outras aldeias Mbya. Como discutirei nos próximos capítulos, a diversidade de elementos constituintes das relações de identidades e alteridades Mbya está também relacionada com a sua espacialidade, ou seja, com a sua noção própria de espaço e a relação que com ela estabelece. Assim, é necessário que a generalização em frases que começam com "os Mbya são..." seja bastante cuidadosa. A pluralidade de locais nos quais um Mbya pode viver ao longo de sua vida coloca-o em relação com alteridades igualmente plurais. Dessa forma, os elementos de identidade observados sob o ponto de vista dos indivíduos devem levar em conta não apenas o complexo de relações imediatamente observáveis no local em eu se encontram, mas também as relações que participaram da formação de sua história de vida.

No Jaraguá, Joaquim declarava-se evangélico, pois passou parte da infância e da adolescência morando com uma família de alemães protestantes em Sorocaba. Segundo Jandira, esse foi o motivo para a oposição do marido à construção de uma opy ("casa de rezas"), assim como ao uso do petyngua ("cachimbo" para fumo de tabaco) na aldeia.

Logo que se mudou para o Jaraguá, o então cacique participou de algumas atividades de diferentes denominações evangélicas, como cultos e pregações que estes realizavam em praças públicas. Muitas dessas participações eram fruto das relações que mantinha com seu primo André, que também era evangélico e o

12 Uma infinidade de novas ruas, avenidas, casas, conjuntos habitacionais e indústrias surgiram a partir dos anos 1970, levando a aldeia a conviver com o adensamento populacional, tráfego intenso de automóveis, a criminalidade, enfim, todos os problemas que afetam aos demais moradores da metrópole. Trato da transformação do bairro á frente. 
visitava quando pastores de sua igreja faziam cultos naquela região. No entanto, Joaquim não praticou proselitismo junto a seus filhos e netos para tentar convertêlos, deixando-os livres para escolherem a que religião seguiriam. Também não era constante a sua presença nos cultos, mesmo naqueles realizados na aldeia por pastores visitantes.

Jandira também manteve vínculos com seus parentes através da religiosidade Assim, sempre que possível ela levava alguns de seus filhos, e depois seus netos, à aldeia da Barragem para participarem dos rituais na opy - Joaquim não oferecia resistência a isso. Também o apoio que Ihes oferecia através de Joaquim generosidade característica das lideranças principais de uma aldeia Mbya reforçava esses vínculos.

Desde a estada em Cidade Dutra, como foi dito, Jandira e Joaquim intermediavam o trânsito das famílias que vinham do Sul do país para as aldeias de São Paulo ou que pretendiam seguir adiante. Além disso, como afirmou Inês Ladeira, "eram chamados a intervir - fazendo-o com eficiência - nos casos de internamento hospitalar, obtenção de documentos e nos casos de desaparecimento de crianças Guarani, na cidade" (idem, ibdem). A acolhida de pessoas e famílias que houvessem entrado em conflito em suas aldeias de origem, dando-Ihes morada por algum tempo, também era uma característica do Tekoa Ytu. Esse papel tem grande importância na organização social Mbya, pois o conflito deflagrador do rompimento das famílias também contribui para o fortalecimento delas, afinal, a quebra de uma família extensa é oportunidade para que outra família extensa se beneficie absorvendo novos membros, sejam parentes ou agregados ${ }^{13}$. Dessa forma, as

${ }^{13}$ O termo "agregados" aqui empregado se refere aos laços estabelecidos por uma família extensa com pessoas ou grupos familiares com os quais não existem laços de parentesco, nem necessariamente se tornam afins. Trato dessas questões mais à frente, no capítulo III. 
práticas adotadas pela aldeia Tekoá Ytu são mais um elemento a contribuir para a mobilidade, que é uma característica da estrutura social e da cosmovisão dos Mbya.

A postura de Joaquim em relação aos seus parentes e aos de sua esposa sustentou seu lugar de cacique da aldeia, e o ajudou a ganhar o respeito dos índios das outras aldeias. A generosidade com que os recebia era uma evidência do quanto estava próximo do ideal de liderança, característica do tekó, o "modo de ser guarani”. Mesmo após os conflitos causados pela morte da referida criança, no início dos anos 1960, continuou sendo procurado por aqueles que necessitavam resolver questões médicas ou burocráticas, como obtenção de documentos.

Por uma triste ironia, sua atuação a favor dos que procuravam seu auxílio, inserindo-o de forma ativa na rede de parentesco guarani, foi exatamente o que contribuiu para que seus filhos se afastassem dessa mesma rede, casando-se com não índios. Segundo depoimento de Cora, filha de Jandira, ao levarem parentes doentes para a aldeia, tanto para encaminha-los a um hospital, quanto para que se recuperassem (pois nem sempre ficavam internados), as crianças foram expostas a todo tipo de males. Ao notarem que as crianças da aldeia estavam perigosamente doentes, estudantes de medicina se mobilizaram para conseguir que elas ficassem internadas em casas de repouso, após passarem meses em hospitais. Assim, teriam vivido fora da aldeia de três a oito anos, em locais separados. A uns mais, a outros menos, o contato cotidiano exclusivamente com não índios levou a abandonar o uso da língua guarani. Voltando do longo tratamento, já não falavam a língua materna, passando a estudar nas escolas públicas da região. Mais tarde, alguns deles fizeram cursos profissionalizantes, como de eletricista, técnico em eletrônica, ou simplesmente concluíram o ginasial. Os rapazes passaram a trabalhar em empregos regulares. Tanto os filhos quanto as filhas de Jandira e Joaquim mantiveram círculos 
de amizades fora da aldeia (que na época era ocupada apenas por sua família), e casaram-se com homens e mulheres não indígenas. Esse fato é, hoje, um marcador diacrítico fundamental nas relações de identidade e alteridade entre as duas aldeias do Jaraguá.

$\mathrm{Na}$ época, Joaquim e sua esposa fizeram um grande esforço para que seus filhos casassem com índios Guarani, desaprovando seus encontros com os juruá. Percebendo que seus filhos poderiam vir a se casar com não índios, Joaquim criou uma regra segundo a qual quem se casasse com juruá deveria morar fora da aldeia, mas não conseguiu implementa-la de fato.

Essa postura poderia revelar uma aparente ambigüidade, pois ao mesmo tempo, segundo depoimentos coletados no trabalho de campo, ele fazia questão que seus filhos compreendessem bem e falassem o português, tendo pedido a alguns deles que se dirigissem a ele apenas nessa língua. Infelizmente, já não é mais possível saber o que pretendia, pois não discutiu essa questão com outras pessoas.

No entanto, um comentário seu a Karaí Poty, ainda nos anos 1960, permite que especulemos uma possibilidade. Segundo o cacique do Tekoa Pyau, Joaquim disse-lhe que seus filhos deveriam conhecer bem a língua do juruá, pois se soubessem apenas o guarani eles não seriam nada.

"[...] me lembro que o finado Joaquim falou assim 'ah, é, quero que meu filho estuda, não deixo falar no guarani e não sei o quê', então, [são] que nem juruá. Porque, não podem falar mais [em guarani] porque estão na cidade, estudando. Vão falar agora lá... nossa língua? Isso foi assim, por isso que não falam. Depois que cresceu quer falar? Não...”.

É interessante notar que, na aldeia onde Karaí Poty é hoje o cacique, o conceito de "conhecimento" figura entre a série de conceitos definidores da categoria "liderança", e pode englobar a instrumentação obtida através da educação escolar. 
Sendo possível apenas especular sobre a questão, reflito, não teria sido esse o intento de Joaquim: fortalecer a posição de sua família em relação às outras famílias Mbya, dando condições a seus filhos para que se destacassem nas relações com os juruá e, portanto, na obtenção de recursos para aldeia? Nos próximos capítulos faço algumas reflexões sobre esse lugar da idéia de "conhecimento" tendo como ponto de vista o lugar das lideranças do Tekoa Pyau.

Hoje, os netos de Jandira, que se declaram como a "terceira geração" da aldeia, realizam um movimento de resgate do que consideram importante para sua "guaranidade", envolvendo não apenas o aprendizado da língua, mas também a reprodução dos elementos da religiosidade como o uso do pytenguá (o chachimbo guarani), a participação cotidiana nos rituais da casa de rezas e o aprendizado que essa participação implica. Além disso dizem, com certo orgulho, que quase todos os netos de Jandira buscaram "casamentos intraétnicos", casando-se com Mbya de outras aldeias. Se, de fato, aquele era o plano de Joaquim, ele pode estar se realizando agora, através de seus netos.

As áreas das aldeias do Jaraguá eram contínuas até a construção da rua Comendador José de Matos, na década de 1980. O espaço onde hoje é o Tekoa Pyau era utilizado não apenas para pequenas hortas, mas também para moradias, como a de Eunice, filha de Jandira, além das que eram construídas para receber aos Guarani que transitavam entre aldeias ou necessitavam de tratamento médico em São Paulo. Nesse local também havia umas poucas casas de não indígenas, construídas no início dos anos 1990 sem que houvesse conflito. Dentre eles, porém, havia um homem que tempos depois se declarou caseiro do "verdadeiro" dono da área. Nessa época, após a morte de Joaquim, a atenção de Jandira estava voltada para a campanha que iniciou visando promover a construção de uma opy no 
Jaraguá: obteve apoio de setores da igreja católica, de empresários da região (que fizeram doações), e da imprensa, que fez a divulgação da luta da cacique.

Mas Pereira Leite, o tal "verdadeiro dono" logo apareceu, e se disse disposto a ceder o uso de "seus" lotes aos Guarani, desde que não construíssem mais casas. As declarações de Jandira a esse respeito (assim como sobre Fausto Ribeiro de Barros, da SGB) vão ao encontro da observação de Inês Ladeira, segundo a qual é “comum considerarem 'protetores' os juruá que se dizem 'donos' do lugar e que 'permitem' sua ocupação por parte dos índios, pretendendo usar os Mbyá para legitimarem suas posses" (Ladeira \& Azanha, 1988:24).

Com a valorização dos imóveis por causa do crescimento demográfico na região noroeste de São Paulo, nos anos 1990, os pretensos donos começaram a pressionar os Mbya para que desocupassem a área (onde hoje é o Tekoa Pyau). tom das ameaças era crescente, deixando bastante preocupados os moradores da aldeia.

Em meados dos anos 1990 Karaí Poty e sua família mudaram-se para o Jaraguá. Sua experiência com a questão fundiária dos Guarani o credenciava plenamente para esse auxílio, pois desempenhou importante papel, ao lado de outras lideranças Mbya, na organização das ações pela demarcação das terras ocupadas pelos Guarani.

Então, em 1996, Pereira Leite entrou com ação de reintegração de posse e, acompanhado pela Polícia Militar do Estado de São Paulo tentou a retirada dos moradores indígenas da área. Tendo sido avisado, o Ministério Público Federal em São Paulo acionou a Polícia Federal, que fez a retirada da Polícia Militar da área e iniciou processo contra Pereira Leite. 
Esse não foi um caso isolado, onde um grileiro se aproveita da presença de famílias indígenas para garantir a posse de terras com fins especulativos. Uma grande parte das áreas dos Guarani no Litoral de São Paulo sofreu a pressão desse tipo de ação: sabendo-se que se tratavam de terras devolutas ou da União, registravam a posse usando estes mesmos índios como prova de ocupação e usufruto, como se eles fossem empregados do pretenso proprietário.

Além desse caso, no Jaraguá, há o de Yasuiko Kugo, na aldeia Tenondé Porã, Otacílio Brás Lacerda, em Promirim, coronel Homero Santos, no Rio Silveira, o padre José, na estrada do Mboi-Mirim (Ladeira \& Azanha, 1988:24). Segundo Inês Ladeira, a atitude dos Guarani, em todos esses casos, foi de preservar-se dos conflitos, nem sempre tratados na esfera jurídica, mas por meio da violência. Dessa forma, ao aparecer um juruá declarando-se o dono do local e exigindo a saída dos índios, eles defendiam-se dizendo que a terra era de fulano de tal, e que era com ele que esse pretendente deveria discutir. E, mesmo considerando equivocada essa prática dos não índios de cercar um local e tomá-lo para si (pois a terra não pertence a qualquer humano, mas apenas àquele que a criou, Nhanderu Ete), entenderam como necessária a garantia legal de sua presença nos espaços que utilizavam. Assim, a partir da década de 1980, com o apoio de aliados não indígenas, trabalharam pela da demarcação dos tekoa em São Paulo.

Essa área, onde está o Tekoá Pyaú, estava sob jurisdição federal por conta do processo de demarcação iniciado nesse mesmo ano de 1996. No entanto, o Laudo Antropológico, peça essencial para a regularização fundiária e para garantia jurídica aos índios, foi considerado incompleto em um "parecer parcial" emitido por uma analista da Funai, a qual levantou questões realmente pertinentes, passíveis de serem respondidas em uma complementação do estudo. E esse deveria ser 
exatamente o próximo passo, não só pela indicação da analista, mas porque é essa a norma do encaminhamento desses processos. Mas então, por algum motivo desconhecido, seguiu-se um caminho diferente, e o pedido de ampliação da área, o qual incluía o pouco que restou dos espaços utilizados pelos Mbya no Jaraguá, foi negado por outro analista em um "parecer final".

Assim, o processo permaneceu "engavetado" até que, em 2007, uma nova gestão da Funai assumiu o compromisso de seguir as normas relativas à questão das demarcações e, então, encaminhar uma solução para a questão. 


\section{4 - Breves apontamentos sobre o bairro do Jaraguá e região}

As informações aqui apresentadas complementam a contextualização da presença dos Mbyá no Jaraguá. Elas formam o pano de fundo da história dessa presença no que diz respeito à sua relação com o entorno. São alguns dados sobre a história da expansão demográfica e da transformação da região a partir do fim do XIX. Ainda que seja apenas um rápido sobrevôo sobre essa história, possibilita uma noção sobre como se chegou àquela situação observada na imagem fotográfica que vemos das aldeias.

A influência política e econômica dos antigos produtores de café da região foi um importante fator para que fosse construída a estação de trem de Pirituba e de Taipas (que em 1940 passou a chamar-se Jaraguá), da São Paulo Railway, em fins do século XIX. A paisagem rural desse distrito se transforma pela construção/extensão da malha ferroviária.

Com o fim dos anos de ouro do café, a partir da crise gerada pela quebra da bolsa de valores de Nova lorque, em 1929, as grandes propriedades foram sendo vendidas e divididas em fazendas menores, sítios, glebas e lotes. Mas permanecia até então área rural do município, basicamente com produções de subsistência - em 1950, dos 2.543 habitantes apenas 701 eram considerados moradores de área urbana.

Segundo Pereira (2005:33-34 $\left.{ }^{14}\right)$ as indústrias tiveram dificuldade em estabelecer-se no Jaraguá por ser esta uma região montanhosa, com terrenos muito íngremes. O contrário teria se dado no eixo São Caetano-Santo André, com a

${ }^{14}$ As páginas deste trabalho disponibilizado na internet não estão numeradas, assim, sigo a indicação de numeração de página do programa Adobe Acrobat Reader utilizado para sua leitura. 
conjunção de áreas planas extensas, abundância de águas fluviais e a própria ferrovia, favorecendo ali a expansão industrial.

Na década de 1950, a região do Jaraguá era um prolongamento das periferias da Cantareira, como Perus e Taipas, sendo que estas últimas eram mais populosas por serem já áreas residenciais operárias. Essa situação se modificou a partir da década de 1960, com a instalação da indústria Voith, próximo à Rodovia Anhanguera. A empresa construiu um conjunto residencial para os funcionários, impulsionando a ocupação do Distrito. A área próxima ao Parque passa a ser mais densamente ocupada com a implementação de linhas de ônibus para atender aos moradores da região, ainda na década de 1960. Assim, segundo Pereira (idem:38)

"As ferrovias e a circulação rodoviária assumem um papel muito importante na expansão horizontal da cidade, pois esta engloba as áreas periféricas mais próximas das centralidades, gerando a valorização imobiliária destas, expulsando da região a população menos favorecida para áreas cada vez mais distantes dessas centralidades".

A partir da região central do Distrito de Pirituba e das imediações da estação de Taipas (Jaraguá) novos núcleos populacionais vão surgindo, cada vez mais à periferia, por causa da expansão imobiliária. O Distrito do Jaraguá é oficializado como um desmembramento do Distrito de Pirituba em 1964. Os ônibus, que antes faziam o trajeto do Jaraguá a Pirituba, passam a fazê-lo também diretamente ao centro da cidade.

A Rodovia Anhanguera, a Anchieta e a Dutra foram construídas em 1940, sendo que a principal via de acesso do Jaraguá à Anhanguera é, ainda hoje, a Estrada Turística do Jaraguá, onde se localizam as aldeias Tekoá Pyaú e Tekoá Ytu. Ao longo da Rodovia Anhanguera surgiram diversas indústrias nos anos 1980, e com elas ampliaram-se as ocupações irregulares no entorno através da especulação 
imobiliária. O mesmo ocorreu após a construção da Rodovia dos Bandeirantes na década de 1970.

Segundo Pereira (idem:39)

“[...] em pesquisa realizada por Jannuzzi (2004) sobre a projeção demográfica do município de São Paulo, alguns pesquisadores e especialistas afirmaram que a região que apresentará maior dinamismo demográfico será a área próxima ao eixo Bandeirantes e Anhanguera".

A especulação imobiliária tem grande participação no aumento da densidade da ocupação do Jaraguá. Além das empresas privadas, ligadas ao setor da construção civil, como empreiteiras e incorporadoras, houve a atuação de entidades que, em tese, não se constituíam como empresas privadas com fins lucrativos, mas que atuavam efetivamente com esse fim. É o caso do MTSTSP (Movimento dos Trabalhadores Sem Terra de São Paulo) ${ }^{15}$, o qual, segundo depoimento de moradores das aldeias, já teria enviado representantes para obter informações sobre a situação das áreas ocupadas pelo Tekoá Pyau e Ytu.

${ }^{15}$ Essa entidade tem como principal representante o advogado Marcos Zerbini, que teria se tornado vereador (PSDB) tendo a entidade como base de apoio. O MTSTSP foi responsável por loteamentos irregulares em diversas áreas de Pirituba e Jaraguá, inclusive nas proximidades do Parque do Jaraguá. A atuação dessa entidade é analisada por Pereira em sua dissertação de mestrado (2005). 


\section{5 - Elementos da presença indígena na região do Jaraguá e da história local antes das aldeias atuais}

Apresento aqui informações históricas mais gerais por dois motivos. Primeiro, porque a história do início da colonização foi o pano de fundo para a composição dos ideais que levaram, enfim, a se fazerem o convite para que uma família Mbya viesse a morar no sopé do Pico do Jaraguá, em meados do século passado história essa já interpretada a partir desses mesmos ideais, os quais louvavam a bravura, a coragem e o heroísmo do paulista em suas aventuras e descobertas através do bandeirantismo. E, depois, porque a presença dos Mbya, no Jaraguá ou em Parelheiros, não pode ser tratada como um fato isolado, descolado da história indígena em São Paulo - da mesma forma que não pode ser tratada como fato isolado em relação à mobilidade dos Mbya, histórica e estruturalmente relacionada ao grupo.

A história da região é rica principalmente no que diz respeito à relação entre exploradores/colonizadores e os povos indígenas. Além das lavras de ouro que empregavam mão de obra indígena, a região era o ponto de partida e chegada de expedições de captura de cativos para escravidão: as bandeiras. Nas aldeias, hoje, os Guarani comentam que não se livraram dessas companhias que ainda os cercam: de um lado corre a Rodovia Anhangüera, e do outro, a Rodovia dos Bandeirantes, nomes que os desagradam profundamente.

Segundo Monteiro (1994:61) com a proibição da captura e escravidão dos índios ainda em fins do século XVI, as chamadas "descidas" tinham como função oficialmente declarada a busca de locais onde poderiam ser encontrados pedras preciosas e metais, ou então a procura de escravos fugitivos, mas os objetivos reais 
seriam outros: a captura de índios para o trabalho escravo - a exemplo da empresa de Afonso Sardinha, de 1598, que alegou ter apenas o intuito de buscar "ouro e outros minerais", levando consigo "outros mancebos e mais de 100 índios cristãos" (Monteiro:idem; apud Atas da Câmara Municipal de São Paulo de 14/11/1598 e 24/11/1604).

Na década de 1580 o português Afonso Sardinha encontrou veios auríferos em morros algumas léguas a noroeste da vila de São Paulo, dentre eles, o Jaraguá. Mas foi apenas na década seguinte que se iniciaram os trabalhos de extração do ouro, pois os índios que viviam na região resistiram fortemente à invasão. Em 1592 Afonso Sardinha tornou-se "capitão da guerra contra os índios", por decisão da câmara municipal, e seus objetivos eram, além de proteger a vila dos ataques cada vez mais ousados, a captura de nativos para o trabalho escravo.

O historiador Afonso d'E. Taunay (2003:157) descreveu as atividades de mineração de Afonso Sardinha como apenas mais um de seus empreendimentos econômicos, pois ele também

"traficava escravos, vendendo índios moços a 3\$000 por cabeça, até para o Rio da Prata. De lá, encomendava diversos gêneros, como rendas, papel, medicamentos, facas fabricadas na Alemanha. Como capitalista, emprestava a pessoas de São Paulo e Santos, São Vicente e Rio de Janeiro".

E mesmo as atividades de mineração de Afonso Sardinha não se restringiam ao Jaraguá. Segundo Mello Nóbrega (1981:208) "Afonso Sardinha e seu filho mameluco de mesmo nome, ajudados por Clemente Álvares, mineiravam nas serras de Jaguamimbaba, de Jaraguá, Ivulturuna e Biriçoiaba”.

Os Guarani, chamados então de Carijó, que ocupavam as áreas ao Sul e Sudoeste de São Paulo até as regiões de Santa Catarina, Rio Grande do Sul e 
Uruguai, foram os alvos principais dessas bandeiras paulistas, as quais culminaram com os grandes ataques contra os Guarani entre as décadas de 1610 a 1640, e com as guerras contra a região do Guairá. Os bandeirantes paulistas, nesse período, eram ajudados principalmente pelos Tememinó, grupo Tupi que ocupava parte da região entre São Paulo e o Paraguai, e que eram inimigos dos Guarani já de longa data, e mesmo por outros Guarani, que também guerreavam entre si.

Os índios aprisionados eram distribuídos entre os colonos de São Paulo, que diziam cuidar deles e alforriá-los. Segundo Monteiro (1994:67) tal compromisso era um subterfúgio para a escravidão das mulheres e crianças indígenas (cujo trabalho se concentrava nas lavouras), e dos homens (que eram usados nas guerras para a captura de novos cativos). Os colonos que eram proprietários de minas, trabalhando com a exploração de metais, eram poucos. A maioria constitua-se de pequenos produtores agrícolas. Em ambos os casos, a mão-de-obra era formada basicamente por índios cativos escravizados, ainda que formalmente sua condição pudesse ser a de bárbaros convertidos.

O aldeamento de Barueri, constituído por um plano da administração colonial no início do século XVII estava estrategicamente próximo às minas de Voturuna e Jaraguá. Dom Francisco de Sousa (enviado pela Coroa portuguesa) pretendia integrar as atividades mineiras e agrícolas. Os índios desse aldeamento eram em sua maioria Guaianá e Guarani (idem:102-103), e estavam sob a guarda dos jesuítas ${ }^{16}$.

${ }^{16}$ As referências à extração de ouro da região do Jaraguá, segundo Mello Nóbrega (1981:209), podem ser encontradas até meados do século XIX. Mas não haveria, no entanto, quantidades suficientes do metal para que se atraíssem grandes quantidades de mineradores e bateadores, dando lugar a núcleos populacionais mais densos. A extração, apesar de constante, era escassa. 
Com o crescimento da economia paulista, houve concomitantemente maior necessidade de mão-de-obra. Assim, as áreas controladas pelos jesuítas representavam uma importante fonte de recursos. Isso levou ao ataque dos colonos à aldeia de Barueri, em 1632, dentre eles Raposo Tavares, expulsando dali os jesuítas e tomando para si os índios aldeados.

No início do século XVIII houve forte pressão por parte da Coroa para que os paulistas abandonassem o apresamento e o cativeiro dos negros da terra (Monteiro, 1994:215-220), com ameaças de multas pesadas aos infratores da legislação que garantia liberdade aos índios. Nesse período houve casos, inclusive, de escravos que alegavam serem descendentes dos Carijó, recorrendo ao Estado para reivindicar sua liberdade nos tribunais. Dentre os índios libertos pelos paulistas que cederam às pressões da Coroa houve aqueles que retornaram às áreas dos antigos aldeamentos, antes controlados pelos missionários religiosos. Essas propriedades passaram a ser administradas pela Coroa e, durante a vigência do Diretório dos Índios (1758-1798), contavam com uma população média de 1500 habitantes (idem, 2004:59). Com o fim do Diretório dos Índios, os aldeamentos da capitania de S. Paulo adentraram o século XIX sob uma forte política de integração à sociedade envolvente.

Nesse mesmo período aumentou a presença de cativos trazidos da África nas lavouras paulistas. A maioria dos escravos africanos, no entanto, foram enviados para as regiões das Minas (hoje o estado de Minas Gerais). Alguns paulistas se beneficiaram com a situação, pois São Paulo tornou-se um entreposto comercial nessa economia do escravismo - pelo menos até antes que os navios negreiros passassem a aportar na região do Espírito Santo. Aos agricultores paulistas, teriam restado duas opções: produzir e exportar mercadorias para a região das Minas, ou 
partir para o entorno delas e realizar lá os trabalhos agrícolas. Segundo Monteiro (idem:225) essa foi a opção de boa parte dos colonos. Aos mais pobres, sem condições de realizar essa transferência, restou a transformação das antigas plantações (principalmente trigo) em pastos para produção de gado, ou em canaviais para produção de aguardente.

Esse, aliás, foi exatamente o quadro encontrado por Luiz D’Alincourt, já no século XIX, apresentado em meio à descrição de sua longa viagem pelo Brasil. Ele fala da presença de um senhor cerca de setenta anos, chamado Tenente João Pinto Guedes, que morava "perto do morro Jaraguay, a três léguas da Cidade" (1975:45), desde mais ou menos o ano de 1800. Esse senhor vivia das plantações e da cana de açúcar, da qual fazia aguardente. Os moradores da região também criavam algumas cabeças de gado para produção de leite, que era vendido na cidade, e plantavam legumes, feijão e milho, do qual faziam a "jacuba"17, um alimento preparado com farinha de milho e água.

${ }^{17}$ Esse alimento, a jacuba, aparece em várias descrições da culinária regional de quase todo o país, principalmente nos trabalhos sobre o folclore brasileiro, sendo sua origem creditada aos bandeirantes paulistas, que em suas explorações pelo sertão fundavam vilas e disseminavam suas práticas; caminhos e cultura material herdados pelos tropeiros, aos quais também se creditam a dispersão da jacuba pelo Brasil. 


\section{Capítulo II}

\section{Tekoa Pyau: História e etNografia}

\section{Introdução}

Neste capítulo faço uma descrição histórica e etnográfica da aldeia Tekoa Pyau e apresento as lideranças indígenas que ali atuam a partir da descrição de alguns elementos de sua trajetória de vida. Os dados foram obtidos através de entrevistas livres, nas quais os interlocutores definiam o que seria importante relatar.

Em seguida, descrevo o Tekoa Pyau como o era no período em que lá estive durante o trabalho de campo. O seu espaço, os elementos que o compõem, e seu cotidiano. A partir dessas descrições analiso alguns elementos da estrutura social Mbya, tendo como foco as relações de parentesco, como a constituição de famílias extensas, a formação de grupos e as relações de identidades e alteridades a eles subjacentes.

Descrevo também alguns elementos indicativos da atuação das famílias aqui tratadas e de suas lideranças. Para distinguir as três famílias às quais me refiro, trato-as pelo sobrenome dos seus cabeças de parentela. A família Fernandes é a família extensa liderada por José Fernandes (Karaí Poty), cacique e xamã principal da aldeia. A família extensa liderada por Alizio Gabriel, presidente da associação indígena da aldeia, é chamada, assim, de família Gabriel. E os siblings Macena, com seus parentes, são chamados de família Macena. 


\section{1 - Elementos da trajetória de vida de lideranças do Tekoa Pyau}

Trato este tópico por "elementos da trajetória de vida" porque não há aqui a pretensão de se fazer uma "história de vida". Isso implicaria, creio eu, que a pesquisa elegesse apenas uma pessoa e a focasse em todos os aspectos possíveis. Assim, esta é uma breve apresentação dos personagens que se destacaram nas questões que dizem respeito à pesquisa.

Antes, um esclarecimento sobre a questão dos nomes múltiplos, como se verá no decorrer das transcrições. Os Mbya recebem seu nome guarani no Nimongaraí, ritual de nominação das pessoas que pode ser concomitante com os rituais de "batismo" do avati, o milho tradicional guarani, do bujapé avati ete - pão feito com o milho guarani, ou do kaa - a erva-mate. Mas também registram nomes em português nos documentos oficiais do Estado. Além disso, podem ser mais conhecidos pelo "apelido" do que por algum daqueles nomes, o qual pode fazer referência a alguma característica física (como a altura, o tom da pele) ou a características do comportamento (se agressivo, se excessivamente passivo, etc), muitas vezes relacionando tais características com um determinado animal ou planta.

Também é possível que a pessoa troque seu nome guarani, em geral como último recurso para a cura do que chamam "doença espiritual". Assim, é possível que uma pessoa seja tratada por diversos nomes diferentes. Procuro, ao longo do texto, tratá-los por apenas um de seus nomes para facilitar o desenvolvimento das narrativas. Um exemplo é o próprio cacique do Tekoa Pyau, Karai Poty, a quem também se referem como José Fernandes (nome e sobrenome em português), 
Kamba ("apelido") ou Guyra Pepó (nome pelo qual era chamado até a época em que morava na aldeia da Barragem, o qual consta nos documentos emitidos pela Funai).

No caso de Karai Poty, as variações presentes no texto se referem aos designativos de suas posições de liderança, como cacique, Xeramõe, pajé. São termos usados pelos membros da aldeia para se referirem a ele, aos quais também utilizo no texto. O termo xeramõe, como outros, tem mais de um significado: xamã, liderança espiritual da aldeia, avô (FF/MF), "os mais velhos". Assim, para me referir especificamente a Karai Poty, utilizo letra maiúscula no início da palavra (p.e. "o Xeramõe tem muita força espiritual”, é um comentário sobre Karai Poty, e não sobre os xamãs em geral, nesse caso, "os xeramõe"). Nomes próprios não são grifados em itálico, a não ser nos casos que se referem às divindades para diferenciá-las das pessoas portadoras desses nomes.

As narrativas aqui apresentadas são baseadas em depoimentos pessoais coletados ao longo do período em que estive em campo. Mais do que a reconstituição de uma história disposta em um tempo linear, a análise das narrativas das trajetórias pessoais teve como objetivo observar as relações sociais, mais especificamente as relações entre as posições de lideranças e grupos. Assim, não há nessas narrativas a preocupação em se reconstituir uma ordem cronológica coerente dos eventos, mas obter elementos que auxiliem a compreensão da organização social Mbya. 


\section{a) Karaí Poty (José Fernandes)}

José Fernandes nasceu em uma aldeia no Espírito Santo e foi trazido ainda pequeno para São Paulo, sendo então criado na aldeia do Rio Branco ${ }^{18}$. Nessa época, destaca o cacique, as crianças tinham muito medo dos não índios: “...com nove, dez anos de idade, tinha um fazendeiro lá que às vezes vinha chamar o pessoal pra trabalhar, corria do juruá, de medo"; e explica: "É porque os mais velhos falava 'não, é que os juruá é malandro, eles matam', aí, a gente corria”.

Aos quinze anos mudou-se para a aldeia do Rio Silveira ${ }^{19}$, permanecendo ali até os quarenta anos de idade. Aí, trabalhava como xondaro ajudando ao cacique Capitão Pedro, ao filho deste, Gumercindo, que assumiu o lugar do pai após sua morte, e aos demais caciques durante todo o tempo em que esteve na aldeia. Voltou para o Rio Branco, mas poucos dias após sua chegada, foi chamado para retornar ao Silveira por causa de um conflito com (policiais) "florestais", que foi resolvido após entendimentos com um sargento. De volta ao Rio Branco, trabalhou com os produtores de banana da região, tanto na colheita como no transporte por mar, pilotando o barco carregado das frutas.

Voltando mais uma vez ao Silveira, trabalhou em conjunto com o já então cacique Jijocó $^{20}$, tendo agora por objetivo a luta pela demarcação de terras. A partir

\footnotetext{
${ }^{18}$ Aldeia litorânea nos Municípios de Itanhaém e Mongaguá.

${ }^{19}$ Aldeia litorânea no Município de São Sebastião.

20 Índio pertencente ao grupo Tupi-Guarani ou Tupinambá (etnônimos auto imputados,
} chamados de Nhandéva, pela classificação etno-lingüística oficial e acadêmica), casado com uma índia Guarani Mbyá. É bastante respeitado e requisitado para os chamados "trabalhos espirituais", como pajelanças (rituais de cura) e nimongaraí (rituais de nominação). 
de então, Karaí Poty refere-se a esse tipo de trabalho como o mais importante que vem realizando, pois que é fruto de um chamado ou de um pedido de Nhanderu $^{21}$.

Nesse longo período em que morou na aldeia do Rio Silveira Karaí Poty estabeleceu uma relação de amizade e cooperação com os membros da família Macena (da qual trato mais à frente), e com os quais mantém até hoje alianças importantes.

Ao saber que seu primo Nivaldo havia chegado a São Paulo, vindo do Paraná, Karaí Poty mudou-se novamente, passando a morar na região de Parelheiros, extremo sul da capital paulista, por onde passam as rotas históricas ${ }^{22}$ dos Guarani, partindo do litoral, passando pela Serra do Mar, e indo em direção à cidade de São Paulo. Já havia então dois núcleos na área: a aldeia de Krukutu, e pouco mais à frente, a aldeia da Barragem, no caminho para Santo Amaro, bairro aonde iam para vender artesanato e o mais próximo que oferecia os equipamentos da cidade, como serviços públicos e comércio.

Era fim dos anos 1970 e início dos anos 1980, e Karaí Poty ali permaneceu, trabalhando junto com seu primo e outros moradores guarani da região para um pequeno produtor de hortaliças, Yasuiko Kugo - filho de migrantes japoneses que apresentava uma documentação de posse da área, apesar da ocupação Guarani Mbyá remontar a várias décadas. Após cerca de quatro anos trabalhando com as roças de mandioca, batata e hortaliças, iniciam-se as atividades de Karai Poty

${ }^{21}$ Nome dado às divindades celestes que enviam as almas para os corpos guarani que nascem na Terra, e que significa literalmente "Nosso Pai". É difícil saber especificamente a que divindade se referem quando usam o termo Nhanderu isoladamente. Às vezes especificam e falam por exemplo em Nhanderu Tenondé (ou Nhanderu Ete), Nhanderu Nhamandu, Nhanderu Tupã mas geralmente escondem dos não índios o politeísmo sob a referência genérica Nhanderu.

${ }^{22}$ Conf. Calixto, 1902:488-505. 
ligadas ao longo processo de busca de reconhecimento oficial da ocupação Guarani da área e da sua demarcação.

O contexto é o das campanhas pela demarcação das áreas guarani do litoral nos anos 1980, e envolveu diversas aldeias e diversos apoiadores não indígenas. Várias viagens foram feitas a Brasília, com recursos escassos, enfrentando dificuldades como fome e pernoites ao relento.

“É - diz o cacique - sofremos bastante os caciques. Nós fomos a pé, passava fome, tem algum lugar que só dá por a pé. Não tinha condição. Já hoje não, que pra ir já é mais fácil, a turma vai só no avião, vai no ônibus. Mas primeiro não. Eu, Jijocó, Altino, Nivaldo, Capitão Branco, esses nós sofremos bastante".

Nesse processo, Karaí Poty é convidado a tornar-se o cacique da aldeia da Barragem. Diz ele em depoimento: "aí [falaram] 'você fica cacique, que você que é mais forte, tem o espírito mais forte"”, ao quê respondeu "então está bom, eu aceito".

A demarcação das área de Tenondé Porã (Barragem) e de Krukutu envolveria ainda conflitos com grileiros e com a antiga rádio Tupi, que pretendia instalar-se ali. Com o apoio de entidades como o CTI (Centro de Trabalho Indigenista), a demarcação finalmente foi realizada pela Funai através de um convênio com o governo do estado de S. Paulo.

Mudou-se depois para a Terra Indígena Rio das Cobras, no Paraná, onde se encontram as aldeias guarani de Tapiti, Pinhal e Taquara, além de aldeias dos Kaingang, que formam a maior população. Ficou ali cerca de quatro anos. Ao final do primeiro ano, Karai Poty foi procurado pelo cacique kaingang que the propôs uma nova área para morar: "não, eu vou arrumar um lugarzinho pra você, você vai lá, lá na entrada da estrada que vem pra cá... Você vai morar lá e você vai tomar conta dos meus parentes lá, que tem muito bêbado lá, você dá um jeito neles”. Depois de 
um ano enfrentando problemas como brigas e alcoolismo, diz Karaí Poty que "todo mundo já gostava de mim, eu digo 'tá bom'”.

No tempo em que foi cacique na Barragem (denominada Tekoá Tenondé Porã, ou então Aldeia Morro da Saudade), Karaí Poty acionou a rede de contatos não índios, até então mobilizada no apoio à demarcação, para a obtenção gradual de melhorias para a aldeia. Mas, disse o cacique, com o desenvolvimento de tantos projetos, veio a desconfiança, por parte de algumas famílias, de que estivesse beneficiando-se dos recursos. Teria, então, explicado para as pessoas naquela época que "projeto não vem dinheiro na mão, governo que vem aí, vai fazer escola, projeto essas coisas, mas tem que mostrar pro juruá que está feito mesmo". Com o aumento da pressão por parte de algumas famílias, mudou-se com sua mulher e filhos para aldeia Tekoa Jaexa Porã, em Ubatuba, litoral norte de São Paulo. Permaneceu ali por três anos, com a certeza de que nunca mais voltaria a São Paulo, pela tranqüilidade do lugar e por sua localização, em plena Mata Atlântica. Mas, numa visita a sua prima Jandira, Krexu Mirim, cacique da aldeia Tekoá Ytu no Bairro do Jaraguá, na capital paulista, se viu convencido a mudar com a família para o local.

Primeiramente Karaí Poty descreve sua volta a São Paulo como fruto de um convite para morar em um lugar onde poderia "fazer uma rocinha" e viver tranqüilo. Mas em seguida revela que seu objetivo se relacionava mais uma vez com luta pela garantia da demarcação das áreas tradicionalmente ocupadas pelos Guarani. Dona Jandira vinha enfrentando problemas com grileiros que se apresentavam como proprietários de parte da área ocupada por seus familiares. Quando apareceram, tais grileiros se apresentaram como pessoas boas e dispostas a permitir o uso da área pelos índios, pois sentiam-se sensibilizados com sua situação. Em troca, os 
índios deveriam cuidar para não houvesse outro tipo de ocupação. Em meio aos constantes conflitos entre grileiros e supostos proprietários, não só na capital como nas aldeias do litoral, a posição dos Guarani foi sempre a de resguardo, inicialmente evitando ser mais um ator na disputa. Ao "dar permissão" para que os índios ficassem em "suas" terras, protegendo e zelando pelo patrimônio, esses especuladores davam às vezes contrapartidas, em forma de proteção e/ou víveres.

Mas então, a partir do início dos anos 1990, os supostos proprietários no Jaraguá mudam de postura, e passam a exigir a saída dos índios de "sua" área provavelmente motivados pelos interesses da especulação imobiliária que, nesse mesmo período, voltou seus olhos para aquela região da cidade.

Em meados dos anos 1990, Karaí Poty mudou-se para o Jaraguá, e depois de um ano sem qualquer conflito com não índios, apareceu novamente o suposto dono. O cacique contou que, num certo dia,

"chegou esse finado velho... João Leite, [que disse] 'não, isso aqui é meu; agora temos que fazer tudo, vamos lá pra delegacia'. Aí eu falei 'não, não vou'. Aí ele falou assim 'tem o papel da terra, que comprou aqui?'. Eu falei 'não, não tenho mas também sou... sou grande, viu'. Aí mostrei o meu documento de cacique. Aí ele foi embora."

João Leite teria ainda voltado mais duas ou três vezes, sem no entanto conseguir intimidar os moradores da área.

Tempos depois, um advogado desse suposto proprietário foi visto andando pelo local sem, contudo, haver pedido permissão a qualquer liderança da área: foi capturado. "Nós pegamos ele acho que foi umas seis, sete horas [da manhã], mais ou menos, ele entrou, aí pegamos. Ficou até cinco horas [da tarde] aqui”. A polícia militar foi chamada para "resgatar" o advogado, quando também chegou um delegado da polícia civil, que segundo Karai Poty, ordenou "solta esse rapaz que 
nós também vamos embora". "Não, não solta não", respondeu o cacique. O delegado ainda teria tentado argumentar, mas Karaí Poty finalizou a questão: “ ‘não, você que tem o direito de sair, se não sair vai ficar preso aqui também'. Falamos isso, todo mundo falou isso, então eles foram saindo devagarzinho. É, foi duro aqui”. Depois dos policiais militares e civis se retirarem da área, mas permanecendo no entorno, os Guarani chamaram aos policiais federais, que disseram, segundo o cacique, "'manda [o advogado] esperar mais um pouquinho que logo a gente está aí'. Já era... quatro horas [da tarde]... [risos]... Aí só cinco horas que eles chegaram".

O primeiro lugar no Jaraguá onde Karaí Poty construiu sua casa e as de sua família foi na área denominada Tekoá Ytu, já então demarcada e homologada, onde mora a maior parte da família de Jandira. Pouco tempo depois mudou-se para a área em frente, hoje denominada Tekoá Pyaú. Essa área, reivindicada pelos grileiros, era usada pela família de Jandira desde a época de sua mudança para a região, no início dos anos 1960, quando foi criado o parque estadual do Jaraguá. Era onde Joaquim plantava ervas medicinais, e plantas que forneciam sementes para artesanato, assim como continuaram fazendo seus filhos mais velhos. E Jandira, sempre que podia, plantava ali o milho tradicional guarani, da mesma forma que Karaí Poty e Rosa, sua esposa, passaram a fazê-lo.

Karai Poty conheceu Joaquim, falecido marido de Jandira, na aldeia de Mongaguá; visitava seu tio Alcides nessa aldeia quando o viu fazendo um convite a Joaquim para ali residir. Joaquim então conheceu Jandira, com quem casou. Mudaram-se para o Jaraguá, e Karaí Poty os visitava periodicamente. Ele saudosamente relembra as andanças e caçadas a tatus, pacas e outros animais nas matas da região, em companhia de Ari, filho mais velho de Joaquim, fruto de um 
casamento anterior a Jandira. Nesse tempo ainda não havia sido construída a rodovia dos Bandeirantes, e as vilas ficavam afastadas da aldeia.

Hoje, os parentes que Karaí Poty considera como mais próximos são os seus filhos e netos. Seus irmãos, mais velhos, faleceram todos: "parentes eu tenho bastante, mas o principal mesmo...". Assim, ocupa-se com a manutenção da unidade de seus descendentes, administrando conflitos e vinculando afins a compromissos com projetos para a aldeia.

Assim, nesta brevíssima apresentação de sua trajetória de vida, Karaí Poty mostra-se convicto de que se tem mantido no caminho mostrado a ele por Nhanderu: garantir a permanência do povo Guarani nesta terra. 


\section{b) Tupã Mirim (Alizio Gabriel)}

Alizio Tupã Mirim nasceu no estado do Paraná, no início dos anos 1960. Estudou em uma escola primária, construída na aldeia de Palmeirinha pela Funai.

“E meu tio [Gumercindo] era uma pessoa líder, né, uma pessoa que na época não era pajé ainda, o finado meu tio. E... ele ajudava os cacique lá, pajé, fazer organização, organização dentro da cultura indígena, não associação, de um trabalho, de fazer assim um projeto, não é assim. A gente fazia... nossa organização sempre tinha, mas que essa pessoa vai de casa em casa, pegar a pessoa, levar pra fazer mutirão. [...] comunidade indígena sempre tinha mutirão. Mutirão é um serviço comunitário. Então eles faziam um dia de trabalho pra uma família, um dia de trabalho pra outra família, assim vai indo".

No início dos anos 1970 a família de Tupã Mirim mudou-se para São Paulo, tendo seu tio Gumercindo à frente.

Recém chegados a São Paulo, Tupã Mirim e seu tio foram morara na aldeia da Barragem. Faziam a longa caminhada até o centro de Santo Amaro, bairro na zona sul da cidade, para vender os artesanatos produzidos por eles na aldeia da Barragem $^{23}$. Em um bar, em frente à igreja do Largo Treze, seu tio, alcoolizado, entrou em luta corporal com não índios, sendo então levado por policiais que por ali passavam. Tupã Mirim, com cerca de doze anos de idade, sem saber o caminho para casa e sem saber falar português, ficou sentado nas escadarias da igreja durante todo o dia. Tarde da noite, após a última missa, o padre, que já estava fechando as portas da igreja, notou sua presença. Tupã Mirim ainda chorava quando o padre the ofereceu ajuda. Sem entender o que aquele homem dizia, Tupã Mirim pensou que finalmente seria levado de volta para a aldeia, junto a seus parentes.

${ }^{23} \mathrm{O}$ local, que chamava-se Vila Guarani, passou a chamar-se aldeia da Barragem e, mais recentemente, Tenondé Porã. 
Entretanto, o padre o levou para sua casa, em Embu-Guaçu, e lá permaneceu por quatro anos.

Esse padre era o responsável pela construção de uma igreja na estrada M'Boi Mirim, também na zona sul da capital, onde havia uma pequena aldeia mbyá. Tupã Mirim, no entanto, preferiu naquele momento continuar morando na casa do padre. Estudava em Embu-Guaçu de manhã e à tarde ia com o padre para M'boi Mirim. Voltou um dia para a igreja do Largo Treze, acompanhando o padre, e ali reencontrou seu tio Gumercindo, vendendo artesanatos. $O$ padre convidou Gumercindo para construir uma casa na aldeia de Mboi Mirim, e ele aceitou. Depois, o próprio padre construiu uma casa para ele, junto à igreja, e mudou-se para lá com Tupã Mirim.

Depois de quatro anos morando com o padre, Tupã Mirim o ouviu pedir autorização a seu tio Gumercindo para levá-lo consigo a uma viagem para o exterior, da qual não haveria data para retorno. Seu tio concordou. No dia em que Tupã Mirim deveria ir para o aeroporto de Congonhas, tomou um ônibus para Santo Amaro, e de lá foi para a aldeia da Barragem. "Eu não sei se eu ia conseguir voltar de novo de lá dos outros países, ou ficava por lá", disse-me ele. Mas essa fuga ainda the rende algumas dúvidas: "Só que às vezes eu fico lembrando disso e fico pensando, né, se eu tivesse enfrentado essas coisa assim e aprender mais não cultura indígena, não sei se teria mais condição de ajudar meu povo".

Morou por dois anos na aldeia da Barragem quando então se mudou para a aldeia de Bananal, em Peruíbe (litoral sul do estado de São Paulo), onde tinha parentes. Após dois anos voltou para Tenondé Porã. Nessa época estava com cerca de vinte anos de idade. Foi quando casou-se com Tataxĩ, filha de Rosa e enteada de Karaí Poty. 
"Mas antes disso, eu já conhecia José Fernandes. Porque quando eu fui lá na Barragem, eu fui acompanhar assim... evangélico, né. Aí o Xeramõe também na época também acompanhava evangélico. Aí a gente ficava junto assim, domingo a gente ia pra igreja. Só que eu não tinha ainda casado com Tataxĩ. E na época Tataxĩ estava lá pra aldeia de... Ubatuba. Ela morava lá com a tia [FS] dela. Aí quando a tia dela faleceu, aí ela veio pra Barragem. Por isso que a gente casou".

Recém casados, mudaram-se para o Paraná, aldeia de Palmeirinha. Esse foi o único período em que Tupã Mirim trabalhou fora de uma aldeia, em lavouras da região. Voltaram para São Paulo, aldeia de Tenondé Porã, depois de quatro anos, e então tiveram seu primeiro filho.

"Aí... como eu era muito adolescente na época, eu, Tataxĩ também, e a gente não cuidava assim, a gente não sabia cuidar da criança, e eu acho que por isso a criança acabou falecendo. E a Barragem era bem afastado, era abadonado assim pela... pelo juruá na época".

Apesar do auxílio de uma religiosa que visitava a aldeia, a qual levou-os para um posto de saúde, e depois para um antigo hospital da Cruz Vermelha, na região de Congonhas, a criança não resistiu. Tataxĩ, com forte depressão, iniciou um tratamento que a faria deslocar-se diariamente da aldeia para o posto de saúde no centro de Parelheiros. Tupã Mirim sempre a acompanhava e cuidava dos procedimentos burocráticos como o preenchimento de fichas de atendimento.

Com o tempo, outras pessoas da aldeia que precisavam ir ao posto de saúde procuravam Tataxĩ, e ela pedia a Tupã Mirim que os ajudasse. Atendimentos, internações, explicação dos exames para os doentes, solicitação de explicações sobre as etapas do tratamento e tudo o que diz respeito ao trato com os profissionais de hospitais e postos (como diferenciar atendentes, enfermeiros e médicos) passaram a fazer parte da rotina de Tupã Mirim. 
Assim, por conta desse conhecimento acumulado, foi adquirindo reconhecimento e respeito dos moradores da Barragem, passando a representá-los nas reuniões com as instituições públicas de saúde. Planejou os encaminhamentos que não eram de emergência viabilizando (através da secretaria municipal de saúde) o transporte semanal dos pacientes até o posto de saúde em Parelheiros. Hoje a aldeia Tenondé Porã, assim como as aldeias do Jaraguá, conta com um posto de saúde dentro das áreas e carro da Fundação Nacional de Saúde, FUNASA, para os casos que necessitam de atendimento hospitalar.

Durante o período em que lideranças de diversas aldeias guarani se mobilizaram para conquistar o reconhecimento das áreas que ocupavam, Tupã Mirim acompanhou Karaí Poty nas reuniões tanto com nhandéva (traduzido como "nossa gente", "nosso povo", "nós Mbyá”, "nós Guarani”)"24, como com os juruá.

No entanto, quando Karaí Poty mudou-se da aldeia da Barragem, no início dos anos 2000, Tupã Mirim e sua família não o acompanharam. E até um ano após a volta do sogro a São Paulo, desta vez para a aldeia do Jaraguá, Tupã Mirim o reencontrava apenas por meio de visitas que fazia com sua esposa e filhos. Mas então, pela insistência de seus filhos e sua esposa, concordou em se mudem para o Jaraguá, onde já estava seu irmão Maurício, também genro de Karaí Poty.

Com o aumento do número de moradores na área, novas necessidades surgiram e outras se ampliaram. Decidiram-se então pela constituição de uma associação civil para representá-los junto às instituições públicas e privadas, buscando apoio e recursos para suprir suas necessidades. No primeiro momento, o

${ }^{24}$ Conceito que designa identidades diversas elaboradas na relação com alteridades diversas. Sua elasticidade, no entanto, parece ser limitada, pois não conheço registro do uso do termo nhandeva para se auto-referirem como "índios", mesmo quando em oposição ao termo juruá, o qual designa genericamente os "não índios". 
próprio Karaí Poty foi o presidente da associação, tendo em seus quadros lideranças já constituídas nas relações internas da aldeia, como Tupã Mirim, Verá Mirim (Wiliam Macena) e Karai Tataendy (Pedro Macena).

Os parentes de Tupã Mirim já haviam se mudado do Paraná para São Paulo formando, gradualmente, um núcleo de parentes próximos em torno dele. Com a mudança do cabeça de parentela para o Jaraguá o mesmo processo ocorreu, e mudaram-se os parentes para a nova aldeia. Hoje, apenas uma sobrinha dele permanece em Parelheiros, e dois tios estão em Palmeirinha, Paraná.

Atualmente Tupã Mirim é o presidente da associação, e tem seu tempo ocupado quase integralmente com as tarefas do cargo. Além de organizar a burocracia relativa à manutenção da associação, dos contratos de projetos e parcerias com instituições governamentais e não governamentais, é ele a pessoa procurada quando alguém precisa fazer ou renovar documentos, fazer certidões em cartório ou resolver pendências burocráticas junto à Funai ou Funasa - em muitas dessas tarefas é auxiliado pelo trabalho voluntário do advogado dr. Marco Antônio.

Muitas vezes Tupã Mirim se disse sufocado por essas responsabilidades, revelando seu desejo de voltar para onde nasceu, no Paraná, para rever lugares e pessoas. Mas acredita que isso não aconteceu porque Nhanderu ainda o quer por aqui. 
c) Os Macena: Karai Tataendy (Pedro Macena), Vera Mirim (Wiliam Macena) e Karai Mirim (Mario Macena)

A família Macena mudou-se para a aldeia de Ocoí, no estado do Paraná, em meados dos anos 1960, vindos de aldeias do Paraguai. O pai ${ }^{25}$ dos irmãos Macena trabalhava em fazendas na região próxima à fronteira com o Brasil. Das aldeias Mbya no Paraguai, recordam-se de nomes como "Tekoa Tadikanẽ" e "Tekoa Mbopikua"26. Seus laços de parentesco estendem-se por toda a região onde está a fronteira Brasil-Paraguai.

Mudaram-se para a T. I. Rio das Cobras, aldeia Pinhal, no fim dos anos 1960, e de lá para a aldeia de Palmeirinha, também no Paraná. Essa mudança foi motivada pela relação conflituosa com o antigo Serviço de Proteção aos Índios, SPI, e depois com seu substituto, a Fundação Nacional do Índio, Funai, criada em 1967. Segundo Pedro Macena, essa era "uma época em que o pessoal não podia mudar de uma aldeia pra outra sem autorização da... dos chefes lá, né... dos juruá, né? Aí começamos a ficar... até que saímos escondidos de lá. Saímos era noite. À noite saímos de lá e viemos pra Palmeirinha".

William é o mais novo dos irmãos, tendo nascido no Paraná no início dos anos 1970 e Mário é o mais velho, nascido ainda no Paraguai. Seus outros irmãos são, em ordem de nascimento, Maria, Antônio, Marilene, Conceição, Sérgio, Anita e Pedro.

Palmeirinha foi a última aldeia do estado do Paraná em que moraram, e depois de uma passagem pela aldeia do Bananal, em Peruíbe, litoral sul de São

${ }^{25}$ Quando houve resistência em se dizer o nome de uma pessoa já falecida, a qual é bastante sutil, tomei a atitude de não insistir.

${ }^{26}$ Tadi - um tipo de árvore e kanẽ - torta; Mbopi - morcego e kua - toca. 
Paulo, partiram para a aldeia Rio Silveira, em São Sebastião, litoral norte do estado. Mário, que já havia se casado, não seguiu viagem com seus irmãos mais novos, mudando-se para a aldeia Tenondé Porã, zona sul da cidade de São Paulo.

Em Rio Silveira, Sérgio e Antônio se casaram. A família Macena permaneceu morando nessa aldeia, na área chamada Boracéia, onde o atual xeramõe, Jejokó, já residia. O trabalho de vigilância da área era constante, pois além do conflito entre não-índios - supostos proprietários das terras onde se localizava a aldeia - também iniciava-se a mobilização dos Guarani pela demarcação das suas terras. Os rapazes formavam grupos de xondaro que acampavam na mata ou próximos a pontos considerados mais vulneráveis, à noite, e durante o dia outros grupos percorriam o entorno, sempre se revezando nessas vigílias. Em geral, elas aconteciam quando o cacique precisava viajar, ficando fora da aldeia por alguns dias.

Cerca de cinco anos após sua mudança para Boracéia, Pedro, William, e suas irmãs partem para a aldeia Tenondé Porã, onde reencontraram o irmão mais velho, Mário. Sérgio e Antônio, então cunhados do cacique Jijocó, permaneceram na aldeia Rio Silveira. Segundo Pedro Macena, o primeiro mesmo a mudar-se para Tenondé Porã foi seu cunhado, Manoel Lima (que viria a ser cacique dessa aldeia no início dos anos 1990), e, percebendo que havia condições de seus familiares mudarem-se para lá, chamou-os.

Além de Mário e uma das irmãs mais velhas, moravam já na Barragem Karaí Poty e sua esposa, Rosa. Esta é prima do pai dos Macena, assim, em certos momentos, é chamada de xejay ("tia"), a não ser por William Macena, que é seu genro e a trata sempre por xejaryi, que literalmente significa "minha avó", e é um termo de tratamento respeitoso dado às mulheres mais velhas. 
Chegando a São Paulo, trabalharam para um senhor descendente de japoneses que mantinha plantações de hortaliças e legumes, além de coleta e secagem de brotos de bambu, uma planta até então abundante em toda a região. Pedro Macena, com aproximadamente quinze anos de idade, acompanhou seu pai (e outros Guarani que moravam na área) nos trabalhos junto às roças desse senhor, a quem chamavam de "Sensei". Então, conta Pedro Macena "aí fomos morar no sítio do japonês. Meu pai trabalhava pro japonês plantando milho, repolho. [...] Ajudava a tomar conta, quando o japonês não tava lá aí ajudava a tomar conta do sítio dele. $\mathrm{O}$ japonês era bonzinho".

Mas então, ocorreu uma discussão entre o proprietário das roças e o pai de Pedro e William.

"Mas aí não sei o que que deu, o meu pai pegou uns cinco alqueire de milho, né, pra limpar pro japonês e trataram o preço de mil cruzeiros, na época, só que aí não sei o deu, no final meu pai limpou tudo, né, o milharal do japonês, e o japonês não quis pagar os mil cruzeiros. Queria pagar oitocentos. Aí meu pai ficou chateado com isso, aí pediu a conta, aí mudamos pra aldeia".

O clima na aldeia, no entanto, era tenso. A pressão da cidade sobre a área aumentava, pois com o surgimento de loteamentos irregulares aumentaram a população de não índios e os bares no entorno, facilitando o acesso à bebida. Os casos de alcoolismo na aldeia cresceram na mesma proporção. A reação a essa situação gerava ainda mais tensão, pois se baseava em um controle "policial" dos casos de bebedeira, através dos chamados "castigos" - surras dadas por um grupo de xondaro, liderados pelo cacique.

Mas esses casos de briga eram relativamente raros, segundo depoimento de Pedro Macena. A situação, no entanto, mudou radicalmente com a tentativa de instalação da antiga rádio Tupi. 
"Olha, briga mesmo foi quando começou a construção da antiga falida rádio Tupi, ali do lado do Tenondé, aquelas casas lá. Aí começou a vir peão ali pra trabalhar e começou a [?]. Aí começaram, também, a estuprar as mulheres... aí sim, aí começou a ter umas brigas, né. Aí o homem branco ia lá levar umas pingas já com outra intenção, dava pinga pras mulheres, levava as mulheres pro mato... Na época o Xeramõe [Karaí Poty] não era o cacique [...]".

William e Pedro Macena participavam de um grupo de xondaro formado por kunumingué (jovens rapazes, geralmente solteiros; traduzem o termo como "adolescentes") que tinha como tarefa principal o auxílio aos trabalhos cotidianos de Karaí Poty e sua esposa, especialmente nos pequenos roçados que cultivavam.

Depois que Karaí Poty tornou-se cacique na aldeia Tenondé Porã, os xondaro a ele ligados assumiram também tarefas ligadas à religiosidade do grupo. Assim que terminaram a construção da opy (a qual, segundo Pedro Macena, teria sido a primeira da aldeia) esses xondaro passaram a ser responsáveis por chamar as pessoas para participarem dos rituais, realizados cotidianamente logo após o pôr do sol. O aprendizado do mboraei e do jeroky, respectivamente do "canto" e da "dança" também fazia parte das tarefas cotidianas desses kunumingué. "A gente não conhecia muito - diz Pedro Macena - mas quando aprendia com o Xeramõe as danças, essas coisas, eu gostei bastante. Aí eu falava assim 'vamos pra casas de rezas"”.

Gradativamente os bailes (o "forró"), onde se consumiam grandes quantidades de bebida alcoólica, foram sendo esvaziados. Ao mesmo tempo, aumentava a presença de moradores da aldeia nos rituais da opy.

Já em fins dos anos 1980 Pedro e William envolveram-se nas discussões sobre a demarcação das terras Guarani, participando em nível local desse processo - as viagens para outras aldeias para reuniões e encontros contavam com a 
participação das lideranças mais velhas, principalmente dos caciques. Mário Macena, por sua vez, concentrava suas atividades na produção de artesanato e no auxílio a Karaí Poty nos rituais na opy.

Depois de passar dois anos na aldeia de Krukutu, William volta para Tenondé Porã, onde passa a participar da diretoria da associação indígena recém criada, na época em que o cacique era Manuel Lima. Pedro e Mário também estavam na Barragem nessa época, assim, nenhum dos irmãos Macena acompanhou Karaí Poty quando este saiu de Tenondé Porã no final dos anos 1990.

Mário Macena logo mudou-se para o Jaraguá quando o Xeramõe retornou a São Paulo, mantendo suas atividades ligadas mais à religiosidade do que às relações com os juruá e seus projetos. William acompanhou seu irmão mais velho no ano de 2000.

Nessa época os moradores do Tekoá Pyaú enfrentavam problemas que dificultavam sua permanência na área, como as ameaças constantes feitas por grileiros, ou como a construção de um muro, que dividiria a aldeia ao meio, iniciada pela Autoban, administradora privada da Rodovia dos Bandeirantes.

"Aí eu vim pra cá [para o Jaraguá] com o intuito de ajudar mesmo, quando eu cheguei aqui eu já falei pro Xeramõe 'vim tentar ajudar aí, no que for preciso, pra gente melhorar a situação, a gente sabe muito bem que vai levar tempo, aí, né, mas a gente não quer que aconteça alguma coisa com as mulheres, com as crianças aqui'".

No Jaraguá, William casou-se com Santa, filha de Karaí Poty, e construiu sua casa no núcleo de moradias dos parentes de seu sogro. Participou das atividades coletivas e ajudou na criação da associação indígena da aldeia, da qual é um de seus diretores. Hoje, além de membro da associação, acompanha o 
desenvolvimento dos projetos implementados por Furnas $^{27}$ e é responsável pela execução de projetos com parceiros como o Oim Porã ma Oré Rekó28.

Pedro Macena mudou-se mais tarde para o Jaraguá. Estava casado então com Marina, com quem teve três filhos. Além da falta que sentia das orientações espirituais de Karaí Poty, a sua saída da aldeia Tenondé Porã foi motivada por uma revelação em sonho.

“Aí no sonho... Um dia eu sonhei - nem conhecia aqui - onde ele estava. Aí no meu sonho eu vi esse lugar aqui. E no sonho eu cheguei aqui, e eu estava correndo aqui, com a minha família. Aí peguei e contei para a Marina [ex-esposa], 'o Xeramõe... to querendo ir lá onde ele está, queria ir lá onde ele está', e foi o certo. E vim pra cá".

Sua ligação com Karaí Poty é constituída por diversos fios: além da convivência que tiveram na Barragem, e do parentesco com a Xejaryi, o que mais sobressalta em seus depoimentos são os elementos relacionados à religiosidade Mbya, como os eventos ligados a uma agressão que sofreu por parte de um juruá, em Parelheiros (dos quais tratarei mais à frente), e a "doença espiritual", como traduz, da qual foi curado com a ajuda do Xeramõe, já no Jaraguá.

A atuação de Pedro Macena na aldeia também está ligada a desenvolvimento de projetos com não índios. Assim como seus irmãos Sérgio, Antônio e William, Pedro estudou por alguns anos em escolas regulares, tempo suficiente para que aprendesse a ler em português.

${ }^{27}$ Furnas - Centrais Elétricas, que desenvolve projetos junto aos Guarani como parte de acordo feito com os índios, a Funai e a Procuradoria da República, formalizado em um Termo de Ajuste de Conduta - TAC - pela passagem de linhas de transmissão nas áreas das aldeias de Parelheiros.

${ }^{28}$ Grupo Multidisciplinar de Extensão Universitária, ligado à Pró-Reitoria de Extensão da Universidade de São Paulo, USP, do qual participei. 
Mas o reconhecimento que tem como liderança se deve, principalmente, ao fato de ser considerado um dos oradores mais respeitados nas reuniões realizadas na opy. Além de constantes referências a elementos da religiosidade do grupo, em suas falas tem o cuidado trazer explicações adicionais e contextualizadoras. Por exemplo, quando tratam de algum assunto referente a alguma instituição dos juruá, ele se esforça para dar alguma noção do que ela faz ou representa. E nas discussões mais tensas, suas opiniões são consideradas moderadas e de bom senso.

Pedro casou-se recentemente com uma moça moradora da aldeia. Seus filhos (dois) moram com ele, e sua filha menor com a antiga esposa, que também já se casou e mora na mesma aldeia.

Sérgio e Antônio permanecem na aldeia Rio Silveira. Sérgio é considerado uma das principais lideranças da aldeia, elabora e desenvolve diversos projetos em conjunto com não índios e participa ativamente dos rituais cotidianos na casa de reza, sendo considerado um "rezador forte" pelos moradores da aldeia. Antônio é o diretor da escola, e acompanha as questões ligadas à educação indígena.

Quanto às irmãs Macena, não tive a oportunidade de acompanhar sua trajetória, tampouco de levantar elementos a seu respeito. Esquivos sutis nas conversas indicaram que este não seria um assunto fácil de abordar, pelo menos o suficiente para que sua posição estrutural e sua agência pudessem ser tratadas nesta dissertação. Permanece como mais uma tarefa a ser desenvolvida nos próximos anos. A participação na formação de opiniões e nas decisões, nas redes de pessoas que se formam em diversas direções, na religiosidade, enfim, em todas as áreas que uma pesquisa poderia formular como objeto, tem na posição feminina um lócus privilegiado de observação. No entanto, não foi (e talvez para mim não 
seja) possível, em campo, alocar-me nesse ponto de vista. Contribuirei no limite de minhas possibilidades. 


\section{2 - Formação do Tekoa Pyau}

Karai Poty, ao mudar-se com sua família para a aldeia do Jaraguá, construiu sua casa e as de seus familiares no espaço hoje designado Tekoa Ytu ("aldeia velha/antiga"). Ali, conviveu com Jandira e seus familiares por um pequeno espaço de tempo.

Mas uma característica pessoal, segundo Karai Poty, fez com que houvesse um rompimento logo após sua chegada: em todas as aldeias em que morou efetivamente, não apenas passando um tempo em visita - sempre se tornou a liderança principal, sendo escolhido para trabalhar como cacique, o que viria ocorrendo desde quando era recém casado.

No Jaraguá, entretanto, foi diferente. Jandira, a cacique desde a morte do marido, não abriu mão da posição. Mesmo assim, alguns de seus filhos homens entraram em disputa para ocupar seu lugar, enfrentando politicamente a mãe e o tio $(M F B S)^{29}$. Dessa forma, para evitar que surgissem conflitos mais graves e, ao mesmo tempo, para não abrir mão da tradição de ser sempre o cacique, Karaí Poty mudou-se para o outro lado da Rua Comendador José de Matos - área que era ocupada/utilizada pela família de Joaquim e Jandira desde sua chegada, na década de sessenta - e ali estabeleceu o Tekoa Pyau ("aldeia nova").

Ari, filho mais velho de Joaquim e enteado de Jandira, assume mais diretamente que possuía a pretensão de ser o cacique. Mas não mobilizou apoio suficiente. Mudou-se com a família para uma outra área do Pico do Jaraguá chamada de Sol Nascente, declarando-se cacique dela, no entanto, teve que sair de

\footnotetext{
${ }^{29}$ Filho do irmão do pai da mãe, ou primo da mãe, que classificatoriamente é considerado tio.
} Discuto alguns elementos do parentesco ao final deste capítulo. 
lá por causa da ocupação pelo MTST (supra:44), passando a residir no Tekoa Pyau. Desde então, a T.I. do Jaraguá passou a abrigar dois caciques e duas aldeias as quais, apesar da intensa relação cotidiana, tomam decisões e seguem caminhos diferentes.

Com o tempo, novos parentes e agregados se somaram à área do Tekoa Pyau. Uns, pelo parentesco, outros, pela liderança espiritual de Karai Poty. Há os que se mudaram apenas para realizar algum tratamento com o Xeramõe, e por lá ficaram; e há os que se mudaram para auxiliar na proteção dos moradores (por conta das ameaças de grileiros). Diversos são os motivos que os levaram ao Jaraguá, e todos eles se relacionam com o que se convencionou chamar na literatura etnológica de "mobilidade guarani", relativa aos processos de manutenção das relações de parentesco e aliança e à religiosidade do grupo. 


\section{3 - Características do Tekoa Pyau}

O tamanho da área ocupada pelo Tekoa Pyau é de cerca de 2,5 hectares. Ela era contínua à área do Tekoa Ytu, à oeste, a qual possui 1,2 hectare, mas nos anos 1980 foi construída a rua Comendador José de Matos, ligando a estrada Turística do Jaraguá à região sul do bairro, dividindo assim as áreas. O Tekoa Ytu conta ainda com um outro trecho, de cerca de 0,5 hectare, do qual é saparado pela referida estrada.

As aldeias contam hoje com equipamentos do Estado, como posto de saúde da FUNASA, uma escola estadual e um centro cultural municipal. Com o apoio de entidades beneficientes, foi construída no Tekoa Pyau uma cozinha preparada para fazer comida em grandes quantidades. A parceria garante uma cota mensal para aquisição de alimentos por meio do compromisso, por parte dos moradores da aldeia, de se fazerem atividades coletivas que envolvam os jovens. Assim, a principal das atividades desenvolvidas com eles é o controle da poluição ambiental produzida, em sua maioria, por recipientes de alimentos, como garrafas e sacos plásticos e caixas de papelão. Tais atividades ocorrem cerca de três vezes por semana e, de fato, reúne grande quantidade de participantes.

A área da Tekoa Pyau conta ainda com um campo de futebol, onde ocorrem jogos quase diariamente. Às vezes promovem-se campeonatos entre equipes, e os perdedores devem pagar aos vencedores com refrigerantes, que de qualquer forma são abertos na hora e tomados por todos.

Há entre dez e quinze banheiros coletivos espalhados pela aldeia (uns vão sendo construídos e outros derrubados). Mas, como não há ligação subterrânea com 
a tubulação de esgoto que passa por baixo da rua Comendador José de Matos, os detritos são despejados em fossas sépticas. Essas fossas, no entanto, já estão saturadas, e várias delas produzem vazamentos. Está em andamento, atualmente, uma obra que fará a ligação dos banheiros com o esgoto, implementada pela Sabesp em parceria com a Funasa. Mas algumas questões ainda estão por ser resolvidas, como a reivindicação por uma parte de moradores da aldeia de que seja construído um banheiro para cada residência.

Esse é um problema de se pensar em "coletivos" e "coletividades" onde não necessariamente existem. Pois, se é possível reunir uma grande quantidade de jovens para retirar o lixo do chão de toda a aldeia, ao mesmo tempo, é mais problemática a limpeza de banheiros que são utilizados por pessoas que não são da mesma família, muitas vezes nem possuem qualquer relação de parentesco.

Como em qualquer situação, ao se pensar em identidade há que se pensar sua constituição referenciada a alguma alteridade (e vice-versa). Assim, os comentários sobre o lixo espalhado pela aldeia talvez dêem uma dica para a interpretação desses fatos. Antes de se iniciarem os trabalhos coletivos de limpeza, reúnem-se os jovens na opy, onde passam alguns minutos ouvindo os discursos dos mais velhos, geralmente daqueles que estão coordenando a tarefa (os xondaro ruvixa $^{30}$ ). Nesses discursos, falam da importância de se cumprirem o compromisso que garante parte dos alimentos de que necessitam, da necessidade de se tomar cuidado com o lixo, pelas doenças que pode causar e da vergonha que podem sentir quando recebem um visitante, devendo, assim, cuidar para que não se joguem mais recipientes de alimentos comprados nos mercados dos juruá. Seguem-se assim os discursos (dois ou três), sempre frisando a relação daquele lixo com o juruá,

\footnotetext{
${ }^{30}$ Abordo esse tema das lideranças no capítulo III.
} 
lembrando que o que eles (Guarani daquela aldeia) produzem, como restos de alimentos e cascas de frutas etc., voltam para a terra, mas o lixo do juruá continua ali, e assim ficaria para sempre se não o recolhessem. Dessa forma, o trabalho realizado coletivamente tem como um de seus objetivos livrarem-se do que os jurua produzem, como resultado de um "modo de ser" (tekó) equivocado. Forma-se aí, nesse caso, a noção de uma alteridade jurua, de um lado, e de uma identidade Guarani, de outro.

Em um levantamento realizado no ano de 2007, constatei a existência de cerca de sessenta e cinco casas, apenas na aldeia Tekoa Pyau. E um total de trezentos moradores. As casas são distribuídas pela aldeia de maneira que formam agrupamentos aos quais chamam "núcleos". Não há uma tradução em guarani para essa palavra, mas ela é constantemente usada pelas lideranças para se referirem a esses conjuntos, mesmos nas reuniões que não contam com a presença de não índios.

O caso dessas aldeias no Jaraguá é específico em relação a outras aldeias considerando-se algumas questões. Primeiro, não é uma aldeia formada por um único grande núcleo de parentes. Há muitas famílias que moram ali não pela relação de consangüinidade com outros moradores, mas, entre outros motivos, pela presença do Xeramõe (xamã) Karai Poty.

Em segundo lugar, o espaço ocupado é diminuto, fazendo com que os grupamentos familiares se avizinhem entre si com poucos metros de distância. A aldeia próxima, Tekoa Ytu, é considerada a menor Terra Indígena do Brasil. Naquele caso, no entanto, a quase totalidade dos moradores é formada por descendentes de Joaquim e Jandira, possuindo laços de parentesco entre si. A situação no Tekoa 
Pyau gera uma série de desconfortos, os quais não se transformam em confrontos por causa da atuação de Karai Poty e de outras lideranças.

Na área da aldeia Tekoa Ytu está a Escola Estadual Djekupé Amba Arandy (criada por decreto estadual em 2001), que atende a alunos da aldeia da primeira à quarta série. O Centro de Educação e Cultura Indígena, $\mathrm{CECl}$, construído na Tekoa Pyau em 2003, atende a crianças até seis anos. Ali, há atividades de préalfabetização e palestras realizadas por membros da própria aldeia, tendo como tema algo de sua cultura, o qual considerem relevante e possível de ser transmitido naquele espaço. Segundo a coordenadora pedagógica da instituição, o espaço de aprendizagem das crianças indígenas extrapola os espaços do $\mathrm{CECI}$, por isso, está previsto no regimento da escola que qualquer espaço da aldeia pode ser utilizado pelos monitores indígenas para as atividades com as crianças. Os Guarani, no entanto, pelo que pude observar em campo, consideram que todas as atividades que desenvolvem com os jovens e as crianças fora do espaço do $\mathrm{CECI}$ não dizem respeito àquela instituição, mas a suas escolhas e necessidades.

Como compensação pela passagem de linhas de transmissão de energia nas aldeias de Parelheiros, o Termo de Ajuste de Conduta (TAC) assinado por Furnas previa, entre outras coisas, a recuperação ambiental das terras indígenas guarani em São Paulo. Na aldeia Tekoa Pyau já é possível perceber algumas mudanças positivas. No entanto, ao final do ano de 2005 eucaliptos caíram sobre as casas, ou tiveram grandes galhos quebrados por causa de uma forte chuva. Essas árvores já estavam doentes e a prefeitura, que já havia sido informada da situação, alegou que não poderia fazer as podas sem autorização dos órgãos de proteção ambiental eucaliptos não são árvores nativas, portanto, o trabalho poderia ter sido feito. Não o foi, e os Guarani tiveram que agir para resguardar a segurança de seus familiares. 
Assim, ao serem retirados os eucaliptos quebrados e apodrecidos, a área ficou descampada e exposta ao sol, vento e chuva. Isso dificultou o trabalho de reflorestamento, para o qual os Guarani se empenharam bastante. Aos poucos a área vem sendo recuperada, graças principalmente aos agrupamentos de bananeiras, mais resistentes, que vêm permitindo a conservação do solo. Os moradores da aldeia têm grandes expectativas em relação a esse trabalho, pois nas conversas contam seus planos em relação aos frutos das árvores que esperam crescer na área. E há quem fale da música que espera voltar a ouvir novamente: o canto dos pássaros.

Os Guarani têm acesso a todo o comércio da região. Feiras livres, supermercados, padarias, casas de material de construção entre outros. E há os jurua que vêm à aldeia para vender seus produtos, como pães, gás de cozinha, frutas, hortaliças e sorvetes. Alguns desses já conhecem alguns cumprimentos em guarani, como javy ju ("bom dia"31) e porã? ("tudo bem?"), e conhecem vários dos moradores pelo nome, fazendo controle de pagamento a crédito, no "caderninho".

Quando precisam ir à cidade tomam um ônibus que passa pela Estrada Turística do Jaraguá. Em geral, tudo de que necessitam buscam no próprio bairro, a não ser fumo de corda, o qual é comprado preferencialmente no Mercado Municipal na Lapa (Zona Oeste de São Paulo), ou no bairro do Brás (Zona Leste), onde há mais ofertas do produto e onde é mais barato.

Atualmente está em construção uma "tenda", no centro da aldeia, próximo à cozinha coletiva e à opy. Ela é feita com estrutura de metal e coberta de lona, e o piso está sendo cimentado. Quem a está fazendo são evangélicos da Assembléia de

31 A tradução literal é "nos levantamos de novo", onde ju é uma variante átona de jevy (“outro", "de novo", "de volta", conf. Dooley, 1998). 
Deus, que ali realizam cultos semanalmente (geralmente aos domingos de manhã). Há na aldeia quem questione aquela presença, primeiro, pelo barulho que produz com as cantorias e, segundo, porque estão ali para tentar convertê-los. Mas Karai Poty, no entanto, tem uma posição muito clara a esse respeito e a sustenta quando ouve comentários contrários aos evangélicos. Quando questionado se ele não se incomoda com o proselitismo, com as tentativas de conversão, ele diz que não, pois se estabeleceu com aquele grupo especificamente uma relação de respeito. Diferentemente de outros, os pastores que ali freqüentam não fazem qualquer referência às práticas cotidianas ou à religiosidade dos índios. É como se estivessem ali apenas para falar com eles mesmos. Além disso, há um pastor que, vindo do Paraguai, é falante do guarani daquela região. Isso não significa, no entanto, que as mensagens bíblicas se tornam compreensíveis, não porque os significados sejam ininteligíveis, mas os significantes: os moradores da aldeia não entendem quase nada do guarani do pastor. Às vezes, há quem fique no entorno, assiste ao culto por alguns minutos e sai.

Karai Poty diz que, se aparecem pessoas na aldeia para falar de deus, e não estão ali para agredi-los ou julga-los, então deve ter sido o próprio deus quem os mandou. Muitas das ações de Nhanderu se dão através das pessoas, sem que estas o saibam, e mesmo que o entendimento que tenham da religiosidade seja equivocada, como no caso dos evangélicos. Estes, diz o cacique, mesmo estando bem intencionados, não têm possibilidade de acesso ao conhecimento verdadeiro de Nhanderu, e o compreendem apenas parcialmente: esse seria o motivo pelo qual os cristãos acreditam que só existe deus (Nhanderu Ete, que criou o mundo) e Tupã, que dizem ser filho daquele, mas que na verdade é seu neto - Tupã é filho de Kuaray, e este é que é filho de Nhanderu Ete. Mas esse equivoco serve bem aos 
Guarani, afinal, evitam assim o confronto com religiosos mais radicais. Concordando com os pastores que existe um deus que criou o mundo, e que ele tem um filho, que se chama Tupã, para quem rezam (ou oram), os Guarani elaboram um meio de concordar totalmente com as palavras dos pregadores sem que se exponham ao conflito. 


\section{4 - Elementos do cotidiano}

A manhã começa aos poucos. Por volta das seis horas já se observam pessoas saindo de casa para as tarefas cotidianas. Mas a maioria não se entrega logo ao frio da manhã e prefere esperar até que sol aqueça o dia um pouco mais.

Por causa da mata do Pico do Jaraguá a madrugada é geralmente fria. É uma região onde ainda se vê a neblina que antigamente cobria toda a cidade pela manhã. Os que levantam cedo recolhem as madeiras que servirão de combustível para as fogueiras, espantando o frio e esquentando a água para tomar kaa (chimarrão de erva-mate). A madeira para a fogueira não é difícil obter. Sempre há algum caminhão despejando restos de andaimes, maderites, pisos de madeira, bancos de igreja, caixotes etc.

Logo, parentes se aproximam do fogo, e a cuia do chimarrão circula entre os presentes. Pouca ou nenhuma conversa. Às vezes alguém inicia a narração de um sonho que teve naquela noite. Ninguém comenta, deixando para refletir ao longo do dia (ou dos dias seguintes). Quando há farinha de trigo, preparam-se xipá (massa frita feita com farinha de trigo, sal e água), que pode ser obra coletiva de algumas residências ou preparado por apenas uma delas.

Por volta das dez horas, algum dos monitores do $\mathrm{CECl}$ sai pela aldeia chamando as crianças com um apito. É a hora do lanche da manhã, preparado pela cozinha da própria escola. A maior parte das crianças permanece por ali para as atividades do dia.

O período da manhã até por volta das duas da tarde é o preferido para as atividades domésticas. Lavar a roupa ou a louça nos tanques dos banheiros 
coletivos, fazer reparos nas casas, ir ao supermercado ou à feira livre, capinar o entorno das residências.

Depois desse horário, o sol já está forte demais para sair de casa. Então, ou procuram alguma sombra (pois as telhas de zinco tornam as casas desconfortavelmente quentes) ou ficam em casa assistindo televisão ou descansando.

O artesanato não é uma atividade cotidiana da maioria. Nem todos acham um bom lugar para colocá-lo à venda, nem têm a matéria prima necessária para produzi-lo. Quase sempre os artesãos dependem de possuir recursos antes de vender o artsanato, pois precisam comprar a matéria prima, ou esperam até que algum parente volte de alguma viagem a outra aldeia (como as do Paraná e as do litoral de São Paulo) trazendo geralmente sementes. Além desses fatores, a produção do artesanato depende da vontade de fazê-lo naquele dia, não é um trabalho com o qual se tem compromisso inadiável.

Ainda sobre o artesanato, não percebi divisão sexual da produção na maioria dos produtos. Qualquer um pode fazer brinco, colar, pulseira, cocar, mbaracá mirim (maracá, chocalho), ou os pequenos arcos e flechas. Mas não vi mulheres fazendo esculturas em madeira os quais reproduzem animais como quati, onça, jacaré, tucano, macacos, tartaruga, cobras etc. Por outro lado, também não vi homens fazendo cestos e balaios com o trançado característico guarani. Perguntados se há coisas que homens e mulheres fazem com exclusividade, respondem que não. Ouvi de alguns homens que até saberiam fazer os cestos das mulheres, só não o fazem porque não têm vontade e aptidão. Quase todos os que faziam artesanato se referiram a esses três fatores nas conversas: disposição para aquele tipo de produção, preferência por determinado tipo de artesanato e a certeza de que 
conseguem imprimi-Ihe beleza. São esses três os fatores os que parecem direcionar a produção individual.

Ao final da tarde as pessoas começam a se preparar para ir à opy ("casa de reza") e, assim que anoitece, são poucos os que continuam circulando pela aldeia. ritual cotidiano na opy tem uma população flutuante. Já vi rezas iniciadas com não mais de quinze pessoas e outras, sem motivo aparente, com quase cinquenta. Aqui parece ser também a vontade individual que determina se haverá reza com casa cheia ou não. Não há obrigação de comparecer absolutamente todos os dias. Geralmente o que se alega para não ter ido à reza é o cansaço por conta de alguma tarefa extraordinária realizada durante o dia. O ideal, disse Alizio, é que as próprias pessoas sentissem vontade, sentissem no coração que deveriam ir à opy todos os dias. É como antigamente faziam, e a reza durava a noite toda. Mas isso é uma coisa que, segundo ele, não vai acontecer mais - tudo mudou.

Dentre os que participam cotidianamente do ritual estão os Macena, os Gabriel e os parentes de Karai Poty (filhos e filhas com seus respectivos cônjuges e filhos). E são esses os que permanecem até o final do ritual, que dura entre uma hora e meia e duas horas e meia, dependendo da quantidade de rezadores no dia. Por último é quase sempre Karai Poty quem canta/reza.

Já houve ritual em que estavam apenas Karai Poty, Rosa e seus filhos Pedro, Vitor, Krexu, Tataxĩ e Taquá (filha "de criação") com os respectivos cônjuges e filhos. Nesse dia, não foi Karai Poty quem fez o encerramento do ritual, mas Pedro - mais velho que Vitor.

À noite os cachorros latem bastante. Qualquer movimentação noturna dispara o coral canino, que começa com um ou dois e termina com dez ou quinze latindo, mesmo que o causador do alarme não seja estranho, mas morador da aldeia. 
A cada latido é possível perceber uma movimentação no interior das casas através das frestas iluminadas. Não há tranqüilidade noturna. A aldeia foi engolfada pela metrópole, que trouxe seus problemas de violência que afetam a todos na cidade. Se por um lado o fato das casas estarem muito próximas umas das outras facilita o socorro em caso de necessidade, por outro, este espaço absolutamente distante do ideal gera incômodo no cotidiano, agravado por um espaço urbano caótico no entorno.

Houve crescimento desordenado nos bairros da região, com surgimento de novas favelas, pequenas indústrias e aumento no tráfego de automóveis. Além do crescimento vegetativo da metrópole, a obra do Rodoanel a poucos quilômetros da aldeia, ligando as rodovias Anhanguera e Bandeirantes forneceu facilidade de acesso para escoar a produção das indústrias, cuja presença aumentou por causa dessa mesma facilidade.

As discussões na aldeia, desde meados de 2007, se concentram na aquisição de uma área em Mairiporã - cidade próxima a São Paulo -, pela Dersa, órgão estadual responsável pela construção do Rodoanel Mário Covas e pelas compensações socioambientais relativas ao impacto desse empreendimento. Lideranças das aldeias Tenondé Porã (Barragem) e Krukutu têm discutido a possibilidade de empregar parte dos recursos a qual cada uma teria direito na complementação do montante destinado ao Jaraguá, para que a nova área a ser adquirida tenha a maior extensão possível.

Segundo Karai Poty esta não será uma terra dele, tampouco os caciques estariam doando-Ihe o dinheiro, pois, diz ele, "é Nhanderu que está vendo, Nhanderu mandou pra mim. Então é que... é pra tudo [todos]". Se é Nhanderu quem está fazendo com que essa nova área possa ser adquirida, da mesma forma é 
Nhanderu quem está conduzindo a garantia da área atual do Jaraguá (onde está o Tekoá Pyaú), já em processo de demarcação. Portanto, se a dádiva vem generosamente, generosamente deve ser redistribuída.

O acordo entre as lideranças dessas aldeias implica em dois pontos: primeiro, que a nova área seja livre para a circulação de qualquer Guarani; segundo, que se evitaria ali, a qualquer custo, a residência de não índios para coibir a mestiçagem. $E$, informalmente, e com sentido de anedota, também seria um lugar para acolher "caciques aposentados", que já trabalharam muito e querem um lugar onde apenas "ficariam ali, plantando uma rocinha".

Quanto aos elementos de religiosidade no Tekoa Pyau, descrevo algumas observações e informações obtidas em campo, como a participação nos rituais cotidianos na opy e as questões ligadas às doenças.

Observando os rituais cotidianos, percebemos que, em geral, os mais assíduos são os parentes mais próximos do Xeramõi, ou seja, seus filhos e filhas, genros, noras, netos. Também são assíduas as pessoas que não se ligam à sua família por parentesco, mas por outros tipos de aliança, como para o trabalho (os que desenvolvem projetos), ou para a própria reprodução da religiosidade (os que executam tarefas importantes nos rituais). Os cabeças das demais parentelas (tanto o homem quanto a mulher), também estão entre os que sempre vão aos rituais cotidianos.

Não notei, no período em que estive em campo, se alguma das famílias deixava de participar dos rituais na opy do Tekoá Pyaú. Em todas as famílias há sempre alguém que vai à opy ao pôr do sol, mesmo que não seja regularmente, ou seja, todos os dias. A freqüência aumenta em proporção à proximidade com família do cacique. Mas há muitas pessoas, famílias inteiras, que mudaram-se para a aldeia 
justamente pela sua relação com o próprio Karai Poty, ou seja, por conta de sua liderança espiritual como xeramõe (traduzido neste caso como xamã), independentemente de relações de parentesco.

Mário Macena, o mais velho dos irmãos é identificado como um importante auxiliador nos trabalhos na opy. Sua atuação está mais ligada aos rituais de cura, com a preparação do tabaco e o sopro da fumaça sobre o doente, antes que o próprio Xeramõe conduza o processo. Também Ronaldo, um rapaz jovem, casado e com um filho pequeno, é citado como atuante nos rituais da opy. É ele, geralmente, quem inicia os cantos e a condução da dança dos xondaro e xondaria, até que o xamã principal (Karaí Poty) tome seu lugar.

A opy, onde são realizadas as cerimônias religiosas, é uma grande casa construída com formato retangular, cuja extensão maior está disposta no eixo lesteoeste. É maior do que as residências das aldeias, feita de trançados de madeira ou de bambu, com as paredes barreadas e teto de telhas de barro ${ }^{32}$. A opy do Tekoa Pyau possui as dimensões aproximadas de dez metros de comprimento por cinco de largura.

Há, internamente, algumas divisões não muito definidas, mas utilizadas para determinados fins com certa constância. O "fundo", onde ficam as mulheres com crianças pequenas, sentadas sobre cobertores ou qualquer coisa que as proteja do chão de terra batida - pois esfria bastante durante a noite - é voltado para o oeste, o pôr do sol. Geralmente é o local de preferência para o xeramõi deitar-se e concentrar-se enquanto os xondaro realizam os cantos e danças iniciais. À "frente" está o amba, local onde são depositados os instrumentos musicais usados nos

\footnotetext{
${ }^{32}$ Há opy em outras aldeias que são cobertas de palha, o que é da preferência do grupo. No
} entanto, a duração desse material é menor, precisando de reforma completa em cerca de quatro anos, o que dificulta seu uso pelas aldeias urbanas. 
rituais, ou o avati (milho) e o kaa (erva mate) nos Nhemongarai (rituais de nominação). Mas também já ouvi referências ao amba como sendo todo o local onde se desenvolve o ritual de canto e dança - aproximadamente da metade da opy até sua parede leste. Ainda na parte interna, a opy é circundada por bancos quase sempre feitos com chapas de madeira compensada. Próximo à parede oeste fica uma cruz de madeira, de cerca de um metro e meio de altura, ornamentado com penas e colares. Os significados dos diversos elementos da opy não são de fácil acesso aos jurua. Quando perguntados a respeito, às vezes respondem dizendo que nem eles sabem os significados de tudo na opy, e que só o xeramõi saberia.

O destino da opy do Tekoá Pyaú tem preocupado a Karaí Poty, uma vez que acredita ser iminente sua saída da área para a nova aldeia em Mairiporã. Nas reuniões onde discutem problemas cotidianos e tomam decisões, o cacique tem inserido alertas em suas falas: "Esse opy aqui vai ficar aqui pra vocês que ficam, agora tem poucos, se repensar então vai ficar que nem [...], vai virar tudo a cabeça não sei pra onde". Nesse caso, não parece ser a opy propriamente dita a preocupação do cacique, mas a falta de uma liderança espiritual no local. Afinal, o que se acredita é que a aldeia é próspera porque tem um xamã (um xeramõe) que é suficientemente forte para receber dádivas de Nhanderu.

Assumir a casa de rezas não é um ato de obediência ao xeramõe pois, diz ele, não se "passa a opy” para alguém. Assumi-la é um ato de vontade individual e ao mesmo tempo uma resposta a um chamado de Nhanderu:

“Eu não vou dizer 'é você quem vai tomar conta ou é você quem vai tomar conta', aí não vai dar certo, então... Porque trabalho de Nhanderu é assim, não vem a coisa que... 'é você quem vai ficar pajé, é você quem vai ficar isso', não, não é isso. Cada um, do seu jeito que vai pensar 'eu acho que eu vou tomar conta, Nhanderu vai me ajudar...", diz Karai Poty. 


\section{Segundo Vera Mirim (Wiliam Macena),}

... existe a possibilidade de você vir com um propósito mas é o próprio Nhanderu que dá o seu destino, né. Assim, você veio com o propósito de ser xondaro, liderar um xondaro, grupo de jovens assim no opy, você lidera esse grupo e... eu sei que já ocorreu esses casos assim, né.

\section{Sobre um desses casos, conta Vera Mirim que o doente}

“[...] era jovem, esse rapaz era jovem, e ele pegou uma doença muito forte assim, doença nossa mesmo, aí ele ficou mais ou menos quatro meses sem levantar da cama... e o Xeramõe sempre fala assim 'mesmo que... se vocês estiverem doentes vocês tem que rezar bastante, vocês tem que ajudar os pajés e os xeramõe também, não é o xeramõe só, fazendo oração, né, você tem que ajudar os xeramõe também, assistir as rezas'...”.

É inevitável, nessa passagem, trazer à mente o texto de Lévi-Strauss (1996:193-213) através do qual teoriza sobre a relação entre o feiticeiro, o doente e o grupo para que a magia tenha êxito. Evocação ainda mais reforçada com a continuidade da história:

“Então, assim, aconteceu assim com uma pessoa, né, ele sofreu bastante, aí o Xeramõe falou assim 'o seu espírito ele não quer mais ficar na terra não, eu tentei de tudo mas, agora se o espírito olhar pela gente ele pode até viver de novo e, pro espírito voltar ele pode ter uma força a mais e ele pode até curar as pessoas'. Ele ficou assim quatro meses, ele ficou assim, magrinho magrinho, fraco, bem fraquinho mesmo. Aí a gente olhava pra ele assim, a gente não... [...]Não ia agüentar, né. E hoje ele é um pajé, isso é próprio da força dele, a força dele e também o espírito, né, a gente pode se tornar um pajé depois de passar dificuldade, né".

A viagem realizada pelo espírito do doente foi narrada pelo xamã para o doente. Viagem que foi transformadora, pois daquela situação de quase morte, passou-se a um xeramõi respeitado em sua e em outras aldeias. Esse tipo de 
transformação causada pela saída do espírito do corpo da pessoa não é incomum entre os Mbya. Conta ainda Vera Mirim que

“A gente pode ser pajé depois de passar dificuldade... mas, é assim, mostrado tudo pra gente, né, como se fosse uma televisão, aí você fica lá, vendo, tem uma pessoa falando pra você, 'você vai fazer isso, você vai usar o petyngua, você vai curar a sua comunidade, vai curar criança, vai curar as xejaryi, na hora em que elas estiverem doentes', então eles falam assim 'você quer fazer isso?'. Então a gente escolhe. 'Eu quero fazer'. Então a sabedoria vem depois que a gente se fortaleceu, depois que o espírito se fortaleceu, então o espírito vai se fortalecendo e a gente vai tendo mais sabedoria. É assim que é pra nós".

As doenças podem ter diversas origens. Ao perguntar a Karai Poty se seria possível uma pessoa causar doença em outra pessoa, o xeramõe do Tekoá Pyaú respondeu que sim, mas não é exatamente a pessoa quem produz a doença na outra. A doença seria fruto da ação de Anhã (traduzido na aldeia como "diabo") e seus xondaro agindo através da vontade das pessoas.

“Aí que eu sempre falava pro pessoal, não é pra um só que eu falo, 'não pode xingar, sem saber nada, não pode brigar, porque já aí também está errado, não pode xingar, falar uma coisa que não presta, né'. Porque a gente falando isso, já está vendo que aqui tem muita coisa aqui em cima do mundo que a gente não vê".

Os humanos são constantemente vigiados por seres aos quais não podem enxergar. Esses seres podem realizar uma agressão atendendo ao desejo de um humano, não através de uma ordem ou pedido deste, mas pela expressão de um pensamento ou palavra tomados de ira.

"É isso que eu sempre falo assim que 'vocês estão fumando aqui na opy, não pode brigar, não pode botar cara feia pros outros, tem muita coisa que não presta que a gente não vê. $\mathrm{O}$ diabo está vendo o quê que nós estamos fazendo'. Você xingou aquele cara, você falou assim 'eu vou te matar, um dia eu vou te matar', então é o diabo já está vendo que vai tomar conta dele. Aí o diabo 
manda o filho dele, que é o soldado dele tomar conta daquele cara, aí ele fala assim 'vai ficar pra nós"”.

Diz Karai Poty que as pessoas na verdade não agem "como se diz sobre os macumbeiros" (ou seja, atavés de seus próprios poderes sobrenaturais), pois a ação mágica é colocada em movimento por meio de uma intenção de agressão, mesmo que a pessoa não se dê conta disso - o que não diminui sua responsabilidade no evento.

“[...] foi o demônio que fez. Então é aí que a gente não tem culpa, só que a gente falou, né, então é isso que a gente tem que... respeitar. Nós Guarani é assim".

Então, as acusações de doenças causadas por feitiçaria são equivocadas na opinião do Xeramõi, pois seriam mais uma maneira de Anhã aumentar os conflitos e produzir mais ações maléficas.

“[...] 'foi ele que me xingou muito, disse que ia me matar então agora estou ficando doente; fiquei muito mal, ele fez macumba, foi pra isso, pra ficar isso que ele fez'. Não é na mão da gente que vai fazer isso. É o diabo que está fazendo, mandando fazer. Porque o diabo também é que nem Nhanderu, ta vendo tudo o que nós estamos... está vendo tudo o que nós estamos falando, né, de agora".

Agir corretamente é evitar o conflito e o revide.

“Agora se... se o rapaz xingou você, você saiu bem limpinho, não respondeu nada, aí já... Nhanderu está vendo isso aí. Porque já [?1:45'22"] eu não vou brigar porque já... eu não vou xingar porque já... eu não vou responder porque já... eu quero sair bem. Então aí já... está na mão de Nhanderu". 
Conhecer o certo e o errado, o verdadeiro e o falso, o bem e o mal, segundo Karai Poty, não depende apenas do contato com os xeramõi, mas também do ensinamento das divindades, pois todas as pessoas podem ter acesso a elas:

"Porque se você acredita mesmo em Nhanderu, conta tudo, vê tudo, mostra tudo o quê que está acontecendo com as crianças... com a comunidade. E eu estou vendo aqui. [...] Qualquer um pode ver. Se acreditou no Nhanderu, vê. Não é só pra velho, não é só pra gente que vai conhecer o negócio. É isso que a gente fala, tem que cada um que dar forma pra Nhanderu. Mostra, pede pro Nhanderu o que quer assim. Porque isso que Nhanderu manda". 


\title{
Capítulo III
}

\section{OO, KUERYA KATU, TEKOA: NOÇÕES DE ESPACIALIDADE E}

\section{RELAÇÕES DE ALIANÇA E PARENTESCO NA ORGANIZAÇÃO SOCIAL}

\author{
da ALdeia Tekoa Pyau.
}

\section{Introdução}

Neste capítulo, apresento uma descrição e uma análise sobre a formação e a interrelação de diferentes tipos de grupos no Tekoa Pyau: os moradores de uma residência (oo), os núcleos de residências (kuerya katu), as famílias extensas (etarã) e a aldeia (tekoa). É a partir das relações estabelecidas pela pessoa, tomando esses lugares como ponto de vista, que estabelecem-se diferentes relações de identidades e alteridades.

Assim, inicio o capítulo apresentando cada um desses conceitos. Em seguida, descrevo alguns elementos da organização social e espacial no Tekoa Pyau, coletados em trabalho etnográfico, tendo como referência os conceitos apresentados. Por fim, analiso a relação estabelecida entre esses conceitos, que participam da constituição da noção de espacialidade e do lugar da pessoa na estrutura social do grupo.

Como nos outros capítulos, os dados etnográficos da pesquisa de campo são colocados em relação com o material resultante da pesquisa bibliográfica, tanto 
sobre os Mbya como sobre os Kaiowa, com os quais a comparação fornece dados importantes para a análise etnológica. 


\section{1 - Os conceitos}

O ordenamento sócio-espacial da aldeia não é algo óbvio, tampouco pode ser percebido nas primeiras observações. A disposição das casas é, à primeira vista, caótica. Constroem-se casas onde os espaços permitirem, ou seja, se não houver obstáculo natural. Não há um alinhamento preferencial para posicionar a casa, seja em relação a pontos cardeais, ao sol etc, como há no caso da opy, (conf. supra p.90).

Tal liberdade e aparência caótica, entretanto, são relativas. A preferência geral é pela proximidade com a(s) casa(s) dos parentes, a partir dos consangüíneos lineares. Depois, há que se tomar cuidado em não ocupar uma área que vizinhos não parentes tomam por quintal - coisa complicada em uma aldeia com tão pouco espaço e tão povoada como o Tekoa Pyau, com cerca de dois hectares e meio e trezentos moradores.

O uso do termo kuéry deve ser cuidadoso nas descrições, pois pode generalizar algo não generalizável. Em Dooley (1998), kuéry é traduzido como

"2. Indica um grupo de pessoas relacionadas com um indivíduo referido: João kuery João e as pessoas relacionadas a ele (o relacionamento pode ser vago e informal)".

Ao perguntar sobre a localização dos parentes de Alizio na aldeia, usei a expressão Alizio kuéry. O interlocutor respondeu:

“Não, não. Então é uma palavra que você... só se o núcleo dele só se chama Alizio, né, (risos), então a gente pode falar assim 'Alizio kuéry'. No caso, se a gente for falar no jurua, é o "núcleo dos Alizios", que tenha mais gente com nome de Alizio".

Logo, como veremos nos exemplos abaixo, o termo kuéry deve vir acompanhado de mais algum elemento especificador se não se pretender tal grau 
de generalização. O termo é bastante usado para designar "os não índios", jurua kuéry. No caso de auto designações, há que se atentar para o contexto da fala, pois nhande kuéry pode tanto significar "nós, os Guarani”, "nós, os Mbya”, como "nós, dessa aldeia" etc. Logo, como em tudo que diz respeito a um elemento que representa identidade, sua constituição se dá na relação com a alteridade, ou seja, para saber de que "nós" estão falando é preciso saber a que "não-nós" (outros) se referem. 


\section{a) Oo: Residências.}

Sobre os Kaiowá, Pereira (1999 e 2004) descreve o "fogo familiar" (che ypyky kuera, literalmente "meus descendentes diretos") como a menor unidade sociológica desse grupo indígena. O autor rejeita a designação de "família nuclear" (geralmente pai, mãe e filhos pequenos/solteiros), sendo melhor tratá-la como "fogo familiar", pois abriria para a possibilidade do conceito acompanhar a complexidade gerada pelo dinamismo da circulação de pessoas de uma família. Além disso, a expressão proposta, segundo o autor, remete à comensalidade mais íntima do grupo, onde se partilham substâncias, produzindo vínculos e pessoas. Isso não é específico dos Kaiowá, evidentemente, e é encontrado também entre os Mbya ${ }^{33}$. No entanto, o conceito que esses últimos utilizam aponta para as relações entre local e geral, permanência e mobilidade, tendo como horizonte uma outra abrangência. Pereira (1999:83-84) afirma que

"O fogo é a unidade mínima fundamental, ordena as relações sociais no nível microssociológico, tecendo as malhas do tecido social. Qualquer pessoa tem que estar ligada a um fogo para que sua existência social se torne viável, quando a pessoa rompe com um fogo por casamento ou dissensão, imediatamente se insere num novo fogo. $O$ mesmo acontece com o visitante, mesmo não Kaiowá, que deve estar ligado a uma dessas unidades".

As oo ("casas" ou "residências") Mbya referem-se às construções físicas que abrigam, geralmente, mas não apenas, famílias nucleares. As famílias nucleares são compostas por um casal com seus filhos e/ou filhas solteiros. As casas, em grande parte, têm essa configuração, mas ela não dá conta da diversidade encontrada nas aldeias. Assim, uma casa pode conter parentes lineares ou colaterais, de um ou de

${ }^{33}$ Conf. Seeger, DaMatta, Viveiros de Castro, 1987. 
ambos os cônjuges. $\mathrm{O}$ que pode significar que uma casa pode ter apenas um único residente ou até dez ou mais. Os fatores que podem levar a uma ou outra condição são incontáveis. No Tekoa Pyau há duas casas onde mora apenas uma pessoa idosa, pois seus filhos se casaram todos e não moram mais com eles. Há pelo menos uma casa onde mora apenas um rapaz jovem, pois separou-se da mulher, com a qual ainda não havia tido filhos. Há uma casa com oito moradores, pois aguardam que outra casa fique pronta. Há uma casa com onze pessoas, entre adultos e crianças, pois seus anfitriões estavam recebendo a visita de parentes vindos de outra aldeia - os quais já estavam ali há três meses. Assim, ao falar em residências e não em residentes pode parecer que estes não são considerados aqui. Sim, são, mas não nesse nível microssociológico, pois que não foi o foco deste trabalho. São importantes, aqui, no nível em que estabelecem relações que compõem unidades mais representativas, como as famílias extensas, os núcleos residenciais e os tekoa.

Assim, o que se apresenta como diferente do caso dos Kaiowá descrito por Pereira tem implicações macrossociológicas. As possibilidades de rompimento não se dão apenas no nível das casas (ou dos fogos), mas também dos "núcleos de residências", das "famílias extensas" e do próprio tekoa (dos quais trato a seguir) vide as grandes mudanças de aldeia ou migrações realizadas por esses diferentes elementos da estrutura social. A referência à casa, oo, remete então não apenas à complexidade das constituições microssociológicas, mas também das relações que se estabelecem em esferas mais abrangentes. 


\section{b) Kuerya katu: Núcleos de residências.}

O conjunto de casas próximas é chamado "núcleo residencial” pelos Mbya do Tekoa Pyau, para o qual não há uma palavra específica em guarani, podendo ser usado nesse caso o termo kuery. Assim, ao se referirem a determinado local da aldeia podem usar a expressão "núcleo de Fulano" ou "perto de Cicrano e dos parentes", em português. Em guarani podem usam-se, por exemplo, Karai kuerya ("lugar [onde ficam as] pessoas ligadas a Karai”) ou Karai kuerya katu ("na direção do - ou perto do - lugar onde ficam as pessoas relacionadas a Karai"). Ambas as expressões, dependendo do contexto, podem designar tanto uma família extensa moradora de um núcleo residencial quanto o próprio núcleo, englobando assim os não parentes. No caso em que se pretende fazer referência apenas aos parentes de uma pessoa em um núcleo, podem usar o termo -etarã ("parente"), mas as vezes em que ouvi o seu uso havia a necessidade de se reforçar que era sobre estes que

se falavam, e não sobre todo o conjunto dos moradores do núcleo. (p.e. Fulano retarã kuéry ró py, "nas casas dos parentes de fulano").

O núcleo de residências, assim, não coincide necessariamente com a totalidade da família extensa, pois pode abrigar casas com indivíduos ou famílias nucleares que não têm relação de parentesco com a família extensa em questão. Além disso, a família extensa não está confinada nos limites de uma aldeia, pois os vínculos entre parentes que vivem distantes fisicamente se mantêm por meio da mobilidade (na qual se inclui não apenas as mudanças e migrações, mas também as visitas).

Um núcleo de residências, no entanto, tem como lastro um conjunto de parentes, lineares ou colaterais, aos quais somam-se os afins com os quais se 
estabeleceram alianças matrimoniais e, eventualmente, agregados, que tanto podem ser parentes dos afins quanto pessoas sem qualquer relação de consaguinidade neste caso, os tipos de aliança estabelecidos são outros, como os que se baseiam em amizade, trabalho ou religiosidade. É por isso que moradores de certas residências de um núcleo residencial podem ser identificados com a família principal desse núcleo mesmo que não possuam laços de parentesco. Assim, mesmo que um núcleo residencial, ou mesmo uma aldeia, não encerrem a totalidade da família extensa é necessário falar de sua presença nesses espaços, pois que, ao lado de outros fatores, lhes dá a base de sua forma e composição. 


\section{c) -Etarã: Famílias Extensas}

Pereira (1999:84-93) descreve a família extensa Kaiowá, te’yi, como sendo composta pelos parentes próximos de um -hi'u, um "cabeça de parentela" ou líder que agrega membros ao grupo. Ou seja, são diversos fogos reunidos em torno de um centro político, a residência do cabeça de parentela - o que não é apreensível pela observação da disposição geográfica dos fogos, mas das relações políticas e da microssociologia cotidiana. É no interior do te'yi que surgem os che jehuvy (literalmente "aqueles que ajudam"), formado assim grupos semi-autônomos pela aproximação entre fogos. Essa autonomia, no entanto, não se estenderia ao campo político-religioso, pois as cerimônias ocorrem no âmbito do te'yi ou do tekohá, nem também aos casamentos, pois o sistema de parentesco kaiowá estende o incesto a um grande número de parentes.

Aqui também há diferenças em relação à organização social mbya. O que mais se aproxima da idéia de "núcleos de residências" dos Mbya do Tekoa Pyau são os che jehuvy kaiowá. No entanto, os núcleos, ou kuerya katu mbya não são formados pelas residências de familiares próximos, mas nascem das alianças que as famílias estabelecem entre si. Se as famílias extensas são importantes para a fundação de um núcleo de residências, não são exclusivas nelas. Dessa forma, a constituição dos núcleos não é auto-referenciada, ou seja, não diz respeito a elementos internos, mas baseia-se nas relações que estabelecem entre famílias extensas, as quais extrapolam os limites dos núcleos.

Entre os Mbya, a autonomia dos núcleos pode estender-se para os campos político e religioso, revelados pela identidade de grupo que ali se constroem. No entanto, isso ocorre exatamente em oposição a uma alteridade constituída fora do 
grupo, geralmente referenciada nas relações de afinidade. Isso permite que certos núcleos de residências com uma parentela central forte tenham sua própria liderança principal e sua própria opy. Ao mesmo tempo, faz com que busquem fora de seus limites os afins indicados (ou pelo menos não proibidos) para o matrimônio. Os núcleos residenciais, dessa forma, são atravessados por relações de consangüinidade e de afinidade, por alianças e conflitos, ou seja, por diferentes relações de identidades e de alteridades. Assim, podemos encontrar casamentos realizados entre moradores de uma mesma aldeia quando há mais de um núcleo de residências, cada qual liderado por uma parentela diferente, pois de outra forma surgem impedimentos causados pela coincidência entre núcleo, família extensa e aldeia.

É o que ocorre em alguns tekoa com pequena densidade populacional, diminuindo as chances de se encontrar ali um afim com quem se possa casar. Apesar de ser esse o ideal, ou seja, um núcleo, uma família principal em um tekoa, a situação de contingência territorial não o tem permitido. O que não põe fim à circulação e à mobilidade, pois não se sai da aldeia apenas para casar.

Uma família extensa espacialmente organizada em um núcleo residencial é composta por um casal principal que mantém junto a si seus filhos e filhas casados e seus cônjuges. Parentes lineares (F, M, SS etc.) ou colaterais (MZD, FFBS etc.) do casal principal podem compor a Família Extensa. Sob a liderança do casal principal, parentes dos afins de seus filhos também podem ser atraídos, participando com a parentela da família extensa da composição do núcleo de residências.

Para as referências aos "parentes em geral" podem usar o termo -etarã (xeretarã, no lugar de ego: "meus parentes"). Esse termo é aplicado nos casos em 
que se referem ao conjunto de consangüíneos e colaterais, independentemente de seus locais de moradia (outros núcleos residenciais, outras aldeias).

Para designarem os "parentes mais próximos" acrescentam o termo ae'i, podendo ser tanto uma referência à consangüinidade como à co-residência em um núcleo. Ae"i, segundo Dooley (1998) significa "chegados" ou os "mais chegados" (xeretarã ae'i para o lugar de ego). Ou seja, o termo pode ser usado para se referirem, por exemplo, a irmãos e irmãs, e também àqueles parentes (não necessariamente consangüíneos) que residem em seu núcleo na aldeia - pois a residência é fator importante na definição das relações que podem ser consideradas incestuosas. Por exemplo:

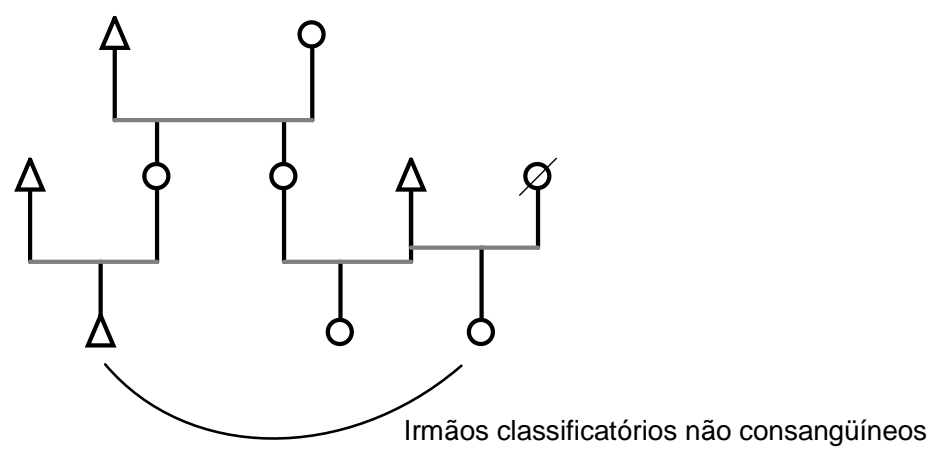

A família extensa também pode ter (e geralmente tem) uma composição que a faz extrapolar para além dos limites do tekoa. Primeiro, porque seus membros, por diversos motivos, podem estabelecer residência em aldeias ou em núcleos residenciais diversos. Essa separação, mesmo que implique em rompimento do convívio cotidiano, não desfaz a família extensa, pois ela persiste através dos vínculos que são constantemente atualizados por meio de visitas esporádicas, de mudanças efetivas, de encontros para a realização de rituais importantes - como os de cura, de nominação de pessoas e de celebração da renovação do ano. Em situações de conflito também é comum apelarem-se para o auxílio de parentelas em locais distantes, sejam esses conflitos internos à aldeia ou com não índios. 


\section{d) Tekoa: a aldeia.}

O termo tekoa pode ser traduzido como "aldeia". No entanto, para que isso não nos leve a crer que o espaço de uma aldeia encerre em si uma totalidade autosuficiente, apresento alguns dos elementos a que o termo tekoa se refere.

O tekoha, segundo Pereira (1999:94) é uma categoria designada por uma palavra que "é composta pela fusão de tekó - sistema de valores éticos e morais que orientam a conduta social, ou seja, tudo o que se refere a natureza, condição, temperamento e caráter do ser e proceder kaiowá - e ha, que como sufixo nominador, indica a ação que se realiza". Dooley (1998), no entanto, dá mais uma função à partícula $-a$, afirmando que ela "indica o lugar". Assim, como as referências a tekoha (tekoa para os Mbya) dizem respeito à espacialidade, acredito que a melhor solução seria considerar -a como lugar, portanto o lugar do teko. Por outro lado, é interessante pensar que a partícula refira-se às duas aplicações sugeridas, o que, aí sim nesse caso, sugere que pensemos o tekoa como "o lugar onde se pratica o teko"34.

Mais do que um lugar, o tekoa remete a elementos que dizem respeito às noções de espacialidade e de pessoa, assim como à cosmologia e à organização social. O cosmos e a estrutura social não são apenas múltiplos, reproduzindo uma miríade da mesma localidade ("o" tekoa), mas plurais, porque diversos em suas dimensões constituídas pela pluralidade de pontos de vista. Assim, na esfera celeste encontram-se as moradas de diversos deuses, cada um possuindo características, temperamentos, poderes e lugares próprios, mas relacionados entre si pelas

\footnotetext{
${ }^{34} \mathrm{~A}$ respeito do conceito teko faço algumas reflexões no capítulo IV e no capitulo V.
} 
posições hierárquicas ordenadas pelo parentesco ${ }^{35}$. Na esfera terrestre, as qualidades dos seres também são diversas, tornando diversos e plurais os pontos de vista tomados a partir do lugar em que se encontram. Misturam-se aqui nessa esfera a sociedade, a natureza e a sobrenatureza, não porque confusamente compreendidos pelos Mbya mas, ao contrário, porque eles os ordenam obsessivamente, tendo como referência os elementos constituintes do ideal de Nhandeva, do ideal de humanos. Assim, por exemplo, a narrativa que descreve o bando de kuaxi (anexo), liderado por um ser sobrenatural, mas cujo comportamento é referenciado naqueles mesmos elementos dos quais os Guarani nos falam constantemente, e que constantemente aparecem na literatura etnológica, designados por um conceito: o tekó.

${ }^{35}$ Seria importante abordar também as relações entre os lugares celestes e os deuses, e as relações destes com as pessoas Mbya. No entanto, esse é um conhecimento cujo acesso depende do pesquisador toma-lo como um projeto de vida, uma empresa de longo prazo. 


\section{2 - Notações sobre espacialidade e organização social no Tekoa Pyau}

É comum que o genro mude de sua aldeia natal (ou na qual esteja vivendo) para morar com os parentes de sua esposa, pelo menos até que nasçam seus filhos, podendo então partir para onde desejarem. Mas dependendo da força de atração do casal principal, seus filhos e filhas que já têm seus próprios filhos podem permanecer junto ao núcleo. Essa força de atração se baseia tanto em facilidade de acesso a recursos que forneçam subsistência e/ou prestígio, como em benefícios mágico/espirituais pela proximidade com a liderança xamânica que o casal principal muitas vezes representa. Não há um termo em guarani para este casal em conjunto, mas referências específicas a cada um, separadamente: xeramõi $i^{36}$ para designar o homem e xejaryi a mulher.

Este casal principal exerce uma centralidade no grupo da família extensa que se traduz em referencial para tomada de decisões nos mais diversos assuntos (mudança de aldeia, matrimônio, conflitos). O respeito é o balizador dessa centralidade, um tipo de autoridade que se baseia num consenso geral de que os aconselhamentos, as opiniões, as ações e os pedidos do casal central são dotados de bom senso e sabedoria ou de que sejam o resultado de sua eficiente comunicação com as divindades.

Concomitantemente, os chefes da família extensa (o homem e a mulher) são vistos como símbolos da identidade da família a qual o indivíduo pertence. Quando há questão que envolve a relação entre chefes de famílias extensas, a tendência é que o conjunto da parentela tome partido de seus cabeças de parentela, sentindo-se

${ }^{36}$ Dooley (1998) registra xeramoĩ, assinalando que a pronúncia é xeramõi, no que é seguido por outros autores. Por conveniência, prefiro manter no texto escrito a acentuação da pronúncia, ou seja, xeramõi (lembrando que o "x" tem o som de "tch"). 
tão afetado quanto eles pela contenda. O mesmo vale para agregados, como os parentes dos genros e noras, assim como para não-parentes cuja moradia encontrase na área de influência do chefe de família extensa.

Há, entre os núcleos, espaços públicos onde a parentela se reúne para conversar, tomar kaá (chá de erva-mate, chimarrão) e fazer artesanatos com miçangas, sementes e madeira. É comum manter bancos de madeira e tocos de árvore do lado de fora das casas para aproveitar alguma sombra, para fazer algum trabalho ao ar livre ou para receber visitas. Tais visitantes podem ser amigos, mas é mais comum que sejam pessoas da parentela dos donos da casa. Aos que não são parentes recebem com a fórmula "e aí, qual é a novidade?", já os parentes geralmente apenas chegam e saem sem que precisem explicar o motivo de estar ali.

O cuidado com os quintais é de responsabilidade de cada residência. Praticamente não há trabalho coletivo, mesmo no âmbito das famílias extensas. Plantio de mudas de plantas medicinais, árvores frutíferas ou ornamentais, assim como o cuidado posterior é atividade individual, a não ser quando os cabeças de parentela têm essa questão sob seu foco de atenção, quando então podem mobilizar o conjunto dos moradores do núcleo para a realização dessas atividades. O uso das plantas já crescidas e que dão frutos, entretanto, entra no circuito das relações internas ao núcleo residencial. O mesmo vale para as poucas criações animais (galinhas).

Diferentes dos "trabalhos coletivos", os trabalhos que se fazem juntos, como por exemplo a produção de artesanatos, são mais comuns. Sentados no chão, próximos uns dos outros, em um local do núcleo de residências, os participantes trocam entre si mais do que sementes e miçangas. Ali, compartilham informações e opiniões sobre os mais diversos assuntos, da sexualidade e da vida amorosa de 
membros da aldeia até questões relativas a decisões de lideranças, posturas de indivíduos em reuniões na opy, a participação (ou a falta dela) de membros de determinada família nos rituais cotidianos.

Houve alguns momentos em que optaram pela produção coletiva de víveres, quando eu imaginava que escolhessem a esfera da família extensa ou dos núcleos residenciais para tanto, como foi o caso de um projeto para implantação de galinheiros. A escolha de um único galinheiro para toda a aldeia foi uma decisão tomada em reunião de lideranças (chefes de família) com a representante não índia do projeto. Argumentavam sobre a importância da participação de todos, e usavam o termo "comunidade" para se referir ao conjunto da aldeia. Poucos meses depois, alguns núcleos já tinham seu próprio galinheiro, e em alguns casos, havia um galinheiro por casa.

Um dos projetos em andamento na aldeia ofereceu a possibilidade de criar pequenas hortas, onde as famílias ficariam responsáveis pela manutenção dos canteiros. Preferiram, entretanto, uma horta coletiva. Há, também, espaços onde estão sendo plantadas diversas espécies de bananeiras e outras árvores frutíferas, os quais são ditos coletivos (da "comunidade") quando perguntado a respeito. No entanto, em conversas cotidianas são tratados como "as bananeiras de fulano". O mesmo vale para a horta coletiva, da qual praticamente apenas uma pessoa cuida dela, e portanto é tida como a "horta de cicrano".

Acompanhando uma das reuniões que decidiriam pela coletivização ou não de determinada atividade, ouvi argumentos que davam razões bem práticas para a opção por uma única produção que rendesse fruto a todos. Com um espaço absolutamente insuficiente para as necessidades de uma população com quase trezentas pessoas, o que aconteceria com a produção por núcleo residencial seria 
que alguns poderiam dispor de uma área muito menor que os outros. Desejando obter da fonte de recursos que ali se apresentava os mesmos recursos para sua parentela que outras parentelas geralmente conseguem (umas com mais acesso a essas fontes que outras), os chefes de família presentes defenderam com firmeza a necessidade das produções coletivas. Discutiram então a necessidade do empenho de todos e da parcela de trabalho que cada família disporia para o empreendimento.

Contudo, a prática cotidiana do trabalho nem sempre reserva espaço para a coletividade. A obtenção de recursos é geralmente uma tarefa desenvolvida no âmbito da esfera privada, ficando para cada família nuclear tal responsabilidade. Nos casos onde uma família nuclear esteja em maiores dificuldades que as outras, ela é socorrida por sua parentela, mobilizando assim moradores de outras casas. E também há casos onde alguém da família extensa obtém algum recurso em quantidade suficiente para sua distribuição. Fora essas situações, o que é comum é que cada residência busque o alimento do dia.

No caso das tarefas coletivas ${ }^{37}$, elas vão sendo transferidas pouco a pouco para a esfera das atividades privadas, com alguém finalmente assumindo sozinho o trabalho e seus frutos, passando a ser o dono do recurso. Os projetos coletivos em andamento na aldeia também são constantemente questionados em relação à remuneração - há sempre alguém que exija pagamento para trabalhar neles. Tal exigência segue a lógica de que a produção da subsistência pertence à esfera privada, fora da qual é preciso compensação - não tem lógica não ganhar nada para "trabalhar para os outros".

${ }^{37}$ Sobre a experiência de desenvolvimento de projetos de trabalhos coletivos entre os Kaiowa e os Nhandeva de Mato Grosso do Sul, ver o trabalho de Almeida (2001), que apresenta situações muito próximas das que são vividas pelos Mbya. 
No cotidiano da aldeia as famílias extensas se relacionam por meio das famílias nucleares. Pessoas de distintas famílias freqüentam as casas uns dos outros seja pela proximidade (o que no Tekoá Pyaú, assim como no Ytu significa poucos metros), seja pela afinidade. Mas o mais comum é que os parentes consangüíneos se encontrem mais e passem mais tempo nas casas uns dos outros.

Materiais de todos os tipos também participam desses circuitos familiares. Desde ferramentas e equipamentos eletrônicos até fumo e alimentos. Em geral, a tendência é que as coisas circulem o mais próximo possível da parentela ligada aos chefes da família. Um genro que tenha trazido parentes para morar junto a si provavelmente encontra-se sob a liderança de seus sogros caso more no núcleo residencial destes, o que implica em dificuldade em fazer as coisas circularem na direção de seu grupo. Assim, uma postura mais generosa dos sogros é uma importante contribuição para a manutenção do maior número possível de agregados junto à sua parentela - postura essa que também é observada na relação entre o cacique ou xeramoĩ e o conjunto da aldeia.

Há núcleos de residências que permanecem mais afastados do conjunto da aldeia. Este afastamento se dá não apenas no espaço, mas também em relação às trocas materiais e atividades coletivas como as reuniões gerais. Contudo, quase sempre há algum membro da família participando do ritual cotidiano na casa de rezas, mesmo que parcialmente, ou seja, apenas nos primeiros momentos do ritual, quando, em circulo, sopram fumaça do petỹgua sobre o amba. Segundo Pedro Macena, o que fazem ou deixam de fazer durante o dia não interessa a ninguém, mas as pessoas reparam se ninguém da família vai à reza à noite ${ }^{38}$. Perguntado se

${ }^{38}$ Interessante notar aqui que é praticamente a mesma resposta dada por Verá Mirim quando perguntado a respeito da ocupação cotidiana dos adolescentes da aldeia. 
o problema era ter na aldeia uma família afastada da religião, Pedro respondeu que não, pois poderia até ser evangélico e contribuir de alguma forma para a aldeia. $O$ problema, diz ele, é se a pessoa não é evangélica e nunca vai para a reza, pois poderia significar que ela estava descontente com o Xeramõe.

Essa situação de relativamente pouca - ou pelo menos inconstante participação na opy pode ser um indicativo de que o ideal fosse que cada família tivesse seu próprio espaço para comunicar-se com as divindades. É possível que essa preferência tenha como objeto não apenas a opy, mas o próprio tekoa. Alguns fatos que observei em pesquisa de campo nas aldeias que visitei colocam-se a favor dessa possibilidade: a preferência de algumas famílias por realizarem o ritual cotidiano em suas próprias casas, a existência de duas, três ou mais opy em uma mesma aldeia e o estabelecimento de núcleos residenciais com grande distância entre eles (onde era possível de se fazê-lo, evidentemente). Também é um indicativo do quanto se entrelaçam os elementos da religiosidade com as relações políticas entre parentelas.

As famílias extensas no Tekoa Pyau não se ligam todas diretamente à família do cacique por meio do parentesco. Elas se interseccionam independentemente da relação que cada uma mantém com a família principal da aldeia. As alianças que se estabelecem entre as famílias como um todo tem como elo tanto as relações de parentesco, como as que se dão em torno da religiosidade, da amizade e da facilidade de acesso a recursos proporcionados por alguns "cabeças de parentela".

A distinção entre as famílias extensas é algo difícil de realizar. Por um lado, é possível afirmar que a aldeia é formada por apenas uma grande família, a de Karai Poty, definida pelos laços estabelecidos com seus parentes consangüíneos, com os parentes consangüíneos de sua esposa, e os parentes dos cônjuges de seus filhos. 
Por outro lado, a disposição espacial das moradias na aldeia e as atividades quotidianas revelam a complexidade das relações de parentesco Mbya.

Há três famílias que demonstram essa complexidade na área. Faço uma breve apresentação delas a partir de alguns de seus membros, relacionando-os à posição que nelas ocupam. Para distingui-las, chamarei as três pelo sobrenome não guarani dos cabeças de parentela: os Fernandes, parentes de José Fernandes (Karai Poty), cacique e xeramõe da aldeia; os Gabriel, parentes de Alizio Gabriel (Tupã Mirim), presidente da Associação indígena do Tekoa Pyau; e os Macena, Pedro (Karai Tataendy), Wiliam (Vera Mirim) e Mário (Karai Mirim), siblings que não formam um núcleo residencial próprio, mas cuja atuação se destaca tanto no desenvolvimento de projetos quanto nos elementos da religiosidade da aldeia.

Como se observa no croqui da aldeia (pg. 203) é possível distinguir o núcleo de residências relativo aos familiares mais próximos de Karai Poty (letra A), na parte Norte da área. São seus filhos e filhas, com os respectivos cônjuges, e parentes de sua esposa, totalizando dez residências naquele período de observação.

A autonomia para os moradores da área de um núcleo utilizarem os espaços entre as casas não é absoluta. Em geral as intervenções são feitas após comunicação ao chefe da parentela. Assim, por exemplo, Vera Mirim (Wiliam Macena) que pretendia plantar algumas ervas medicinais junto a sua casa, da mesma forma como o cacique tem junto à dele, foi aconselhado por este a fazê-lo em outra área, próximo à caixa d'água que serve a aldeia. Karai Poty foi consultado 
não apenas por respeito a sua autoridade de cacique, mas também por sua experiência de homem mais velho e chefe de sua família.

Dentre os moradores do núcleo residencial de Karai Poty, seu genro Vera Mirim é o mais envolvido com atividades que impactam sobre o tekoa: discute e executa diversos projetos em parceria com não índios, discute questões ligadas à escola (os objetivos, a didática, a estrutura física etc), coordena projetos de valorização cultural, participa das reuniões coletivas sobre questões internas - como decisões sobre mudanças na organização física da aldeia, problemas com os mais jovens, propostas de novos projetos. Mas antes de tudo, sua função mais importante é ser o principal apoiador/executador dos planos e desejos de Karai Poty.

A disposição de um genro não é apenas uma entrega voluntária de si, mas resultado também do compromisso que assume ao tomar uma esposa, a qual pode controlar parte dos recursos aos quais tem acesso. Doações de roupas que chegam à aldeia podem ter como destino uma determinada casa. Lá chegando, a mulher, após separar uma quantidade para seus próprios filhos, vai às casas das pessoas a quem pretende fazer chegar o recurso e, ou o leva diretamente para elas ou as chama para o pegarem em sua casa.

As mulheres também fazem circular os alimentos que chegam de doações. A regra geral (decidida em reunião das famílias) é que todo alimento doado seja levado para a cozinha coletiva e, depois de se verificar se alguém na aldeia precisa daqueles alimentos, integram-nos ao alimento estocado na cozinha. Tal verificação, no entanto, não tem uma regra específica. Diz-se que o ideal é fazer uma reunião na opy e convidar a todos. Mas às vezes a quantidade de alimento doado é considerada pequena, pelo menos o suficiente para ter que mobilizar toda a aldeia para uma reunião, então, quem recebe o alimento se encarrega de distribuí-lo. 
Há lotes de doações que são distribuídos no pátio, do lado de fora da casa de rezas, ou da escola. Neste caso, Krexu ou Tataxĩ, filhas do casal principal da aldeia, chama outras mulheres de sua parentela para ajudar a avisar do recurso e a distribui-lo. É o que parece ocorrer na maioria das vezes.

Krexu é uma das xondaria ${ }^{39}$ mais ativas, e considerada com canto forte ${ }^{40}$. Sempre que possível, Karai Poty a leva (junto com sua irmã Tatatĩ) com ele nas viagens para outras aldeias, quando é convidado para realizar, por exemplo, a cerimônia de batismo, o Nimongarai.

Krexu também participa ativamente das reuniões, sempre intervindo com opiniões e discordando frontalmente quando acha necessário. Tal atitude, no entanto, não é muito comum entre os Mbya, pois o que mais observei foi uma técnica de discordância onde o indivíduo discursa e depois ouve o discurso de seu oponente. Enquanto este último fala, aquele fica em silêncio, ou mesmo usa a expressão anheté, "é verdade", para depois voltar a falar e repetir sua opinião, ignorando a opinião do adversário. Outra forma que confunde (a mim pelo menos), é quando, após ouvir a réplica, o adversário volta a falar usando inicialmente quase as mesmas palavras do contendor, e terminar repetindo sua própria opinião. Isso acontece não apenas quando os opositores estão frente à frente, mas também quando se referem a questões de conflito. Nesse caso, ao abordar determinado assunto, saio às vezes sem saber se o indivíduo pretendia dizer uma coisa ou

39 Feminino de xondaro. Pessoas com função cerimonial de canto e dança nos rituais cotidianos na opy ou nos rituais anuais, como os de nominação (Nimongarai). Também designa os jovens que desenvolvem trabalhos sob a coordenação de um xondaroruivixá ("chefe dos xondaro"), ligadas a tarefas cotidianas ou à guarda da aldeia. Às vezes a palavra é traduzida na literatura antropológica como "corruptela de soldado". Sobre as posições, funções e significados das lideranças, trato no capítulo III.

${ }^{40}$ Ou seja, com marcação de ritmo e tom corretos ou apreciados nos cânticos religiosos. Sobre essa questão ver Montardo, 2002. 
exatamente o oposto desta coisa, sendo então necessário abordá-lo novamente em outros momentos.

Também Pedro Fernandes e Vitor Fernandes, filhos de Karai Poty, atuam com regularidade nos rituais desenvolvidos na opy. Pedro, o mais velho, diz preferir as atividades ligadas à religiosidade. Vitor, além de ser uma liderança nos rituais cotidianos na opy, também desenvolve projetos na aldeia, elaborados com parceiros não índios.

A parentela de Alízio Gabriel Tupã Mirim, que é casado com Tataxĩ, enteada de Karai Poty, encontra-se na porção Sudeste da área (sob a letra B no croqui), com doze residências. É um espaço de maior circulação de pessoas (a área da parentela de Karaí Poty é mais reservada), por causa de caminhos e áreas públicas no entorno. Neste núcleo encontram-se as residências dos filhos de Tupã Mirim, de seu irmão Maurício Gabriel (marido de Sandra, filha de Karai Poty) e de outros parentes seus.

Tupã Mirim é o presidente da Associação República Guarani Ambá Verá. Está sempre em contato com diversas entidades filantrópicas, ONGs e representantes de instituições oficiais (dos níveis municipal, estadual e federal). Seu irmão, Maurício, era até há pouco tempo o coordenador do $\mathrm{CECl}$, a escola municipal da aldeia.

Tataxĩ é considerada uma rezadora muito forte, o que faz com que seja levada por Karaí Poty em viagens que faz para outras aldeias, onde geralmente é convidado para dirigir a reza. Ela transita entre os núcleos de seu pai e de seu marido, ficando muito mais tempo neste último, principalmente por ter filhos e filhas casados no entorno, acompanhado-os no cotidiano. 
Nenhum dos outros familiares ou agregados de Tupã Mirim participa das reuniões das lideranças, nem está envolvido com projetos e atividades com não indígenas na aldeia, à exceção de Maurício, seu irmão. Sua família extensa não tem o mesmo peso político que a de Karai Poty, mesmo sendo numericamente maior.

Os familiares de Tupã Mirim formam numericamente a maior família extensa da aldeia. Já compunham um mesmo núcleo de residências quando ainda moravam na aldeia Tenondé Porã (Barragem). Quase todos mudaram-se dessa aldeia acompanhando Tupã Mirim para o Jaraguá, e outros vieram de aldeias do Paraná.

A atuação de Tupã Mirim e de Tataxĩ junto ao núcleo é um dos elementos que contribuíram para o seu crescimento. São considerados muito generosos na distribuição de recursos, e agem de forma a evitar ou superar conflitos que por ventura surjam no interior do grupo.

Mas, apesar de participar cotidianamente dos rituais na opy, Tupã Mirim não é considerado um xeramõe com sentido de xamã, como Karai Poty, mas de chefe de família extensa. Apesar de Tataxĩ vir se destacando cada vez mais nos rituais, participando dos momentos em que se realizam as curas, ela ainda não é considerada uma kunhã karai, mulher xamã. É possível que esses elementos contribuam para que Tupã Mirim ainda não seja o cacique de sua própria aldeia. Mas, ao que parece, é nessa direção que o casal caminha.

A família Macena, numericamente a menor, poderia ser uma das parentelas mais fortes e influentes. Trata-se de um grupo de siblings com grande iniciativa, assumindo a responsabilidade pelo desenvolvimento de diversos trabalhos na 
aldeia, assim como no estabelecimento de contatos com pessoas e entidades não guarani. Não formam, contudo, uma família extensa marcadamente diferenciada na aldeia, não tem um chefe de parentela, e não formam um núcleo específico de moradias.

Pedro Macena, que atuou na formação da escola, tinha sua casa próxima ao CECl até haver ficado doente. Depois de passar um período morando na opy com mulher e filhos, uma nova casa foi erguida (n45) próxima à casa de rezas, atrás da cozinha coletiva.

Mário Macena (casa ํํ22) também mora próximo à opy. Até 2006 seu filho Kelvin (Karai Poty Tupã) morava com ele, na mesma residência, quando este então mudou-se para a aldeia de Boracéia, na T. I. Rio Silveira, onde moram Sérgio e Antônio, irmãos de Mário. Sua filha, casada com um membro da Família Gabriel, tem sua casa no núcleo residencial de Alzio (B).

Wiliam Macena, casado com Santa (Krexu), filha do cacique Karai Poty, tem sua casa junto ao núcleo do sogro (A). Jaxucá (casa nº48), sobrinha (FBSD, filha do primo) de Pedro, Mário e Wiliam mora com o marido Evandro e os filhos no caminho entre a cozinha coletiva e o campo de futebol, atrás da casa de Pedro. Pedro e Wiliam são os mais ativos na relação com os não índios, e Mário, mais velho, é mais participativo nos rituais de cura na opy.

Mário Macena participa ativamente dos rituais cotidianos na opy, junto com Miguel (pai de um genro de Alizio) e José Fernandes. À diferença destes dois últimos, ele não canta (reza), apenas trabalha com curas espirituais. Mas é bastante respeitado nessa função, sendo por vezes solicitado que atue em algum caso específico (o mais comum, entretanto, é que Karaí Poty receba tais solicitações). Os primeiros cachimbos preparados pelas mulheres são para ele e para Miguel, sendo 
que Karaí Poty recebe o seu apenas para fazer a cura de alguém que tenha solicitado ou nos momentos antes de cantar/rezar.

Se Mário Macena restringe sua participação na reza aos momentos de cura, sem atuar no "canto/dança" (mboraei/jeroky ${ }^{41}$ ), sua performance parece, contudo, suficiente para garantir o respeito dos moradores da aldeia pela sua função. Depois de soprar a fumaça do petỹgua sobre determinada parte do corpo do doente, esfrega a mão sobre tal parte, como quem espalha uma pomada aplicada sobre a pele - é como se a fumaça de petỹ $\left(\right.$ tabaco $^{42}$ ) adquirisse outro estado de matéria ao entrar em contato com o corpo enfermo. Soprar a fumaça sobre alguém é uma parte do ritual que pode ser realizada por mais de uma pessoa, não se restringindo aos rezadores mais prestigiados. No entanto, apenas algumas poucas pessoas, a cada soprada de fumaça, sugam a doença usando uma das mãos como uma espécie de cone. A cada vez que se suga a doença, é comum o oficiante ficar tonto e perder o equilíbrio, pois é bastante intenso o uso do tabaco. Mas também parecem fazê-lo para demonstrar o quanto o combate é difícil e valoroso o seu esforço. A postura corporal e a seqüência de movimentos é muito própria desse momento, as quais observei serem reproduzidas em outras aldeias, por outros xamãs. No Jaraguá é mais comum observar tal desempenho ser realizado por Karai Poty ou Mário Macena.

Ao seguir para a fase do ritual quando sugam a doença e perdem o equilíbrio, concomitantemente com uma ânsia de vômito, um membro do grupo, geralmente um

${ }^{41}$ Dallanhol, 2002, em pesquisa na aldeia mbya de Morro dos Cavalos, em SC, notou a distinção entre jeroky (canto e dança realizados no exterior da opy, com fins lúdicos) e jerojy (canto e dança realizados no interior da opy com fins religiosos). No Jaraguá, no entanto, houve apenas referências à diferenciação da prática do jeroky (dança) e do mboraei (canto/reza), ambos realizados concomitantemente no interior da opy.

${ }^{42}$ Preferencialmente adquirido na forma de "fumo de corda". 
homem maduro ${ }^{43}$, posiciona-se atrás do curador e dá o apoio necessário. $\mathrm{O}$ apoio sempre se dá da mesma forma: o oficiante, desequilibrado, quando não vê que há um apoiador atrás de si recebe um aviso através de um toque na cintura, então desaba para trás. O apoiador enlaça o oficiante por trás, cruzando suas mãos frente à barriga deste, segurando-o, enquanto o xeramõe se recupera, vomita, ou produz um som de ânsia de vômito. Presenciei algumas vezes em que o xamã principal de uma aldeia realizava uma cura considerada mais difícil, permanecendo mais tempo sugando a doença, enquanto um xondaro ruvixa se posicionava atrás dele, garantindo o apoio. Nesse momento, o xeramõe retira de sua boca o objeto causador da doença: uma folha, um pedaço de casca de árvore, uma pedra.

Há, entretanto, uma diferença entre Mário e Karai Poty, que diferentemente deste, não recebe o apoio de um xondaro ruvixa. Todas as vezes em que sente o enjôo e a perda de equilíbrio encaminha-se para a parede Leste da opy, onde fica o amba ("altar", "morada dos deuses") e, apoiando-se, produz os som de ânsia característicos.

Mário Macena afirma que é a liderança espiritual de Karai Poty que o faz permanecer na aldeia. Já teria sido ela a causa de sua mudança para lá, e só não se mudou para outro lugar - uma vez que diz achar insuportável a vida naquele espaço tão pequeno - porque irá "aonde o xeramõe for". O mesmo me foi dito por Wiliam e por Pedro Macena.

Pedro Macena esteve casado até o ano de 2007 com Marina, cujos pais encontram-se na aldeia Palmeirinha, na cidade de Mangueirinha, Paraná. Tem três filhos pequenos com ela, mais três jovens que moram na aldeia Tenondé Porã

${ }^{43}$ Ele pode ser chamado de xondaro ruvixa, um "líder dos xondaro". Sobre liderança, ver infra capítulo III. 
(Barragem) com sua ex-esposa. Desde o início de minha atividade junto ao grupo Oim Iporã ma, em 2006, notei a presença constante de Pedro Macena na discussão de projetos, sua eloqüência nos discursos e sua relativa facilidade para leitura de documentos em português.

Este último item é, de fato, um diferencial dos Macena, pois poucos outros homens na idade acima dos trinta e cinco anos (aproximadamente) têm essa facilidade. À exceção de Mário, o mais idoso dos irmãos, todos os siblings Macena dominam a escrita e a leitura, não apenas Pedro e William no Jaraguá, mas também Sérgio (que é vice-cacique e representante regional de saúde) e Antonio (que é diretor/coordenador da escola) ambos da aldeia Rio Silveira. Segundo Pedro, seus estudos foram realizados por conta da insistência de seus pais. Fizeram os primeiros anos do antigo ginasial, depois desistiram, tanto pela pressão do preconceito nas escolas não indígenas, como pelas constantes mudanças de aldeia, até a mudança para a aldeia da Barragem. Esse tempo de estudo, entretanto, foi suficiente para que aprendessem a ler e escrever em português. 


\section{Capítulo IV}

\section{LIDERANÇAS}

\section{Introdução}

Mesmo que possivelmente implique em limitar a análise, opto, neste capitulo, por tomar a expressão xeramõi (literalmente "meu avô") como um substantivo que designa um lugar entre as lideranças da aldeia. É a forma como já ouvi ser usada na aldeia, em diversas ocasiões, mesmo em conversas entre os próprios Guarani Mbya. Nesse caso poderiam ter usado a expressão nhaneramõi (forma inclusiva do pronome possessivo "nosso", caso não me considerassem participante da conversa) ou oreramõi (forma exclusiva, caso percebessem que eu entendia o que falavam).

Nhanderuvixa ("nosso líder", "nossa liderança") é um conceito bastante flexível à primeira vista. Pode ser uma referência a pessoas que lideram o desenvolvimento de projetos na aldeia, a pessoas que lideram um grupo de xondaro, a pessoas que desempenham certos papéis em rituais na opy, assim como aos lugares do cacique ou do xeramõe (xamã). No entanto, essa flexibilidade encontra alguns pontos de convergência que podem, assim, ser definidores do conceito: conhecimento e sabedoria; a relação que estabelecem com as divindades; e a capacidade de conduzir um grupo. Dessa forma, a liderança é baseada em uma autoridade que se assenta no respeito dos membros do grupo por reconhecerem no líder essas qualidades. 
Segundo Vera Mirim (Wiliam Macena),

"A liderança não pode agir sozinho também, ele tem que agir com a comunidade, ouvir as palavras da comunidade, ouvir as coisas que a comunidade necessita, né, e ser bom com toda a comunidade, né. Ele não pode ter... assim... ser nervoso demais, tem que ser calmo, saber conversar com os parentes dentro da aldeia e saber conversar com as pessoas fora da aldeia. Trazer recurso, né. Então a liderança é essas pessoas".

Dessa forma, a prática da liderança exige auto controle e retidão de caráter, "não pode mostrar cara feia, não pode mostrar... falar uma coisa que não presta, não pode falar uma coisa dos outros, tudo isso tem que levar bem limpo, aí que o Nhanderu dá força pra gente", afirma o Xeramõi (José Fernandes, Karai Poty).

Encontramos na literatura etnológica mbya diversas referências e descrições sobre as lideranças e seu papel nas aldeias. Trago neste capítulo algumas dessas referências que nos ajudarão a fazer um breve balanço do tema e, dessa forma, contribuirão para as reflexões propostas nesta dissertação sobre as relações que se estabelecem entre identidades e alteridades do ponto de vista das lideranças.

Dentre esses trabalhos, o de Vietta (1992) é o que traz um maior detalhamento dos conceitos de chefia/liderança Mbyá. Segundo a autora (idem:66), os problemas internos às aldeias são discutidos por um grupo de pessoas conhecidas como lideranças. Fazem parte da liderança de uma aldeia o cacique, o capitão, conselheiros (um ou dois) e policiais. São eleitos para estas funções (eminentemente masculinas). Não há tradução para o mbyá, segundo a autora, das designações dadas a essas funções, mas seus papéis referem-se à organização específica das aldeias guarani.

Os membros da liderança, segundo a autora, discutem tanto os conflitos internos como aqueles gerados pela relação com os não-índios (sendo que estes 
últimos os que geram maior demanda). É papel da liderança "manter presente, como ponto de referência o que eles identificam como o modo de viver dos antigos" (idem:ibdem).

Logo, conforme a autora, para ter o respeito e o prestígio necessário para ocupar a função, o integrante da liderança deve demonstrar preocupação pela manutenção da tradição, e comporta-se de acordo com ela. O discurso e o exemplo são os instrumentos para manter o grupo coeso em torno do sistema de valores Mbyá. Segundo Vietta, são duas as referências para a construção desse sistema: o discurso das lideranças a respeito do modo de ser dos antigos e os elementos considerados como pertencentes ao sistema de valores dos brancos. Os papéis das lideranças, mesmo distintos, confundem-se em diversos momentos da prática cotidiana, principalmente nas situações em que é necessário substituir momentaneamente um líder ausente. As referências que encontrei no Jaraguá a respeito das lideranças também faziam menção à relação destas com o "modo de ser" (tekó). No entanto, não eram referências que apontavam apenas para o passado, para "os antigos", mas principalmente para o futuro, o "vir a ser", pois das práticas de acordo com o tekó depende o destino das pessoas.

Assim, discuto inicialmente, neste capítulo, as considerações dos Mbya do Tekoa Pyau a respeito do conceito de liderança e sua possível origem. Em seguida apresento como as lideranças são formadas, ou seja, como surgem os elementos que as caracterizam, para então tratar com maior ênfase um desses elementos: o conhecimento. Por fim, apresento uma descrição de algumas posições de liderança, como se relacionam com os moradores da aldeia e com outras lideranças: xondaro, xondaro ruvixa, ruvixa e xeramõi. 


\section{1 - Como pode ter surgido o conceito liderança}

Liderança é um termo para o qual não há tradução única e direta. Ao perguntar sobre o assunto, Vera Mirim (Wiliam Macena) assim respondeu:

“Olha, liderança... eu não sei assim, muito bem explicar porque... agora não sei como que surgiu essa palavra, né, porque... pra gente, tinha o conselheiro, né. O conselheiro seria assim... porque há muito tempo, né, na aldeia, tinha os conselheiros e as conselheiras, né, que seriam os mais velhos, né, que davam conselhos, e se acontecia alguma coisa assim entre famílias, ou, entre parentes, então eles iam lá aconselhava, né, a gente tinha esses conselhos, né. Agora, é... assim, liderança acho que surgiu há pouco tempo, no meu ponto de vista, porque liderança ele pode, assim, é... fazer várias coisas, ele pode pegar várias frentes de trabalho, no meu entender, né. Assim... ele pode ser um membro da associação, ele pode ser representar a comunidade em outros... não tendo uma associação tem alguma pessoa que representa... cacique mesmo. Cacique é um representante e é uma pessoa que pode trazer informações, trazer projetos, então essas pessoas são as lideranças".

Os termos nativos que o designam são múltiplos, isso porque não designam uma posição, mas posições na organização social do grupo, ou seja, ele condensa uma pluralidade de conceitos. Há aproximações que foram sendo construídas na relação com os não índios, o que pode ser observado no próprio uso do termo liderança, em português, mesmo quando falam entre si, em guarani.

Mas qual o seu significado? Como veremos, o termo genérico "liderança", que designa aqueles que desempenham papéis de mando, comando e autoridade, é composto pelos mesmos elementos que compõem designações mais específicas. Interpreto tal fato como sendo uma forma que os Mbya utilizam para se apropriar de um conceito, dando-Ihe um lugar a partir das relações que estabelece com outros 
conceitos. O mesmo pode ter ocorrido com o termo "capitão" e possivelmente xondaro (considerado na literatura etnológica como corruptela de "soldado").

$\mathrm{Na}$ avaliação de Tupã Mirim (Alizio Gabriel), o próprio conceito de cacique Ihes é estranho. Mas não por isso é ininteligível, uma vez que tomou lugar em um quadro conceitual pré-existente.

"O cacique e os pajé eles... antigamente a gente tinha só os pajés. Pajé era nosso chefe, só que depois dali, o próprio juruá colocou que tem que ter cacique, que tem que ter esse nome".

E também:

“Então, eu da minha parte até hoje eu não gosto de falar assim 'cacique'. Porque muitas vezes a gente vai pra resolver alguma coisa pra comunidade, muitas vezes assim pra demarcação da área indígena, é que eles [os juruá] exigem mais é presença do pajé, presença do cacique, presença do presidente da associação, então, é por causa disso que nós temos cacique, que nós temos pajé, tem que ter outra organização que não faz parte da cultura indígena. Mas, tudo isso nós vamos ter porque as coisas estão mudando".

O termo "capitão" surgiu, provavelmente, por causa da secular relação entre militares e povos indígenas, o que ocorre ainda hoje uma vez que em muitos lugares eles figuram como a única representação do Estado brasileiro. E ganhou continuidade de uso com as entidades civis de indigenismo do Estado. Já o termo "liderança", pelo que pude notar nas entrevistas, teve seu uso apropriado pelos Mbya nas últimas três décadas. Esse é um tema que ainda deverá ser estudado e aprofundado, no entanto, como hipótese, considero que as relações com os movimentos sociais e políticos pré e pós redemocratização do país tenha contribuído para o termo viesse a ser utilizado, pois faz parte do jargão desses movimentos, complementado com a idéia de "comunidade" (também usado pelos Mbya). Essas 
idéias totalizadoras como "a liderança" ou "a comunidade" ainda são empregadas pelos representantes da igreja católica, através do Conselho Indigenista Missionário (CIMI). E ao serem empregados pelos Mbya ajudam-nos a manter plural o que às nossas vistas é apresentado como único - estratégia também adotada para as referências a elementos da religiosidade, como o termo Nhanderu (literalmente "nosso pai"), sob o qual reside o politeísmo Mbya. Consequentemente, apenas a etnografia, obsessiva, intensa e atenta pode revelar aquilo que nós, os jurua, os ajudamos a esconder. 


\title{
2 - Como se formam lideranças
}

\author{
Disse-me Vera Mirim:
}

"Porque assim, cada um de nós tem o nosso propósito, né, que o próprio Nhanderu coloca, "você, vai liderar seus parentes" então você já vem com esse propósito. Se Nhanderu falar assim pra mim "você vai ser xeramõe", então eu vou ser xeramõe; "você vai ser xondaro", então vou ser xondaro. Então, é... se você tem xondaro ele pode... é como se fosse assim lá no juruá. Tem o prefeito, tem o vereador que é abaixo do prefeito, e tem o subprefeito, né, ele coordena lá a cidade. É quase... assim também o..., tem o xondaro, ele pode ser depois de quatro, cinco anos, ele pode ser um uvixá. E se Nhanderú falar assim "você...", se ele veio com o propósito de ser xondaro, uvixá e xeramõe, aí depois de muito tempo ele se torna xeramõe".

Assim, o lugar da pessoa é determinado de antemão, já pelo nascimento segundo Vera Mirim. A diversidade de posições sociais diz respeito à sua organização hierárquica (daí as referências a vereador, sub-prefeito, prefeito). O que fica velado sob a referência genérica às divindades - Nhanderu - é que a hierarquia das posições sociais terrestres relaciona-se com a hierarquia das posições divinas/sobrenaturais celestes. E essa diversidade (tanto a celeste como a terrestre) incide sobre a divisão do trabalho.

\section{Conforme Vera Mirim:}

"[Nhanderu Papa] que é pai de Kuaray. Nhanderu Tupã, que é mais na parte de Tupã, ele que coordena a... E Nhanderu Nhamandu que coordena a parte do dia, né, que é quando Kuaray vem, Nhanderu Nhamandu. [...] é como a gente estava falando de liderança, né, então cada liderança tem seu próprio grupo de trabalho, né, é ele que coordena todos os trabalhos do dia. À noite já é 
Jaxy, é ele que coordena o trabalho da noite. É... Nhanderu Tupã ele pode... ele é o mais temido, né, então a própria comunidade, nós, a gente tememos muito Tupã ${ }^{44 "}$.

E é Tupã, segundo Vera Mirim, quem detém os conhecimentos sobre a produção de remédios e os transmite aos xeramõi ou às kunhã karai.

Segundo Ferreira (2001:53) o "representante" - categoria identificada pela autora em aldeias Mbya no Rio Grande do Sul - deve ser uma "pessoa que tenha 'nascido para isso', que seu 'espírito' tenha sido enviado por Deus para exercer tal função".

Quando perguntei ao Xeramõi se a alma já nasce com uma definição dada por Nhanderu sobre o que a pessoa fará na Terra, ele respondeu que a determinação de Nhanderu para a alma-palavra que vem à Terra é simplesmente que ela "tem que ser forte, pra não ficar errado por aî". Mas com o passar do tempo a pessoa, em geral, esquece esse conselho de Nhanderu, então "faz tudo o que quer, então... briga, mata, porque aí já... fica muito pecado", afinal,

“Nhanderu mandou pra Terra assim pra... viver, por mais que nós vamos ficando velhinho, tem que alcançar, quer ser... engatinhar; você quando fica velhinho vai ficar engatinhando, que nem as crianças, então, depois disso que tem que morrer. É isso que Nhanderu manda. Hoje em dia não, porque... vinte e cinco, trinta anos já morre em briga, matou o outro".

${ }^{44}$ Karai Poty conta uma história segundo a qual um grupo de pessoas trabalhavam na mata. Logo, uma tempestade começou a se formar, então os Mbya que ali estavam pararam de trabalhar e foram buscar abrigo, enquanto os jurua lá permaneceram, pois diziam não ter medo de "uma chuvinha". Então, um raio caiu sobre os trabalhadores, matando-os ou atirando-os longe. Com essa história, ilustra o argumento de que todos devem se recolher e rezar para Tupã quando estiver trovejando muito, evitando, inclusive, falar em voz alta. 
O conhecimento oferecido por Nhanderu é o bom modo de agir. Nesse caso, a referência ao tekó ("modo de ser guarani"), na resposta de Karai Poty, tem implicações sobre a própria duração da pessoa ${ }^{45}$.

As pessoas mais velhas são consideradas mais sábias, daí o respeito que merecem. Ainda que essa não seja uma relação necessária (pois o conhecimento pode ser transmitido pelas divindades a um jovem, que é então considerado um xeramõi - xamã - pelo grupo), é a condição reservada à maioria das pessoas. Assim, na esfera dos indivíduos, estabelece-se uma relação mútua entre tekó e temporalidade: viver de acordo com o tekó leva a se viver mais; quanto mais se vive, mais sábio e mais conhecedor do tekó se torna.

Insistindo ainda na questão sobre a influência dos nomes das pessoas no tipo de trabalho que fariam, o Xeramõi respondeu que tal influência não existe. A única determinação com que a pessoa nasce é "fazer o bem". No entanto, é necessário buscar constantemente coisas novas para fazer, experimentar, ir para outros lugares. Ou seja, a mobilidade é um instrumento importante para produção de conhecimento e, portanto, para a formação da pessoa mbya.

Temos aqui uma contradição entre os informantes Mbya. Para um, há influência direta, uma determinação das divindades sobre o lugar da pessoa. O outro disse que não há, e na resposta fez referências à temporalidade e à mobilidade. A questão dos nomes não foi objeto desta pesquisa dados os seus diversos limites, mas é um tema que deve ter um trabalho com dedicação exclusiva, porque complexo e interrelacionado com diversas esferas da vida social dos Mbya ${ }^{46}$.

${ }^{45}$ Sobre o tema da duração da pessoa, ver Pissolato, 2006.

${ }^{46} \mathrm{O}$ ponto de partida para tal pesquisa deve considerar o levantamento feito por Ladeira (1992), que lista termos e nomes relacionados com determinadas divindades. 
Não procurarei, assim, elucidar a referida contradição, mas chamo a atenção para o que há ali em comum: em meio às diferentes abordagens, nas quais surgiram temas como pessoa, temporalidade e mobilidade, um elemento era constante, o tekó, o "modo de ser" guarani, que nem sempre é "nominado" na fala, mas faz-se presente pelos elementos que o constituem. Mais à frente faço algumas considerações sobre o tekó, somando outras observações à que foi apresentada acima.

A expectativa de Karaí Poty é de que seus filhos (Pedro Fernandes e Vitor Fernandes) venham a se tornar caciques também. Entretanto, isso não é dito diretamente, seja porque o destino da pessoa depende da vontade das divindades, seja porque as escolhas individuais devem ser respeitadas - afinal, essas escolhas também são fruto da relação/comunicação entre o indivíduo e a divindade. Mas a expectativa é revelada em situações como, por exemplo, quando comentado que seu filho Pedrinho havia dito que não gostava muito de lidar com juruá, preferindo o trabalho na opy, Karaí Poty respondeu que "é porque cacique tem que ser isso. Ele já não pode esquecer [das divindades], tem que se levantar de manhã cedo, fazer trabalho [na opy], tem que fazer como juruá, né, tem que fazer oração".

$\mathrm{Na}$ avaliação do cacique, essa não tem sido a postura dos novos caciques, o que explicaria a fraqueza que identifica neles:

"Mas eu acho que hoje em dia os caciques novos assim, eu acho que já não pensa isso, por isso que fica fraco. E antigamente não, quer dizer, eu, Nivaldo, Jijocó, Altino... ○ Capitão Branco finado, eles que tem tudo esse... tem que fazer isso: não esquecer da opy, não esquecer de fazer a oração, não esquecer de dançar, dança toda tarde, toda noite. É assim".

"Não esquecer-se" (dos deuses) é o que fortalece. Karaí Poty conta que há quem diga que ele é importante porque os juruá fazem coisas para ele. Então ele 
explica que isso acontece porque "tem juruá kuéry que está repensando um pouco a vida. Porque é Nhanderu que está falando. [Juruá] que vem de outro lugar, assim, pra ver as coisas assim. E isso tudo está na mão de Nhanderu" . Ou seja, ele não se opõe à idéia de que muitos não índios trabalham a seu favor, mas o mérito seria de Nhanderu, divindade que envia aos que não se esquecem dele diversos bens, dentre estes os jurua. A mesma argumentação é usada para responder quando perguntado sobre o que acha quando dizem que ele é um grande pajé: "toda aldeia pensa que eu sou o mais forte, que eu sou grande, mas não é isso"; e também em relação às famílias que superpovoam um espaço tão pequeno como o do Jaraguá: as pessoas o seguiram para lá "pois é Nhanderu quem está puxando pra dar força".

A formação de novas lideranças é um cruzamento de diversas situações, como a predisposição da pessoa, o lugar que já ocupa tendo como ponto de referência as relações entre as famílias, características pessoais, aquisição de conhecimento e o reconhecimento de que este é válido e importante para o grupo. Mas também há a ação por parte das lideranças já instituídas, que pode ser orientada para a produção de novas lideranças. Assim, em relação ao Tekoa Pyau, diz Karai Poty,

“[...] nós estamos dando força também pra surgir os novos que estão aí, né, tem que juntar e conversar bastante, e já dá apoio pra gente. Vem gente assim de fora, já sabe o quê que vai fazer. Que nem o Tupã, que já sabe o que é que vai fazer. É, principalmente, sempre que eu falava assim pros povo daqui, pra comunidade falando, 'vocês não podem esquecer o Nhanderu. Esqueceu o Nhanderu e pronto, aí já... vira a cabeça não sei pra onde".

Como exemplo de história pessoal que leva à aquisição de conhecimento e, então, à liderança, há o caso de Tupã Mirim. Após acompanhar internações e tratamento de um filho recém nascido, o qual acabou falecendo, passou a dedicar- 
se ao cuidado da esposa, Tãtãxĩ, enteada de Karaí Poty, dando-lhe apoio para as viagens cotidianas da aldeia até o centro de Parelheiros, onde ela recebia medicação em um posto de saúde. Com o passar do tempo, Tupã Mirim começou a auxiliar outros membros da aldeia que necessitavam de orientação para fazerem uso da rede pública de saúde. Esse, segundo Tupã Mirim, foi o início de seu trabalho como liderança:

"O começo da... do trabalho da liderança começou assim. Aí depois dali já vem acompanhando, muitas vezes a gente participava assim da reunião do posto de saúde, o pessoal me chamava lá. Eu sempre participei assim da reunião. Aí a gente foi planejando como que a comunidade ia ser atendida lá".

Sua explicação para começar a ser liderança é exatamente igual às narrativas que contam como algumas pessoas, após superarem uma crise pessoal, geralmente ligada a uma doença grave, tornaram-se xeramõe (xamãs). 


\section{3 - Redistribuir o conhecimento}

Dentre os diversos elementos que devem compor o comportamento de uma liderança, a generosidade com a transmissão de conhecimento ocupa lugar de destaque. É muitas vezes uma dádiva divina, a qual deve entrar em circulação. $O$ que foi recebido generosamente das divindades deve ser generosamente redistribuído.

Diz Vera Mirim:

“Então essa pessoa assim que a gente [? 04'47"] liderança porque ele sabe das coisas, então o pessoal da comunidade não é que não saiba, mas ele entende assim mais é... vamos supor assim na parte política, então ele sabe mais do que a própria comunidade. Então ele vem, traz informações da cidade, ou das reuniões que ele participou, e a gente que fica mais na aldeia, então a gente... quando ele vem da cidade a gente participa, ele chama todas as pessoas e... conversa o que foi discutido nessa reunião. Então a gente chama todas essas pessoas de liderança, né”.

E também:

"Olha, ele é assim... é... Porque ele entende das coisas, então ele já foi cacique, depois se afastou e depois voltou a ser cacique de novo aqui, e... sempre... ele é respeitado. Então por isso que ele ao mesmo tempo é xeramoĩ e cacique também. Ele, ensina as lideranças mais jovens, né, como agir na defesa da comunidade. Então por isso que ele hoje é xeramoĩ e cacique”.

A distribuição de conhecimento não é generalizada. Nem todo o conhecimento circula em qualquer lugar ou é dado a qualquer pessoa. Transmitir uma informação que não deveria ser transmitida representa perigo, seja para quem a transmitiu, para quem a recebeu ou para aqueles contra os quais o conhecimento será usado. A responsabilidade com o uso do conhecimento aumenta na proporção em que aumentam os conhecimentos, assim, por exemplo, se um xeramoĩ revela o 
causador humano de determinada enfermidade em um indivíduo, certamente haverá retaliação e conflito.

Quando perguntei se a doença poderia ser mandada por outra pessoa, Vera Mirim respondeu:

"Olha, é... nesse caso assim eu não sei falar muito bem porque eu nunca... mas o... tem os pajés, né, os xeramoĩ tem... tem vários xeramoĩ, e são diferentes também, né, tem os que falam depois da reza, ou depois da cura, eles comentam, né, "ó, isso aqui foi feito por tal pessoas", mas o xeramoĩ José, ele é diferente de outras pessoas, pajés, ele faz a cura e só ele fica sabendo. Ele sabe se for no caso doenças espirituais, de espíritos da floresta assim, ele fala pra gente "você foi em tal lugar, e o espírito do rio não gostou muito que você foi lá, foi ele que fez essa doença assim", então quando é mandado assim, eu nunca... eu pessoalmente eu nunca ouvi ele falando, comentando, né”.

Há perigo para a transmissão de conhecimento quando os mais jovens se afastam dos mais velhos, tanto em relação àqueles que deveriam ter aprendido e não aprenderam, quanto àqueles que receberão um conhecimento sem a legitimidade necessária. Karai Poty comenta que algumas pessoas "não sabem contar história" porque não viveram o momento nem se interessaram por ouvi-la dos mais velhos. "Nem perguntavam pro pai, o mais certo é assim, né? Como é que eles vão saber a história?". Referia-se às pessoas que trabalharam fora da aldeia em que moravam e, assim, não acompanharam os mais velhos, pois "não tinham tempo" para ouvir suas histórias.

O lugar de liderança mais importante, na opinião de Pedro Macena, é o de xeramõe. Para estar no lugar de xeramõe, é preciso que se reconheçam nele qualidades que os Guarani traduzem como "conhecimento" (-mba'e kuaa) e "sabedoria" (-'arandu). 
"Mas, eu acho que quem lidera assim... tudo, tudo, tudo, é o xeramõe mesmo. Parte espiritual, a parte de organização, como que a gente vai viver, sempre respeitando o outro, respeitando o irmão, o parente, o sobrinho, né. Então todo esse conhecimento que a gente tem, é o xeramõe quem dá. Então [ele] leva o conhecimento pra gente porque, nós mesmo, a gente não sabe, como respeitar, como... Principalmente nossas crianças, então ele passa todo esse conhecimento pra gente, então [a gente] reconhece como pessoa líder".

Os conceitos -mba'ekuaa e 'arandu não se encerram na idéia de acúmulo de informações, mas incluem potências cuja origem é um amalgama de elementos derivados da agência do indivíduo, do contexto histórico e das estruturas que dão existência àquela posição. A história de vida de uma pessoa pode fazer com que ela passe por situações através das quais Nhanderu Ihes transmite conhecimento. Por exemplo, o esforço pessoal para a superação de um problema considerado grave como uma doença espiritual - é de alguma forma recompensado pelas divindades como através da revelação de eventos futuros, ou de uma proposta para a pessoa tornar-se um xamã e fazer curas.

Pedro Macena identifica elementos que rivalizam com essa característica da liderança, de transmitir conhecimento, fazendo com que os aconselhamentos sejam ignorados.

"Quer dizer, antigamente era mais... o pessoal acreditava mais, né, no que a gente falava e... é como você estava falando aqui de nós, que antigamente a gente contava história pras nossas crianças, nossas lendas. Aí as crianças tinham aquele medo, aí quando chegava a noite, umas seis horas, as crianças já dormiam. E hoje, não, hoje você conta uma lenda, uma história pras crianças ter medo e, tem nada, as crianças [dizem] 'isso aí é mentira, eu vejo isso aí na televisão, não sei quê' [risos]. Então é esse tipo de coisa que a criança acaba não acreditando na história que você fala, né, porque, as crianças já sabem que é... porque já assistiu na televisão, que vê aquilo... aquilo não é verdade, entendeu?" 
Ao referir-se à questão da "verdade", Pedro Macena aborda a própria função do conhecimento transmitido, que é a manutenção da vida. Assim, a mudança de referencial sobre o que é considerado verdadeiro é uma mudança que implica em perigo. Esse perigo afrontaria não apenas as pessoas, mas o próprio grupo, pois em meio a essa transmissão de conhecimento há o reforço dos vínculos (passados, presentes e futuros) entre as pessoas do grupo ${ }^{47}$.

“Então eles acham que a história também não é verdade, mas o que a gente conta pras crianças é verdade, entendeu? É uma lenda, é verdadeiro. Então a nossa história ela parte daquele... vamos supor que... nós temos nossos antepassados, que viveram, que a gente conheceu uma pessoa que viveu, que fez tudo aquilo, então aquela pessoa vai virar a história pra nós. Então a partir daquele... aí vira história. A gente vai contar 'não, no passado aquela pessoa viveu, fez isso, fez aquilo', entendeu? [risos]. Então vai virando história e com o passar do tempo então isso acaba virando lenda pra nós. Às vezes a pessoa andou e fez... alguma coisa engraçada, né, na aldeia, então depois que a pessoa, cinqüenta, sessenta anos ou oitenta anos depois, ou a pessoa já nem vive mais às vezes, então aquela pessoa acaba ficando na memória e na historia pra gente, então isso a gente acaba passando pras nossas crianças e pra os nossos jovens, né. Fala assim 'olha, vocês não viram mas a gente viu tal pessoa, tal índio lá, aqui que viveu aqui e fez isso', se fez bem a gente fala 'ó, ele fez bem, ele ajudou, ele foi uma grande pessoa, um grande...', mas quando fez alguma coisa errada que fez ou... aí a gente fala também pra ele 'fez isso, fez aquilo e acabou não sobrevivendo, podia estar hoje até aqui no nosso meio, mas não vive mais por causa disso'. Então a gente passa isso pra eles pra eles terem uma noção, pra eles pensarem, né, como que a gente possa viver bem aqui na comunidade, pra ele poderem ter um... guardar na mente deles pra que eles não possam cometer o mesmo erro que essa pessoa cometeu no passado".

47 "Grupo" e "pessoa", neste caso, não quer dizer exclusivamente "etnia" e "índio Mbya”, pois são lugares que definem as identidades em suas múltiplas relações com as alteridades. Por exemplo, um pai que fala a seus filhos sobre parentes que moram em outros lugares, uma liderança que fala de antepassados genéricos em uma reunião da aldeia ou um cacique que fala sobre a totalidade dos Guarani no Brasil em uma reunião com lideranças de diversas aldeias. 
Assim, a idéia de conhecimento também age sobre a temporalidade do grupo, pois o que contam às crianças, por exemplo, não se encerra na idéia de uma "história dos antigos", mas significa um conhecimento que garante a continuidade da existência, presente e futura. 


\section{4 - Posições de liderança}

\section{a) Xondáro}

Verá Mirim considera que seu trabalho como liderança começou com a sua participação nos grupos de xondaro, formados por kunumingué (jovens rapazes ainda não casados). Na aldeia de Rio Silveira participava dos grupos que faziam vigilância da área, com turnos diurnos e noturnos alternados, além de prestar auxílio à xejaryi, esposa do cacique Jijocó. Mudando-se para Tenondé Porã, buscou participar também como xondaro das atividades da aldeia, mas as tarefas do grupo organizado por Karai Poty eram parcialmente diferentes.

“[...] então o Xeramõe ajuntou todas as pessoas, kunumingué lá, e falou assim "a gente tem que fazer um grupo de xondaro", eu já tinha participado lá, né, do xeramõe Jijocó. Então a gente fez lá também, mas era tipo um trabalho interno assim. A Xejaryi precisava de fazer uma horta lá de mandioca, esse grupo ia lá, limpava a área e plantava com a Xejaryi. O Xeramõe precisava de plantar milho, então o grupo ia lá e plantava com ele. Cana, batata doce. Aí participava do movimento lá. Trabalhos comunitários também".

\section{Segundo Vera Mirim,}

"O xondaro é abaixo do oreruvixá, ele já é mais na... ele é uma pessoa escolhida também, a própria comunidade escolhe, porque quando na hora de trabalho ele vai lá, acorda cedo, vai lá, ele ajunta o pessoal pra fazer o trabalho comunitário, coordena a parte da cozinha, na parte da alimentação ele que coordena, ele é o xondaro. Mas mesmo assim a gente chama de xeruvixá também, né. Ele faz a liderança no trabalho". 
Vietta (1992) assim caracteriza o papel dos policiais: são responsáveis pela manutenção da ordem interna da aldeia; em geral, ocupam-se dos problemas gerados pela bebida, mas não têm poderes para punição; intervém em brigas e aconselham os contendores.

Karai Tataendy (Pedro Macena) contou que quando Karai Poty assumiu como cacique na aldeia Tenondé Porã, a função dos xondáro também mudou, passando de algo próximo aos policiais descritos por Vietta para uma função ligada à religiosidade do grupo. Assim, ao descreverem o xondáro, também falam da sua participação nos rituais na opy.

O xondáro, enquanto canta e dança, está amplificando o poder de comunicação do xeramõi com as divindades. Por isso, muitas vezes enquanto os xondáro ruvixa organizam e conduzem os trabalhos dos xondáro, o xeramõi fica deitado, no fundo da opy, concentrando-se. Disse-me Karai Poty que, nesse momento, ele está recebendo o conhecimento que os deuses lhe enviam através dos xondáro e xondária. 


\section{b) Xondáro ruvixa}

O xondáro ruvixa ("líder dos xondáro") é uma pessoa que exerce liderança em um grupo de xondaro, seja em trabalhos comunitários, na proteção da aldeia, na manutenção da "ordem interna" ou nos rituais realizados na opy.

Geralmente, essas funções são exclusivas, com uma liderança exercida em grupos específicos de xondáro. Assim, uma pessoa considerada xondáro ruvixa pela condução dos xondaro na opy não é necessariamente a mesma que acompanha o grupo de vigilância da aldeia. Assim como os grupos de xondaro também não necessariamente compostos pelas mesmas pessoas em tarefas diferentes, ou seja, há os xondáro que preferem o trabalho de vigilância a outros tipos de trabalho.

Wiliam Macena explicou que seu irmão mais velho, Mário

é [mais ligado ao campo da espiritualidade do que às relações com os jurua] porque ele ajuda, né, então, pajé, como no caso do Xeramõe, ele tem que ter uma pessoa, né, assim que uma pessoa que ele faz a primeira reza numa pessoa. Porque o Xeramõe ele é assim: ele não vai ele primeiro fazer a reza, né, então primeiro ele faz a reza, no caso o seu Mário, né, é que ele faz, vamos dizer assim, uma limpeza, então no caso assim, se for muito grave, ele coordena os xondaro, os jovens assim. [...] Xondaro ruvixá, que no caso seria xondaro... a gente fala xondaro assim que... mas sempre tem que ter uma liderança, né, que seria o uvixá, seria xondaro ruvixá. Ele que está coordenando os xondaro. Então o seu Mário é mais na parte desse trabalho.

Além de Mário Macena, participam dos rituais cotidianos cumprindo essa função os filhos de Karai Poty, Pedro Fernandes e Vitor Fernandes, além de Ronaldo Costa, um jovem rapaz que quase sempre faz o canto/reza inicial, antes do xeramõi. 
É também como Tupã Mirim descreve o trabalho de um falecido tio, afirmando que ele

“[...] era uma pessoa líder, né, uma pessoa que na época não era pajé ainda, o finado meu tio. E... ele ajudava os cacique lá, pajé, fazer organização, organização dentro da cultura indígena, não associação, de um trabalho, de fazer assim um projeto, não é assim. A gente fazia... nossa organização sempre tinha, mas que essa pessoa vai de casa em casa, pegar a pessoa, levar pra fazer mutirão. [...] comunidade indígena sempre tinha mutirão. Mutirão é um serviço comunitário. Então eles faziam um dia de trabalho pra uma família, um dia de trabalho pra outra família, assim vai indo". 


\section{c) Uvixa}

Uvixá, nhanderuvixá ou oreruvixá ("nosso líder") também podem ser usados como sinônimos de xeramõe quando o uso tem a conotação de "o mais respeitável", "venerável". Mas em muitos casos há evocação do termo quando da necessidade de se referirem a qualidades de "liderança", "chefia" ou "mando".

O poder de mando se baseia no respeito e, portanto, na crença daquele que recebe a ordem de que ela deve ser cumprida - diferentemente do poder do Estado, assentado no o uso da força, cuja legitimidade é reconhecida. O poder do -uvixá emana do mandado, mais do que do mandatário.

Mas isso não significa que não haja uso da força em determinadas ocasiões. Por exemplo, no caso de controle do uso excessivo de bebidas alcoólicas: um cacique (que é um uvixá) pode mandar xondaro para aplicarem surras em pessoas que causem desordem ou provoquem brigas por estarem alcoolizadas.

Outro momento quando o poder de mando é exercido com o uso da força é no treinamento dos xondaro, quando o xondaroruvixá testa a disciplina dos kunumingué (rapazes, em geral solteiros, para cuja tradução o termo "adolescente" é às vezes usado pelos Mbya).

A liderança exercida pelo uvixá, no entanto, é idealmente baseada no respeito, fruto do reconhecimento pelo grupo de que ele é detentor de sabedoria e conhecimento - sinais não apenas da experiência em determinado assunto, mas principalmente de que possui forte canal de comunicação com as divindades.

Tais qualidades, reconhecidas no uvixá, indicam que reúne condições de ser aquele que "segue à frente", mostrando o caminho, pois além de ter experiência de 
vida e de saber ouvir os deuses é preciso ser generoso, transmitindo seu conhecimento e sabedoria - dádivas divinas recebidas que precisam entrar em circulação.

“Então, diz Pedro Macena, nhanderuvixá é... pra nós é... é como eu falei, nhanderuvixá é tudo, né. É ele que dá esse trabalho, esse caminho, esse conhecimento ele passa, pra gente estar... poder se organizando, de modo tradicional. Então, nhanderuvixá que dá toda essa... esse conhecimento. Passa tudo isso pra nós".

Transmitir conhecimento é uma qualidade indispensável para o uvixá, seja um xeramõe ("xamã"), um xondaroruvixá, sendo necessário para tanto que o grupo reconheça nele tal qualidade. Isso implica, nesse caso, que o grupo de idade a que pertence não é determinante.

"Pode ser um rapazinho de... dependendo se estiver num grupo de jovens que ele que está passando esse tipo de conversa, o que ele aprendeu com o xeramõe está passando pra eles [os outros jovens], então ele é um xeruvixa, ele está contribuindo dentro da comunidade. Ele tem essa visão de levar esse conhecimento, o que ele vê, o que ele acha".

Essa informação de Pedro Macena é corroborada por uma outra que tem circulado a respeito de um jovem rapaz (kunumingué), de uma das aldeias da capital, que tem demonstrado impressionante capacidade, segundo os próprios Guarani, de conduzir os rituais na opy.

Segundo Oliveira (2002), é papel do cacique lidar com as questões relacionadas ao juruá, o branco. Em Bracuí (RJ), entretanto, o cacique Verá Mirim transfere essa tarefa ao vice-cacique, que "cuida dos projetos e reuniões com os juruá, das relações branco/índio no sentido de administrar as perdas e danos 
causados aos Mbyá" (idem:41). O cacique então sente-se livre para dedicar-se aos problemas internos, como os conflitos gerados pelo abuso de bebida alcoólica.

Essa divergência apontada por Oliveira em relação à função do cacique é justamente porque é uma palavra adaptada à realidade mbya, da mesma foram que a palavra "capitão". Assim, à luz do que pôde ser verificado no Tekoa Pyau, essa ambigüidade é esclarecida. Uvixa designa genericamente "liderança" e, portanto, não desempenha uma função única. Há várias possibilidades de se ser uvixa, como o que conduz os xondáro, como ser o cacique que administra problemas internos à aldeia (ou estende sua influência a outras aldeias dependendo da articulação das alianças que pode estabelecer) ou trata de questões ligadas aos jurua. Em toda essa pluralidade de funções, a unidade se estabelece na esfera do comportamento esperado, do modo de ser, o tekó.

Vietta (1992) ao descrever o papel de lideranças entre os Mbya no Rio Grande do Sul, aponta para a existência de múltiplas posições que têm umas às outras como referência para sua função. Assim, resumidamente, há o conselheiro, cuja função é basicamente aconselhar os membros da aldeia, através dos discursos, tendo como referência o sistema de valores Mbyá; o capitão, que além de preocupar-se com a manutenção dos valores tradicionais, auxiliando o conselheiro e o cacique, é o representante da aldeia junto a comunidade não-índia do entorno e junto às agências governamentais e não governamentais que ali intervém; muitas vezes, para lidar com situações que extrapolam os limites da aldeia, a liderança escolhe uma comissão, na qual o capitão sempre está presente; e o cacique, que é o membro mais eminente da liderança, responsável exclusivamente pelas questões internas; zela pela manutenção dos valores tradicionais, ao lado do capitão e do 
conselheiro, e pela manutenção da unidade do grupo; também cuida das questões administrativas.

Luciane O. Ferreira (2001), em sua dissertação de mestrado, discute a noção de doença para os Mbyá com base em sua cosmologia e, ao mesmo tempo, considerando a relações que estabelecem com outros índios ou com não-índios. Nesse trabalho, a autora faz referência principalmente a dois componentes da liderança dos Mbyá: o karaí, um misto de líder religioso e médico tradicional, e o Representante, assim descrito pela autora: tem algum vínculo com o karaí da aldeia, e o seu apoio espiritual, deve ter o apoio político de seu grupo familiar e ser legitimado pela comunidade, e é necessário que "a pessoa tenha 'nascido para isso', que seu 'espírito' tenha sido enviado por Deus para exercer tal função" (p.53); Deve, ainda, ser forte, pois ao exercer a função, sofre ação espiritual negativa (portanto, adoece), tanto pelo contato com os brancos e seu mundo, como pelo feitiço enviado por parentelas insatisfeitas com seu trabalho (p. 56-57).

No Tekoa Pyau, um chefe de família extensa também pode ser chamado de uvixa ou de xeramõi (oreramõi). Nesse caso, a forma de tratamento é determinada pela sua posição no interior da família extensa. Em muitos dos casos são homens mais velhos, que mantiveram junto a si seus filhos e filhas casados e seus cônjuges. Contudo, é possível que haja ali homens idosos, os quais, pelo parentesco ou por reverência, são chamados de xeramõi (avô), mas não necessariamente desempenham o papel de uvixá ou de xeramõi (xamã).

Assim, segundo Vera Mirim

“[...] uvixavé seria liderança, né, então ele que coordena todos os trabalhos internos da comunidade, então, quando alguém precisa de roça ele primeiro é procurado, então depois é ele quem passa pra comunidade ajudar, fazer a roça, fazer as plantações, então ele que é mais 
procurado, né. Agora, a gente chama de oreruvixá. Oreruvixá, seria o 'nosso chefe', né, ele que coordena toda a... uma aldeia, né".

\section{E completa:}

"[...] Então, é... no caso do pajé já é diferente, aí já é xeramõi. Xeramõi já é mais do que pajé, mesmo, mais na parte espiritual, na parte espiritual, de conselho, conselho espiritual, né. Agora oreruvixá aí já é na parte mais política dentro da aldeia, faz aconselhar e também cuidar das atividades de trabalho". 


\section{d) Xeramõi}

"O xeramõi... o oreramõe é uma palavra... é... que assim. Oréramõe é uma pessoa como se fosse o Nhanderu mesmo, que os nossos antigos chamavam de nhanderu. nhanderu, oreru, "nosso pai”, aí seria mais pro 'pajé' que o juruá fala, né”, disse Vera Mirim.

Xeramõi, no entanto, não é apenas sinônimo de xamã. Também é um indicativo de que a pessoa é portadora de conhecimentos ligados à administração da vida coletiva e cotidiana, implicando em oferecer alternativas a questões como a organização espacial da aldeia (ou de seu núcleo familiar), a obtenção de alimentos ou a resolução de conflitos. Segundo Pedro Macena, um xeramõi é

"[...] a pessoa que tem mais conhecimento, nós também chamamos de líder, né, então é assim, uma pessoa que tem conhecimento, que sabe das coisas, o quê que ele... o quê que está faltando, né, o quê que tem que fazer pra melhorar cada vez mais... pra fazer... então ele é pessoa assim que tem visão das coisas. Então essas pessoas que são... prá nós é liderança, né".

O termo xeramõi é usado para se referirem genericamente às pessoas mais velhas, uma forma de tratamento respeitosa ${ }^{48}$. Em Dooley (1998) o termo também significa "antepassado", no entanto, no tempo em que estive em campo não notei seu uso diretamente com essa denotação, mas sempre acompanhado de complementos como yma ou araka'e, "antigamente". Também significa "meu avô" (FF ou MF).

Segundo Oliveira (2002:41), o cacique da aldeia de Bracuí Vera Mirim, é também o nhanderú, ou seja, o líder religioso, que pode lançar mão de diversos

${ }^{48}$ tujá também pode usado, mas não tem o sentido de reverência que xeramõe evoca, relacionando-se mais com a condição de ser "velho" ou "mais velho". 
meios para acessar a sobrenatureza (cachimbo, cantos, plantas, sonhos) e o opyguá ${ }^{49}$, o responsável pelo opy (a casa de rezas).

Um xeramõi (xamã) é sempre um uvixá, mas o contrário não é verdadeiro. Aquelas qualidades da liderança são as mesmas do xeramõi, no entanto, há variações em grau e em qualidade. Um uvixá (liderança) deve idealmente: ter conhecimento e sabedoria reconhecidos pelo grupo, assim como a capacidade de transmiti-los; estabelecer uma comunicação eficiente com as divindades; liderar as pessoas pelo convencimento, evitando/superando conflitos com ou entre elas.

No caso de um xeramõi, essas qualidades são multiplicadas justamente por relacioná-las e entrecruzá-las mais intensamente. O xamã tem conhecimento e sabedoria originados pela sua experiência de vida e trabalho, pela sua relação generosa com as pessoas e, principalmente, pela sua capacidade de se comunicar com as divindades e com os seres sobrenaturais em geral. Ao mesmo tempo, a relação com os deuses e com seres sobrenaturais como os "donos" de animais, plantas, pedras, rios etc., tem muitas vezes como origem a necessidade de se obter benefícios para o grupo (como a cura de doenças espirituais ou dádivas enviadas por meios diversos - p.e. evangélicos juruá que aparecem na aldeia para doar cestas básicas), fazendo com que o grupo reconheça no xeramõe sabedoria e conhecimento importantes para sua existência. Igualmente, um grupo se forma em torno de um xeramõe (podendo ser mais amplo que sua própria família extensa) pela capacidade dele se relacionar com os deuses, por ser portador de conhecimento e sabedoria, pela capacidade dele se relacionar generosamente com

${ }^{49}$ Vietta (1992) registra que karaí-opygua é o grande líder religioso com ascendência sobre diversas parentelas a ele ligadas, mesmo que residentes em aldeias diferentes. Karaí é também o grande xamã e líder de migrações religiosas descrito por H. Clastres (1978). 
as pessoas e de estabelecer alianças com outros grupos (famílias extensas, aldeias, juruá kuéry).

Vietta (1992) descreve um karaí-opyguá ("grande rezador") como um cacique e um xamã de destaque cuja atuação extrapola os limites de uma única aldeia; sua influência abrange todas as parentelas a ele ligadas, independentemente de onde se encontrem ${ }^{50}$, as quais formam o seu grupo grande.

O cacique, segundo a autora, é uma espécie de representante do karaíopyguá na aldeia, voltado às questões administrativas, enquanto o grande rezador é o principal responsável pela ligação do grupo grande com as divindades.

Assim, um uvixá que lidera ou acompanha projetos em uma aldeia pode ter força suficiente para manter relativamente coesa uma família extensa em um núcleo de residências, baseando-se principalmente no fato de ser provedor de recursos e benefícios através do trabalho que desenvolve. Pode até mesmo ser escolhido como cacique da aldeia. Mas seu conhecimento sempre será considerado limitado em comparação a um xeramõe (xamã), a quem pode ter que eventualmente recorrer para aconselhamento. $\mathrm{Na}$ avaliação de Karaí Poty, os caciques que não participam dos rituais na opy, não cantam e não dançam são mais fracos, pois se esquecem de Nhanderu. Portanto, a inversão lógica dessa consideração do cacique nos informaria que as lideranças políticas mais fortes são as que estão mais envolvidas com a espiritualidade do grupo: os xeramõe.

${ }^{50}$ A autora cita o exemplo do cacique Joancito, cuja influência abrangia as aldeias do Rio Grande do Sul, do litoral de Santa Catarina e do Paraná, além de aldeias na Argentina - todas ligadas a ele por meio das parentelas; também acumula a função de cacique da aldeia de Barra do Ouro (RS). 


\section{Capítulo V}

\section{Conclusão}

A história de São Paulo estaria incompleta sem levar em conta a história da sua relação com os povos indígenas; dos portugueses e bandeirantes dos primeiros séculos, aos paulistas da atualidade, as relações permanecem produzindo eventos cujos desdobramentos apontam para o surgimento de novos eventos, novos desdobramentos e novas relações a se estabelecer.

Em meio à diversidade de relações que os contextos implicam, uma é recorrente: a que se estabelece entre o Estado e os povos indígenas. Sem me estender no assunto, apenas chamo a atenção para esse fato, pois nos ajuda a entender o contexto específico do surgimento das atuais aldeias Mbya no Jaraguá.

A formação do Parque do Jaraguá, como um ato do Estado brasileiro em São Paulo, implicou na abertura de uma oportunidade para que índios Guarani viessem a se estabelecer ali a partir de meados do século passado. Tal oportunidade não era vazia de significados, ao contrário, era fruto uma determinada interpretação da história da ocupação colonial, que apontava não exatamente para a existência de uma relação histórica com os índios, mas para a superioridade daqueles que os sucederam definitivamente: nas intenções de alguns dos idealizadores dos projetos em torno do parque, a presença daqueles índios teria a função de produzir um cenário animado, em movimento, do passado do paulista, ou, do seu mito de origem.

O lado perverso da ideologia subjacente a essa recomposição da história é a tentativa de se reafirmar o apagamento da presença indígena da história recente da região, uma vez que a historiografia oficial já os tratava apenas como parte do 
passado - a iconografia quinhentista seria mais viva do que as aldeias contemporâneas em São Paulo.

Ao mesmo tempo em que os Guarani em São Paulo foram diretamente afetados por essas interpretações da história (pois que influenciaram as políticas de Estado), a história de suas relações internas produziu eventos que os levaram a ser notados (pois que os levaram a reocupar espaços antes conquistados pelos colonizadores). Fracionamentos e recomposições de grupos familiares, mobilidade e uma noção própria de espacialidade foram alguns dos elementos que participaram e participam - das agências desse grupo indígena na cidade. É o que levou à formação da aldeia Tekoá Ytu e, posteriormente, como veremos nos próximos capítulos, à formação da aldeia Tekoá Pyau.

O processo que levou à formação da aldeia Tekoa Pyau tem, evidentemente, suas especificidades, principalmente em comparação com o conjunto de eventos que levaram à formação do Tekoa Ytu. No entanto, chama a atenção o fato de que, em meio à multiplicidade de acontecimentos, alguns elementos se repetem em ambos os casos, assim como provavelmente o seria revelado pela história de formação de outras aldeias. Dentre esses fatos está a relação entre parentesco, espacialidade e religiosidade.

Esses três elementos combinaram-se no transcorrer da história mbya do Jaraguá, dando lugar a uma situação ainda desconhecida por muitos paulistanos: a existência de aldeias de índios Guarani junto ao Pico do Jaraguá. Foram as relações de parentesco que levaram a família de Joaquim e Jandira a procurar um outro lugar para morar. Da mesma forma, foi o parentesco entre Jandira e José Fernandes, e as relações que estabeleceram entre si no local, que formaram a pedra de fundação da aldeia Tekoa Pyau. 
A noção de uma espacialidade que não se encerra em aldeias, mas segue as trilhas dos parentescos e das alianças deu condição para que a mobilidade (característica desse grupo indígena) repartisse famílias em outros locais para que estas ali se juntassem.

Assim, é possível inferir que é essa forma de relação entre famílias extensas, parcialmente sobrepostas, mas desiguais em tamanho e prestígio, que cria o pano de fundo para permitir a existência da hegemonia de uma família principal. Ao mesmo tempo, essa mesma estrutura contribui para a geração de rompimentos, com a conseqüente mudança de grupos familiares para outras áreas, e sua possível absorção por outra família extensa já instalada no local.

A agência politicamente orientada de Karai Poty, é própria do lugar que ocupa como xeramõi (xamã), e é o que vem tornando seu grupo cada vez mais importante nas relações com os Mbya de outras aldeias. A atuação do xamã percorre os caminhos do parentesco, o que é indicado pelo próprio uso do termo xeramõi, que também significa "avô" e pode ser uma referência ao chefe de família extensa, dos quais, por sua vez, o grupo espera um comportamento referenciado no tekó, principalmente no que diz respeito à relação estabelecida com as divindades. A atuação do xamã também percorre os caminhos das alianças, que são produzidas por meio dos rituais de cura em outras aldeias (as pajelanças) - mesmo de outros xamãs ou chefes de família, como o faz Karai Poty - e pela participação nos rituais de nominação, para os quais é convidado.

E o crescimento e o fortalecimento dessas aldeias tiveram como pano de fundo, além da mobilidade e do parentesco, as relações estabelecidas através da religiosidade, exercida por meio de lideranças religiosas que criaram ou fortaleceram alianças com diversos grupos familiares. No caso de José Fernandes, por exercer a 
função de xeramõi, um xamã com agência política, cujo trânsito se dá tanto pela natureza e pela sobrenatureza, como pela sociedade. No caso de Joaquim, por ocupar uma posição reservada aos xamãs, que é o da pessoa que produz a cura (afinal, era responsável por conduzir parentes doentes para os hospitais, assim como foi responsabilizado pela morte de um deles, da mesma forma como o são os xamãs).

Assim, o xamã constrói alianças fundadas no reconhecimento de suas capacidades xamânicas, as quais por sua vez são potencializadas pelo reconhecimento, por parte das divindades, de suas boas práticas, as quais tem como balizador o tekó, o modo de ser guarani.

Ao mesmo tempo, os resultados positivos na obtenção de recursos (alimentos, financiamento de projetos, construção de escola, posto de saúde etc) estão também ligados ao fato de estabeleceu alianças com grupos familiares e pessoas capacitados para lidar com agências e burocracias não indígenas. A instrumentalização e capacitação desses aliados é fruto tanto de suas próprias histórias de vida quanto pela convivência com Karai Poty, que atraía projetos para a área e solicitava a estes aliados que os desenvolvessem, reforçando assim o processo de seu aprendizado.

Os Macena, como já foi dito, têm experiência em lidar com os não Guarani, envolvendo-se em projetos de implementados por ONGs na aldeia, fazendo seus próprios projetos, e administrando recursos financeiros. São, assim, uma presença importante, e aliados de primeira hora. Karaí Poty sabe da importância desse grupo - o qual, como já foi dito, não constituiu um núcleo de residências próprio no Tekoá Pyaú - e assim tem convidado ainda outro dos irmãos (FBS, primo) Macena, Jango, uma das lideranças na aldeia de Parati-Mirim (RJ), para morar no Jaraguá. 
Jango, entretanto, tem resistido a sair de Parati-Mirim, uma aldeia cravada na Mata Atlântica, com acesso a recursos como plantas medicinais e para artesanato, com riachos e cachoeiras limpos e relativamente distante dos Juruá. Disse-me ele que ainda não trocaria o lugar em que mora atualmente pelo Jaraguá. Nunca foi lá, mas disse saber da situação difícil e da precariedade da área.

No período em que estive em Parati-Mirim, também estava lá Ivandro, morador do Jaraguá que é genro de Jango. Ele estava com uma "doença espiritual", e aguardava a chegada do pajé da aldeia para que pudesse curá-lo. Jango, em uma conversa no quintal de sua casa, disse que pretendia convidar seu genro para ficar na aldeia. Evandro, ao menos por enquanto, disse preferir ficar no Jaraguá, pois há muito trabalho apenas começado e que gostaria de terminar - há um projeto relacionado a produção de um vídeo na aldeia, além disso, ele parece ser uma espécie de assessor de imprensa, pois quase toda entrevista na aldeia é encaminhada para ele.

A política de atração de aliados não é exclusiva de Karai Poty, mas própria da posição de lideranças que têm como projeto o fortalecimento de sua família extensa. Karai Poty, no entanto, parece exercer um poder de atração muito maior do que outros chefes de família extensa. A área do Tekoá Pyaú, passou de cerca de trinta pessoas em 1998 para mais de trezentas, em 2008 - apesar do tamanho da aldeia, com 2,5 hectares.

Assim, pelo que foi observado, a hegemonia política de uma família extensa parece ser obtida com um duplo movimento: a) pela arregimentação de aliados que contribuem para a melhoria das condições da aldeia, b) sem, contudo, dar-Ihes condição para que componham uma família extensa suficientemente forte para competir com a sua própria família. 
Um exemplo de que esse controle é efetivo é o movimento realizado, por parte de um cacique de uma das aldeias visitadas, para tirar seu genro de um cargo que the dava bastante prestígio na escola da aldeia. Esse genro pertence a uma outra família extensa da área, organizada em um núcleo de residências sob o comando de um chefe de família extensa, e era um dos poucos membros dessa família a fazer parte da chamada "liderança" da aldeia. Ao mesmo tempo, o cacique permitiu que outro genro, irmão do primeiro, obtivesse empregos para parentes bastante jovens, que vieram de aldeias distantes, nessa mesma escola. O resultado final foi que a família extensa em questão deixou de ter um membro importante em um lugar de prestígio, mas não sentiu com isso impacto na perda de recursos.

No Tekoa Pyau, a relação entre as famílias aqui apresentadas parece ser diretamente influenciada pela intersecção entre:

\section{1) histórias pessoais:}

a) dos Macena, que os levaram a assumir responsabilidades nas aldeias em que moraram por iniciativa própria, ou a sofrerem de certos males para a resolução dos quais necessitaram da intervenção de Karai Poty, a quem passaram a acompanhar;

b) de Alizio, que se instrumentalizou pela educação escolar após uma situação inesperada ver-se perdido quando recém chegado a São Paulo; que se envolveu com questões ligadas à saúde após uma tragédia pessoal; e que acumulou experiência também como vice-cacique na aldeia da Barragem para a função que hoje exerce como presidente da associação; 
c) e de Karaí Poty, que acumulou grande experiência nas discussões sobre demarcação de terras, foi cacique em todas as aldeias onde morou, e manteve uma importante rede de contatos com os não índios.

2) as posições na organização social que colocam em relação:

a) sogro (Karai Poty) e genros (Wiliam e Alizio); e

b) xeramõe (Karaí Poty) e seus "seguidores" (Pedro e Mário).

3) a história e a estrutura dos grupos familiares responsáveis por:

a) suas composições, como a quantidade de membros e os tipos de laços de parentesco internamente estabelecidos;

b) suas posições em relação ao conjunto de famílias da aldeia (se formam ou não um núcleo de residências diferenciado);

c) alianças estabelecidas com famílias da aldeia ou de outras aldeias (se já formavam um grupo diferenciado em outra aldeia, se possuem parentes com prestígio outros locais).

Com esse quadro aqui apresentado é possível chegar a algumas conclusões. Primeiro, falar em família extensa não quer dizer necessariamente que se trata de um grupo homogêneo. Se por um lado é possível falar que há uma grande e principal família na aldeia, que é a de Karaí Poty, e que os Gabriel e os Macena são seus agregados, por outro lado, é perceptível que o núcleo residencial dos Gabriel não está inteiramente integrado ao do cacique, permitindo, assim, sua existência como um família extensa diferenciada. 
Mesmo a família Gabriel sendo numericamente maior que a família Fernandes, seu peso político nas reuniões coletivas e a sua participação nas atividades são bastante menores. Nesse caso, um elemento parece fazer a diferença: a posição de Karai Poty como liderança religiosa.

Se pensarmos os lugares dos uvixa como identidades, há que se pensar nas relações que estabelecem com as alteridades, pois são essas relações que os determinam. A aldeia não é uma totalidade homogênea, com lugares de liderança preenchidos por certos indivíduos igualmente reconhecidos como tal por todos os seus moradores.

O que venho chamando de "grupos" são, na verdade, uma diversidade de grupamentos com características, funções e significados também diversos: pessoas de uma mesma família, moradores de um mesmo núcleo de residências ${ }^{51}$, participantes de um ritual específico ou dos rituais cotidianos, participantes de um grupo de vigilância ou de um grupo de trabalho. Dessa forma, sendo diversos os grupos de liderados, diversas são as possibilidades de reconhecimento das lideranças. É o que explica, por exemplo, porque determinada pessoa pode ser considerada uvixa ao liderar o desenvolvimento de projetos, mas não ser citada quando alguém pergunta quem são as "lideranças da aldeia".

Mas também é preciso considerar que a resposta depende não só da relação liderança/liderado, mas também da que se estabelece entre a pessoa a quem se faz a pergunta e a que a está fazendo. Por exemplo, em uma visita à aldeia, engenheiros da Sabesp ${ }^{52}$ perguntaram a um rapaz quem era o chefe com quem eles

${ }^{51} \mathrm{O}$ núcleo de moradias pode incluir não apenas parentes, mas também "agregados", como os parentes de um genro ou de uma nora, os seguidores de um xeramõe (xamã) ou de um uvixa que é provedor de recursos diversos.

${ }^{52}$ Estatal responsável pelo saneamento básico no estado de São Paulo. 
poderiam falar. O rapaz respondeu que chamaria ao presidente da associação. Mas outro rapaz estava junto e, sem dizer nada, foi à casa do cacique para chamá-lo. 0 primeiro avaliou que aquela era uma situação que caberia ao presidente da associação resolver, pois os juruá tinham vários kaxia ("papéis") nas mãos, indicando que era um problema burocrático em questão. $\mathrm{O}$ outro, ao saber que eram engenheiros de uma instituição do governo entendeu que caberia a intervenção do uvixa da aldeia (o "cacique").

Contudo, há situações que levam a convergências próximas da unanimidade, como no Tekoa Pyau, onde a liderança de Karaí Poty é reconhecida por quase toda a aldeia, tanto no campo da religiosidade como do que poderíamos chamar de administração do cotidiano. Neste caso, o que converge é consenso em torno de um comportamento considerado ideal.

A formação de uma liderança depende de sua disposição para acompanhar as lideranças da aldeia onde está, oferecer-se para ajudar, mostrar que está disposto a aprender, que não teme disciplinas rígidas e que valoriza a palavra dos mais velhos. "Por isso que a gente vai assim... acompanhando o chefe, né, vai aprendendo, mas para ele mesmo, não é para os outros que vai aprendendo", diz Karaí Poty. Ou seja, não se trata simplesmente do "aprendizado de um ofício", mas de trazer para o indivíduo mais elementos que o aproximem do ideal de pessoa Mbya, que são aqueles que constituem as qualidades reconhecidas na pessoa do xeramoĩ.

A vila de São Paulo, que virou cidade e depois essa imensa metrópole veio se aproximando da região do Jaraguá como um tsunami que viajou na velocidade dos séculos. Os Guarani das atuais aldeias no Jaraguá sentiram o maior impacto dessa 
chegada justamente quando essa aproximação ocorreu maior velocidade e intensidade, a partir de meados do século passado. Daí a impressão que temos, quando vemos as fotos, de que aquelas aldeias indígenas são ilhas constituídas em meio ao ambiente urbano. Não o são na história, pois que foi a cidade que se aproximou e tomou os espaços que os Guarani já antes utilizavam. Também não o são nas relações que estabelecem com o seu entorno, pois ali, a cidade fornece a subsistência material, e diversas possibilidades para a constituição de diferentes identidades e alteridades - ou ao menos um bom material para a reflexão dos grandes pensadores guarani, com os quais tive o prazer de conviver. Mas a história e a etnografia dessas relações ainda estão por ser feitas.

As relações focadas pela pesquisa dizem respeito às que são estabelecidas entre os próprios Guarani Mbya. Ao reconstituir a história das aldeias e ao realizar a etnografia em uma delas, uma multiplicidade de grupos surgiu, relativizando as generalização "os Guarani”. Formam-se, antes, redes de grupos entrelaçados pelo parentesco e pelas noções de espacialidade e de pessoa. Dentre esses grupos, estão os núcleos de residências, famílias extensas, tekoa, e aqueles organizados para trabalhos específicos como os em roçados ou para limpeza da aldeia, para o desenvolvimento de projetos ligados a agências não indígenas, para a realização de rituais na opy. Associações com maior ou menor duração, o fato é que, ao mesmo tempo em que nenhum grupo é contínuo ad aeternum, todos eles fazem referências àquelas noções, compartilhadas por todos os Mbya.

Tomando como ponto de vista o lugar das lideranças foi possível perceber a pluralidade de posições a que o termo liderança se refere e, através delas, perceber pluralidade de posições com as quais se relacionam, como xondaro e xondaro ruvixa, uvixa e xeramõi. E assim, com mais uma "volta do parafuso", vieram à tona 
relações que antes pareciam constituir oposições, mas que se revelaram complementações, como no caso de xamãs e lideranças políticas. Por fim, foi possível perceber que a pluralidade de grupos e posições sociais se funda em um conceito: o tekó.

Esse termo, bastante conhecido na literatura etnológica guarani, é traduzido como "modo de ser" ou "sistema". Num sobrevôo por essa literatura, encontramos como elementos relativos ao tekó: a reciprocidade (em oposição ao individualismo e à avareza); a língua (e a língua sagrada dos rituais); os casamentos endogâmicos (entre Mbyá); a evitação da violência (ou a sua condenação como atitude animal e não-divina), os rituais cotidianos (e a comunicação com as divindades); preocupações ecológicas e escatológicas (fim do mundo e a Terra Sem Mal); distanciamento (do branco); cuidados alimentares e não ingestão de bebidas alcoólicas (conf. Schaden, 1974; Clastres, 1978; Oliveira, 2002; Guimarães, 2001; Vietta, 1992; Ladeira, 1992; Chamorro, 1999).

Somente através da observação do tekó é possível transcender e transformar-se na pessoa ideal, que é a própria divindade - e quem representa essa possibilidade é o xamã (karai, xeramõi, nhanderu), não apenas porque é um "guardião" dos costumes, mas porque é nele que se vêem, pelo grupo, aquelas qualidades.

Assim, se, por um lado, a ascese é necessária para se atingir esse objetivo, ela não implica em negação da sociedade. Pois é a própria sociedade que constrói o lugar dessa pessoa ideal. O xeramõi é, ao mesmo tempo, constituído pelas referências coletivas formadoras tanto do campo da religiosidade quanto do campo da política. 


\section{REFERÊNCIA BIBLIOGRÁFICA}

ALMEIDA, Rubem Ferreira Thomaz de. Do desenvolvimento Comunitário à mobilização política. O projeto Kaiowá-Ñandeva como experiencia antropológica. Rio de Janeiro: Contra Capa, 2001.

BARTOLOMÉ, Miguel Alberto. Chamanismo y religión entre los Ava-Katu-Ete. Assunção, Paraguai: Centro de Estudios Antropologicos, Universidad Catolica, 1977 [1991].

CALIXTO, Benedicto. Os primitivos aldeiamentos indígenas e índios mansos de Itanhaém. In: Revista do Instituto Histórico e Geographico de São Paulo. Vol. X, 1905. São Paulo: Typographia do Diario Official, 1906. (texto escrito em 1902). p. 488-505.

CARNEIRO DA CUNHA, Manuela. História dos Índios no Brasil. São Paulo: Companhia das Letras/Fapesp/Smc, 1992

CADOGAN, Leon. Ayvu Rapyta: textos míticos de los Mbyá-Guarani del Guairá. Boletim de Antropologia da Universidade de São Paulo, 1959.

CHAMORRO, Graciela. La restitución de la palabra. Suplemento Antropologico: Revista del centro de estúdios antropológicos. Assunção, Paraguai: Universidad Catolica, vol. XXXIV, № 2, p.101-121, 1999.

CHEROBIM, Mauro. Os índios Guarani do litoral do estado de São Paulo: análise antropológica de uma situação de contato. São Paulo: USP, 1986.

CLASTRES, Hélène.. Terra Sem Mal: o profetismo tupi-guarani. São Paulo: Brasiliense, 1978.

CLASTRES, Pierre. A Fala Sagrada: mitos e cantos sagrados dos índios guarani. São Paulo: Papirus Editora, 1974 [1990].

Comunidades das aldeias Tekoa Ytu e Tekoa Pyau da Terra Indígena do Jaraguá \& Grupo Oim porã ma oré rekó. Avaliação do "Relatório de estudo etnoecológico da comunidade Guarany da Terra Indígena Jaraguá" referente ao Processo de Compensação da Obra Viária Rodoanel Mário Covas - Trecho Oeste. São Paulo: 2006. 
DALLANHOL, Kátia Maria Bianchini. Jeroky e Jerojy: por uma antropologia da música entre os mbyá-guarani do morro dos cavalos. Dissertação (Mestrado). Universidade Federal de Santa Catarina - UFSC, Florianópolis, 2002.

DOOLEY, Robert A. Léxico guaraní, dialeto mbyá: versão para fins acadêmicos. SIL: Sociedade Internacional de Lingüística. [revisão de novembro de 1998].

FERREIRA, Luciane O. Mba'e Achÿ: a concepção da doença entre os Mbyá-Guarani num contexto de relações interétnicas. Dissertação (Mestrado). Universidade Federal do Rio Grande do Sul, Porto Alegre, 2001.

GADELHA, Regina A. F.(org.). Missões Guarani: Impacto na Sociedade Contemporânea. São Paulo: Educ/Fapesp, 1999.

GUIMARÃES, Silvia Maria Ferreira. Os Guarani-Mbyá e a superação da condição humana. Dissertação (Mestrado). Universidade de Brasília - UnB. Brasília, 2001.

LADEIRA, Maria Inês. O Caminhar sob a Luz: o território mbya à beira do oceano. Dissertação (Mestrado em Antropologia Social). Pontifícia Universidade Católica de São Paulo, São Paulo, 1992.

- Espaço Geográfico Guarani-Mbya: Significado, Constituição e Uso. Tese (Doutorado em Geografia Social). São Paulo: FFLCH - USP, 2001.

LÉVI-STRAUSS, Claude. Introdução: História e Etnologia. In: Antropologia Estrutural. 5 ${ }^{\mathrm{a}}$ ed. Rio de Janeiro: Tempo Brasileiro, 1949 [1996], p. 13 - 41.

Introdução: O feiticeiro e sua magia. In: Antropologia Estrutural. 5a ed. Rio de Janeiro: Tempo Brasileiro, 1949 [1996], p. 193 - 213

LITAIFF, Aldo. As Divinas Palavras: representações étnicas dos Guarani-Mbyá. Dissertação (Mestrado em Antropologia Social). Universidade Federal de Santa Catarina, Florianópolis, 1991.

MELIÁ, Bartolomeu. A Experiência Religiosa Guarani In: MARZAL, Manuel M. et al. O Rosto Índio de Deus. São Paulo: Vozes, 1989, Capítulo V, p. 293 - 348.

MONTEIRO, John Manuel. Negros da terra. Índios e bandeirantes nas origens de São Paulo. São Paulo: Companhia das Letras, 2004. 
. Os Guarani e a história do Brasil meridional: séculos XVI-XVII. In: CARNEIRO DA CUNHA, Manuela. História dos índios no Brasil. São Paulo: Companhia das Letras, Secretaria Municipal de Cultura, Fapesp, 1992.

NIMUENDAJU, Curt. As Lendas da Criação e da Destruição do Mundo como Fundamentos da Religião dos Apapocúva-Guarani. São Paulo: Hucitec, Edusp, 1987.

MONTARDO, Deise Lucy Oliveira. Através do Mbaraka: musica e xamanismo guarani. Tese (Doutorado em Antropologia Social). Universidade de São Paulo - USP, São Paulo, 2002.

OLIVEIRA, Vera Lúcia de. Mba'e Vyky: o que a gente faz. Cotidiano e cosmologia Guarani Mbya. Dissertação (Mestrado em Antropologia Social). Universidade Federal do Rio de Janeiro, Rio de Janeiro, 2002.

PEREIRA, Levi Marques. Parentesco e Organização Social Kaiowá. Dissertação (Mestrado em Antropologia Social). Universidade Estadual de Capinas, Campinas, 1999.

O pentecostalismo kaiowá: uma aproximação aos aspectos sociocosmológicos e históricos. In: Grupo do Fórum de Pesquisa de Missões, Associação Brasileira de Antropologia, 2002, mimeo.

Imagens kaiowá do sistema social e seu entorno. Tese (Doutorado em Antropologia Social). Universidade de São Paulo, USP, São Paulo, 2004.

PISSOLATO, Elizabeth de Paula. A duração da pessoa: mobilidade, parentesco e xamanismo mbya (guarani). Tese (Doutorado). Museu Nacional, Rio de Janeiro, 2006.

RICARDO, Carlos Alberto (ed.). POVOS INDÍGENAS NO BRASIL - 1996-2000. São Paulo: Instituto Socioambiental, 2001.

SAHLINS, Marshall. Ilhas de História. Rio de Janeiro: Jorge Zahar Editor, 1990.

1997. "O 'pessimismo sentimental' e a experiência etnográfica: porque a cultura não é um 'objeto' em via de extinção" (Parte I e II) In Mana - Estudos de Antropologia Social. PPGAS-MN-Universidade Federal do Rio de Janeiro. Vol. 3, no 1 (pp. 41-73) e no 2 (pp. 103150). 
SCHADEN, Egon. Aspectos Fundamentais da Cultura Guarani. 3 ${ }^{\mathrm{a}}$ ed. São Paulo: E.P.U./Edusp, 1974.

A religião guarani e o cristianismo: contribuição ao estudo de um processo histórico de comunicação intercultural. In: Revista de Antropologia. São Paulo: FFLCHUSP, vol. 25, 1982

SEEGER, Anthony; DAMATTA, Roberto A.; VIVEIROS DE CASTRO, Eduardo. A construção da pessoa nas sociedades indígenas brasileiras. In: OLIVEIRA FILHO, J. P. Sociedades indígenas e indigenismo no Brasil. Rio de Janeiro: Ed. Marco Zero e UFRJ, 1987,

SUPLEMENTO ANTROPOLOGICO - Revista Del Centro de Estudios Antropologicos. 1999. Vol. XXXIV no 2 - Homenaje a León Cadogan en el Centenario de su Nacimiento. Assunción - Paraguay: Universidad Catolica.

VIETTA, Kátya. Mbya: Guarani de Verdade. Dissertação (Mestrado em Antropologia Social). Universidade Federal do Rio Grande do Sul, Porto Alegre, 1992.

Os Homens e os deuses: a concepção dual da alma humana e a construção Mbya da pessoa. In Suplemento Antropológico - Revista Del Centro de Estudios Antropologicos. Vol. XXXIV no 2. Assunção, Paraguai: Universidade Católica, 1999.

VIVEIROS DE CASTRO, Eduardo B. Araweté: Os Deuses Canibais. Rio de Janeiro. Jorge Zahar Editor/Anpocs, 1986.

A Inconstância da Alma Selvagem. São Paulo: Cosac \& Naify, 2002.

Vídeos:

- "Jandira". Videofau. FAU - USP, 1992.

- "Teko Arandu - Viver Guarani”, TV Cultura, São Paulo, 1999.

- Video-entrevista de Joaquim Augusto Martim (Kuaray). Centro de Trabalho Indigenista. CTI, São Paulo, s/d. Internet:

- Centro de Trabalho Indigenista - CTI - www.trabalhoindigenista.org

- Instituto Socioambiental - ISA: www.socioambiental.org

- Página do Melatti: www.geocities.com/RainForest/Jungle/6885/index.html

- Cultura Guarani: www.culturaguarani.hpg.ig.com.br/index.html

- Associação Nhandeva: www.nhandeva.org 


\section{Anexo A}

\section{A produção acadêmica sobre os Guarani}

Observando a lista de Teses e Dissertações, produzidas nas instituições de ensino no Brasil, é possível perceber um expressivo aumento do interesse acadêmico sobre os índios Guarani. Nos anos 1990 foram depositadas cerca de dez vezes mais monografias focalizando esse grupo indígena do que nos anos 1980. Já nos anos 2000, o total de Teses e Dissertações é cerca de 50\% maior do que as produzidas nos anos 1990.

Considerando o total das obras acadêmicas as instituições de ensino e pesquisa federais produziram aproximadamente $50 \%$ mais do que as estaduais e particulares, consideradas separadamente. Entre as instituições particulares e as públicas estaduais a diferença foi pequena, cerca de $20 \%$ as primeiras e $30 \%$ as segundas, em relação à produção total do período entre as décadas de 1980 e 2000.

Se considerarmos as instituições de ensino e pesquisa isoladamente, a Universidade de São Paulo foi a que mais produziu monografias tendo os Guarani como foco, seguida pela PUC - RGS e pela Federal do Paraná. Dentre as instituições públicas estaduais, a maior produção do estado de São Paulo. E dentre o total geral de obras acadêmicas, as instituições de ensino ligadas a instituições religiosas têm uma contribuição considerável, com destaque para as Universidades Católicas. 


\section{Lista de obras por data - Teses e Dissertações}

1987

JOSE OTAVIO CATAFESTO DE SOUZA. UMA INTRODUCAO AO SISTEMA TECNICO ECONOMICO GUARANI. 01/12/1987

1v. 548p. Mestrado. UNIVERSIDADE FEDERAL DO RIO GRANDE DO SUL ANTROPOLOGIA SOCIAL

Orientador(es): Nome não Informado.

Biblioteca Depositaria:

YUNES GILBERTO SARKIS. A PARTICIPACAO DO CONTEXTO URBANO NA FORMACAO DAS REDUCOES JESUITICO GUARANIS. 01/09/1987

1v. 167p. Mestrado. UNIVERSIDADE DE SÃO PAULO/SÃO CARLOS ARQUITETURA

Orientador(es): Nome não Informado.

Biblioteca Depositaria:

1988

EDUARDO FLEURY MORTIMER 00687888010. AÇÃO LINGÜÍSTICA DOS TUPINIQUINS E GUARANIS DO ESPÍRITO SANTO. LEVANTAMENTO LINGÜISTÍCO E SOCIOLINGÜÍSTICO DAS COMUNIDADES INDÍGENAS. 01/12/1988

0v. 397p. Mestrado. UNIVERSIDADE FEDERAL DE MINAS GERAIS EDUCAÇÃO

Orientador(es): Nome não Informado.

Biblioteca Depositaria: Biblioteca da Faculdade de Educação da UFMG

MARIA CRISTINA DOS SANTOS. MOVIMENTOS GUARANI DE RESISTENCIA A COLONIZACAO DA BACIA PLATINA 1537-1660.. 01/11/1988

1v. 230p. Mestrado. PONTIFÍCIA UNIVERSIDADE CATÓLICA DO RIO GRANDE DO SUL - HISTÓRIA

Orientador(es): Nome não Informado.

Biblioteca Depositaria

1989

CARLOS ROBERTO ZIBEL COSTA. HABITA€AO GUARANI: TRADI€AO CONSTRUTIVA E MITOLOGIA. 01/08/1989

2v. 1p. Doutorado. UNIVERSIDADE DE SÃO PAULO - ARQUITETURA E URBANISMO

Orientador(es): Nome não Informado.

Biblioteca Depositaria:

FAUSTO PIRES DE CAMPOS. POR UMA TERRA SEM MAL. 01/01/1989 
1v. 210p. Mestrado. UNIVERSIDADE DE SÃO PAULO - CIENCIAS DA COMUNICACAO

Orientador(es): Nome não Informado.

Biblioteca Depositaria:

1990

MARIA CRISTINA SCATAMACCHIA. A TRADICAO POLICRONICA NO LESTE DA MAERICA DO SUL EVIDENCIADA PELA OCUPACAO GUARANI E TUPINAMBA: FONTES ARQUEOLOGICAS E ETNO-HISTORICAS. 01/05/1990

1v. 300p. Doutorado. UNIVERSIDADE DE SÃO PAULO - CIÊNCIA SOCIAL (ANTROPOLOGIA SOCIAL) - ARQUEOLOGIA

Orientador(es): Nome não Informado.

Biblioteca Depositaria:

MARIA EVARISTO WENCESLAU. O INDIO KAYOWA E A COMUNIDADE DOS BRANCOS. 01/11/1990

1v. 215p. Mestrado. UNIVERSIDADE DE SÃO PAULO - HISTÓRIA SOCIAL

Orientador(es): Nome não Informado.

Biblioteca Depositaria:

TEREZINHA DE JESUS MACHADO MAHER. JA QUE E PRECISO FALAR COM OS DOUTORES DE BRASILIA... SUBSIDIOS PARA O PLANEJAMENTO DE UM CURSO DE PORTUGUES ORAL EM CONTEXTO INDIGENA. 01/08/1990

1v. 140p. Mestrado. UNIVERSIDADE ESTADUAL DE CAMPINAS - LINGUISTICA APLICADA - EDUCAÇÃO

Orientador(es): Nome não Informado.

Biblioteca Depositaria:

1991

ALDO LITAIFF. AS DIVINAS PALAVRAS: REPRESENTACOES ETNICAS DOS GUARANI-MBYA.. 01/10/1991

1v. 170p. Mestrado. UNIVERSIDADE FEDERAL DE SANTA CATARINA ANTROPOLOGIA SOCIAL

Orientador(es): ESTHER JEAN LANGDON

ELIANE CRISTINA DECKMANN. O IMAGINARIO DOS SECULOS XVI E XVII - SUAS MANISFESTACOES E ALTERACOES. 01/09/1991

2v. 572p. Mestrado. UNIVERSIDADE DO VALE DO RIO DOS SINOS - HISTÓRIA

Orientador(es): BARTOLOME LLITERAS MELIA

Biblioteca Depositaria

FERNANDA BORDIN TOCCHETTO. "A CULTURA MATERIAL DO GUARANI MISSIONEIRO COMO SIMBOLO DE IDENTIDADE ETNICA". 01/04/1991 
1v. 270p. Mestrado. UNIVERSIDADE FEDERAL DE SANTA CATARINA ANTROPOLOGIA SOCIAL

Orientador(es): ESTHER JEAN LANGDON

Biblioteca Depositaria:

MARIA CRISTINA BOHN MARTINS. OS GUARANIS E A ECONOMIA DE RECIPROCIDADE. 01/09/1991

1v. 386p. Mestrado. UNIVERSIDADE DO VALE DO RIO DOS SINOS - HISTÓRIA

Orientador(es): BARTOLOME LLITERAS MELIA

Biblioteca Depositaria:

Ruben Ferreira Thomaz de Almeida. O Projeto Kaiowá-Ñandeva : uma experiência de etnodesenvolvimento junto aos Guarani-Kaiowá e Guarani-Ñandeva contemporâneos do Mato Grosso do Sul. 1991

1v. 441p. Mestrado. UNIVERSIDADE FEDERAL DO RIO DE JANEIRO ANTROPOLOGIA

Orientador(es):

Biblioteca Depositaria:

1992

ANA CLARA M. DAVALOS MISSLITZ. POLIMORFISMO DA PROTEINA GC EM INDIGENAS BRASILEIROS. 01/05/1992

1v. 96p. Mestrado. UNIVERSIDADE DE SÃO PAULO/ RIBEIRÃO PRETO CIENCIAS BIOLOGICAS (GENETICA)

Orientador(es): AGUINALDO LUIZ SIMOES

KATYA VIETTA. MBYA: GUARANI DE VERDADE. 01/08/1992

1v. 198p. Mestrado. UNIVERSIDADE FEDERAL DO RIO GRANDE DO SUL ANTROPOLOGIA SOCIAL

Orientador(es): PEDRO IGNACIO SCHMITZ

Biblioteca Depositaria:

Maria Inês Martins Ladeira. Espaço Geográfico Guarani-Mbya: significado, constituição e uso. 01/08/2001

1v. 270p. Doutorado. UNIVERSIDADE DE SÃO PAULO - GEOGRAFIA (GEOGRAFIA HUMANA)

Orientador(es): Ariovaldo Umbelino de Oliveira

Biblioteca Depositaria: CAPH - USP

MONICA POLIDORO BELICH. ANALISE DOS ALELOS HLA-A, B, C NAS TRIBOS INDIGENAS KAINGANG E GUARANI POR SEQUENCIAMENTO DE DNA C E FOCALIZACAO ISOELETRICA. 01/08/1992

1v. 146p. Mestrado. UNIVERSIDADE FEDERAL DO PARANÁ - GENÉTICA

Orientador(es): PETZL-ERLER MARIA LUIZA

Biblioteca Depositaria: 
ANTONIO JACO BRAND. O CONFINAMENTO E SEU IMPACTO SOBRE OS PAI/KAIOWA.. 01/12/1993

1v. 276p. Mestrado. PONTIFÍCIA UNIVERSIDADE CATÓLICA DO RIO GRANDE DO SUL - HISTÓRIA

Orientador(es): PAULA CALEFFI GIORGIS

Biblioteca Depositaria:

CAMILA PEREIRA. ESTUDO DE QUATRO POLIMORFISMOS ENZIMATICOS ERITROCITARIOS (ESD, CAII, GLO E PGM1) EM INDIGENAS KAINGANG E GUARANI.. 01/02/1993

1v. 100p. Mestrado. UNIVERSIDADE DE SÃO PAULO/ RIBEIRÃO PRETO CIENCIAS BIOLOGICAS (GENETICA)

Orientador(es): AGUINALDO LUIZ SIMOES

Biblioteca Depositaria

FRANCISCO SILVA NOELLI. SEM TEKOHA NAO HA TEKO - EM BUSCA DE UM MODELO ETNOARQUEOLOGICO DA ALDEIA E DA SUBSISTENCIA E SUA APLICACAO A UMA AREA DE DOMINIO NO DELTA DO RIO JACUI/RS.. 01/05/1993

2v. 490p. Mestrado. PONTIFÍCIA UNIVERSIDADE CATÓLICA DO RIO GRANDE DO SUL - HISTÓRIA

Orientador(es): PAULA CALEFFI GIORGIS

Biblioteca Depositaria:

JOSE LINO MENEGASSI. A MORTE NA VIDA GUARANI.. 01/09/1993

1v. 200p. Mestrado. PONTIFÍCIA UNIVERSIDADE CATÓLICA DE SÃO PAULO CIÊNCIAS DA RELIGIÃO

Orientador(es): BARTOLOMEU MELLIA

Biblioteca Depositaria:

MARIA DA GLORIA PORTO KOK. OS VIVOS E OS MORTOS NO BRASIL COLONIAL DA ANTROPOFAGIA A AGUA DO BATISMO.. 01/04/1993

1v. 218p. Mestrado. UNIVERSIDADE DE SÃO PAULO - HISTÓRIA SOCIAL

Orientador(es): Nome não Informado.

Biblioteca Depositaria:

REJANE DA SILVEIRA SEVERAL. JESUITAS E GUARANIS FACE AOS IMPERIOS COLONIAIS IBERICOS NO RIO DA PRATA COLONIAL.. 01/05/1993

1v. 241p. Mestrado. PONTIFÍCIA UNIVERSIDADE CATÓLICA DO RIO GRANDE DO SUL - HISTÓRIA

Orientador(es): ARNO ALVAREZ KERN

Biblioteca Depositaria 
ARAMITA RIBEIRO TERRA. O SUICIDIO DE JOVENS INDIGENAS KAYOWAS DE DOURADOS M.M. - UMA EXPLICACAO PSICOLOGICA. 01/04/1994

1v. 224p. Mestrado. PONTIFÍCIA UNIVERSIDADE CATÓLICA DE CAMPINAS PSICOLOGIA

Orientador(es): MAURO MARTINS AMATUZZI

Biblioteca Depositaria

CANDIDA GRACIELA CHAMORRO ARGUELLO. KURUSU NE'ENGATU OU PALAVRAS QUE A HISTORIA NAO PODERIA ESQUECER.. 01/01/1994

1v. 184p. Mestrado. UNIVERSIDADE DO VALE DO RIO DOS SINOS - HISTÓRIA

Orientador(es): BARTOLOME LLITERAS MELIA

Biblioteca Depositaria

CARLA GONCALVES ANTUNHA BARBOSA. TRAZIDOS... POR TUPA 9A LUTA PELO TERRITORIO GUARANI EM SAO PAULO. 01/10/1994

1v. 190p. Mestrado. UNIVERSIDADE DE SÃO PAULO - GEOGRAFIA (GEOGRAFIA HUMANA)

Orientador(es): ARIOVALDO UMBELINO DE OLIVEIRA

Biblioteca Depositaria:

MARINA EVARISTO WENCESLAU. O INDIO KAIOWA: SUICIDIO PELO TEKOHA.. $01 / 12 / 1994$

1v. 485p. Doutorado. UNIVERSIDADE DE SÃO PAULO - HISTÓRIA SOCIAL

Orientador(es): JOSE CARLOS SEBE BOM MEIHY

Biblioteca Depositaria:

VANESSA SANTOS SOTOMAIOR. ANALISE DOS ALELOS HLA-DQB1 DE INDIOS KAINGANG E GUARANI ATRAVES DE OLIGONUCLEOTIDEOS-SONDAESOECIFICOS. 01/12/1994

1v. 121p. Mestrado. UNIVERSIDADE FEDERAL DO PARANÁ - GENÉTICA

Orientador(es): PETZL-ERLER MARIA LUIZA

Biblioteca Depositaria:

WALDEMAR FERREIRA NETTO. OS INDIOS E A ALFABETIZACAO:ASPECTOS DE EDUCACAO ESCOLAR ENTRE OS GUARANI DE RIBEIRAO SILVEIRA.. 01/05/1994

1v. 187p. Doutorado. UNIVERSIDADE DE SÃO PAULO - LINGUISTICA

Orientador(es): ERASMO D'ALMEIDA MAGALHAES

Biblioteca Depositaria

1995

BEATRIZ DOS SANTOS LANDA. MULHER GUARANI: ATIVIDADES E CULTURA MATERIAL.. 01/08/1995

1v. 160p. Mestrado. PONTIFÍCIA UNIVERSIDADE CATÓLICA DO RIO GRANDE 
DO SUL - HISTÓRIA

Orientador(es): JOSE JUSTINIANO PROEN BROCHADO

Biblioteca Depositaria:

EDUARDO SANTOS NEUMANN. "GUARANIS MISSIONEIROS EM BUENOS AIRES: 1640-1750.". 01/04/1995

1v. 240p. Mestrado. UNIVERSIDADE FEDERAL DO RIO GRANDE DO SUL HISTÓRIA

Orientador(es): Nome não Informado.

Biblioteca Depositaria:

GISLENE MONTICELLI. VASILHAS DE CERAMICA GUARANI: UM RESGATE DA MEMORIA ENTRE OS MBYA.. 01/08/1995

1v. 200p. Mestrado. PONTIFÍCIA UNIVERSIDADE CATÓLICA DO RIO GRANDE DO SUL - HISTÓRIA

Orientador(es): JOSE JUSTINIANO PROEN BROCHADO

Biblioteca Depositaria

JACKELINE RODRIGUES MENDES. DESCOMPASSOS NA INTERACAO PROFESSOR-ALUNO NA AULA DE MATEMATICA EM CONTEXTO INDIGENA. 01/03/1995

1v. 81p. Mestrado. UNIVERSIDADE ESTADUAL DE CAMPINAS - LINGUISTICA APLICADA

Orientador(es): MARILDA DO COUTO CAVALCANTI

Biblioteca Depositaria:

JOAO JOSE DE FELIX PEREIRA. MORRO DA SAUDADE MIMBY: A ARTE DE FAZER E TOCAR FLAUTA DE BAMBU.. 01/08/1995

1v. 220p. Mestrado. PONTIFÍCIA UNIVERSIDADE CATÓLICA DE SÃO PAULO COMUNICAÇÃO/SEMIÓTICA - EDUCAÇÃO

Orientador(es): JERUSA PIRES FERREIRA

Biblioteca Depositaria

MARILIA GOMES GHIZZI GODOY. TEKO AXY: O MISTICISMO GUARANI MBYA NA ERA DO SOFRIMENTO E DA IMPERFEICAO.. 01/06/1995

1v. 330p. Doutorado. PONTIFÍCIA UNIVERSIDADE CATÓLICA DE SÃO PAULO PSICOLOGIA (PSICOLOGIA SOCIAL)

Orientador(es): ANTONIO DA COSTA CIAMPA

Biblioteca Depositaria:

PROTASIO PAULO LANGER. A ALDEIA NOSSA SENHORA DOS ANJOS: A RESISTENCIA DO GUARANI-MISSIONEIRO AO PROCESSO DE DOMINACAO DO SISTEMA COLONIAL LUSO (1762-1798).. 01/08/1995

1v. 200p. Mestrado. UNIVERSIDADE DO VALE DO RIO DOS SINOS - HISTÓRIA

Orientador(es): IEDA GUTFREIND

Biblioteca Depositaria: 
RICARDO LEHTONEN RODRIGUES SOUZA. Estudos sobre uma nova banda da butirilcolinesterase humana (C4/5) verificada em eletroforese. 01/03/1995

1v. 74p. Mestrado. UNIVERSIDADE FEDERAL DO PARANÁ - GENÉTICA

Orientador(es): ELEIDI AL CHAUTARD-FREIRE-MAIA

Biblioteca Depositaria:

SAMUEL EDMUNDO L. BELLO. EDUCACAO MATEMATICA INDIGENA - UM ESTUDO ETNOMATEMATICO COM OS INDIOS GUARANI-KAIOVA DO MATO GROSSO DO SUL.. 01/08/1995

1v. 149p. Mestrado. UNIVERSIDADE FEDERAL DO PARANÁ - EDUCAÇÃO

Orientador(es): UBIRATAN DAMBROSIO

Biblioteca Depositaria

ZAIRA REJANE SILVA OLIVEIRA. A QUESTAO DA CHEFIA NA SOCIEDADE GUARANI.. 01/05/1995

1v. 312p. Mestrado. UNIVERSIDADE DO VALE DO RIO DOS SINOS - HISTÓRIA

Orientador(es): BARTOLOME LLITERAS MELIA

Biblioteca Depositaria:

1996

André Luis Ramos Soares. Organização Sócio-Política Guarani: Aportes para a Investigação Arqueológica. 01/08/1996

1v. 215p. Mestrado. PONTIFÍCIA UNIVERSIDADE CATÓLICA DO RIO GRANDE DO SUL - HISTORIA

Orientador(es): José Joaquim Justiniano Proenza Brochado

Biblioteca Depositaria: Biblioteca Central Irmão José Otão - PUCRS

ANIBAL COSTA DE SOUSA. O ÍNDIO COMO IMAGEM; REPRESENTAÇÕES DO ÍNDIO NAS MISSÕES GESUÍTICAS DO PARAGUAY (SÉCULOS XVII-XVIII).. 01/04/1996

1v. 216p. Mestrado. UNIVERSIDADE FEDERAL DO PARANÁ - HISTORIA

Orientador(es): RONALD JOSÉ RAMINELLI

Biblioteca Depositaria: BIBLIOTECA CENTRAL - UFPR

Cândida Graciela Chamorro Arguelo. PAPA TAPIA RETE MARANGATU (que nossos corpos tenham sempre algo bom para contar) Experiência religiosa guarani como ato de dizerse. 01/11/1996

11v. 292p. Doutorado. ESCOLA SUPERIOR DE TEOLOGIA - TEOLOGIA

Orientador(es): Wanda Deifelt

Biblioteca Depositaria: Escola Superior de teologia

Gilson Rodolfo Martins. "Arqueologia do Planalto Maracaju-Campo Grande: O Estudo do Sítio Maracaju-1 através da Análise Quantitativa de sua Indústria Lítica". 01/10/1996

1v. 281p. Doutorado. UNIVERSIDADE DE SÃO PAULO - ARQUEOLOGIA 
Orientador(es): José Luiz de Morais

Biblioteca Depositaria: MAE-USP

Gisele Teresinha Maciel Damiani. O Guarani: Uma Experiência de Guerra. 01/08/1996

1v. 131p. Mestrado. PONTIFÍCIA UNIVERSIDADE CATÓLICA DO RIO GRANDE

DO SUL - HISTORIA

Orientador(es): Maria Cristina dos Santos

Biblioteca Depositaria: Biblioteca Central Irmão José Otão - PUCRS

Marci Fileti Martins. Incorporação Nominal em Guarani MBYA. 01/09/1996

1v. 130p. Mestrado. UNIVERSIDADE FEDERAL DE SANTA CATARINA LETRAS (LINGUISTICA)

Orientador(es): Lucy Seki

Biblioteca Depositaria: Biblioteca Universitária - UFSC

Maria Inês Coutinho. A Resistência pelo Estético: Imaginária Guarani nas Missões Jesuíticas do Brasil. 01/01/1996

1v. 253p. Mestrado. PONTIFÍCIA UNIVERSIDADE CATÓLICA DO RIO GRANDE DO SUL - HISTORIA

Orientador(es): Maria Cristina dos Santos

Biblioteca Depositaria: Biblioteca Central Irmão José Otão - PUCRS

Paulo Rogério de Melo de Oliveira. O Naturalista e o Selvagem; a visão de Saint-Hilaire dobre os índios guaranis no Rio Grande do Sul.. 01/08/1996

1v. 134p. Mestrado. UNIVERSIDADE FEDERAL DE SANTA CATARINA HISTORIA

Orientador(es): Joana Maria Pedro

Biblioteca Depositaria: Biblioteca Central da UFSC

Sarah Iurkiv Gomes Tibes Ribeiro. Sob o Domínio da Tradição: Um Estudo Sobre as Manifesatções do Poder nas Lideranças Políticas Guarani 1534-1579. 01/04/1996

1v. 157p. Mestrado. PONTIFÍCIA UNIVERSIDADE CATÓLICA DO RIO GRANDE DO SUL - HISTORIA

Orientador(es): Maria Cristina dos Santos

Biblioteca Depositaria: Biblioteca Irmão José Otão - PUCRS

1997

Artur Henrique Franco Barcelos. Espaço e Arqueologia nas Missões Jesuíticas: o Caso da Redução de São Josão Batista. 01/08/1997

1v. 395p. Mestrado. PONTIFÍCIA UNIVERSIDADE CATÓLICA DO RIO GRANDE DO SUL - HISTORIA

Orientador(es): Arno Alvarez Kern

Biblioteca Depositaria: Biblioteca Central da PUCRS 
DORA SHELLARD CORREA. "PAISAGENS SOBREPOSTAS. Índios, posseiros e fazendeiros nas Matas de Itapeva (1723-1930)". 01/05/1997

1v. 349p. Doutorado. UNIVERSIDADE DE SÃO PAULO - HISTÓRIA ECONÔMICA - HISTÓRIA

Orientador(es): MARIA THEREZA SCHORER PETRONE

Biblioteca Depositaria: CAPH

ÉRICO BRASIL FERREIRA COSTA. Assentamento dos grupos Tupi-Guarani e Vieira no sudeste do Rio Grande do Sul: Santa Vitória do Palmar, Rio Grande e Camaquã. 01/08/1997

1v. 200p. Mestrado. UNIVERSIDADE DO VALE DO RIO DOS SINOS - HISTORIA

Orientador(es): Pedro Augusto Mentz Ribeiro; Pedro Ignacio Schmitz

Biblioteca Depositaria: Biblioteca Central da UNISINOS

FÁBIO MURA. Habitações Kaiowá : formas, propriedades, técnicas e organização social.. 01/05/1997

Mestrado. UNIVERSIDADE FEDERAL DO RIO DE JANEIRO - ANTROPOLOGIA

Orientador(es):

Biblioteca Depositaria:

FÁBIO RUEDA FAUCZ. Variabilidade dos genes TAP1, TAP2, LMP2 e LMP7 de duas populações indígenas paranaenses: Kainganf e guarani.. 01/05/1997

1v. 98p. Mestrado. UNIVERSIDADE FEDERAL DO PARANÁ - GENETICA

Orientador(es): MARIA LUIZA PETZL-ERLER

Biblioteca Depositaria: Biblioteca Central da UFPRr

Ivori José Garlet. Mobilidade Mbyá: História e Significação. 01/04/1997

1v. 217p. Mestrado. PONTIFÍCIA UNIVERSIDADE CATÓLICA DO RIO GRANDE DO SUL - HISTORIA

Orientador(es): Maria Cristina dos Santos

Biblioteca Depositaria: Biblioteca Central da PUCRS

LUCIO PAIVA FLORES. Kaiuá até a Morte - Um estudo pastoral das transformações sofridas pelo índio Kaiuá.. 01/09/1997

1v. 112p. Mestrado. UNIVERSIDADE METODISTA DE SÃO PAULO - CIENCIAS

DA RELIGIAO

Orientador(es): Ronaldo Sathler Rosa

Biblioteca Depositaria: do Curso e da UMESP

MARIA DAS GRAÇAS SERAFIM. Hábitos alimentares e nível de hemoglobina em crianças indígenas guarani, menores de 5 anos, dos estados de São Paulo e Rio de Janeiro. 01/12/1997

1v. 84p. Mestrado. UNIVERSIDADE FEDERAL DE SÃO PAULO - MEDICINA (PEDIATRIA)

Orientador(es): FABIO ANCONA LOPEZ

Biblioteca Depositaria: Biblac 
1998

ALBERTO MOBY RIBEIRO DA SILVA. A noite dos Kygua Vera. A mulher e a reconstrução da identidade nacional paraguaia (1869-1904).. 01/05/1998

1v. 298p. Doutorado. UNIVERSIDADE FEDERAL FLUMINENSE - HISTÓRIA

Orientador(es): ISMENIA DE LIMA MARTINS

Biblioteca Depositaria: Biblioteca Central do Gragoatá - UFF

Antonio Jaco Brand. O Impacto da Perda da Terra sobre a Tradição Kaiowá/Guarani: Os Difíceis Caminhos da Palavra. 01/04/1998

1v. 382p. Doutorado. PONTIFÍCIA UNIVERSIDADE CATÓLICA DO RIO GRANDE DO SUL - HISTÓRIA

Orientador(es): Earle Diniz Macarthy Moreira

Biblioteca Depositaria: Biblioteca Central da PUCRS

CERES KARAM BRUM. LENDÁRIO MISSIONEIRO: PEDAGOGIA JESUÍTICA PARA A INTEGRAÇÃO COLONIAL NOS SETE POVOS DAS MISSÕES. 01/12/1998

4v. 192p. Mestrado. UNIVERSIDADE FEDERAL DE SANTA MARIA - EDUCAÇÃO

Orientador(es): Jorge Luiz da Cunha

Biblioteca Depositaria: CENTRAL/UFSM E SETORIAL/CE

Cleusa SChafhauser. Diversidade alélica e haplotípica de genes HLA não-clássicos e desequilibrio de ligação destes com outros onze genes do MHC, em populações indígenas e caucasóides do Paraná.. 01/07/1998

1v. 100p. Mestrado. UNIVERSIDADE FEDERAL DO PARANÁ - GENÉTICA

Orientador(es): Maria Luiza Petzl-Erler

Biblioteca Depositaria: Biblioteca Central da UFPR

JULIO CESAR DE MORAES. Fertilidade do solo como parâmetro para a avaliação da sustentabilidade agro-ambiental em áreas de cultivo tradicional das comunidade indígenas Guarani na região da Serra do Mar (SP, RJ). 01/04/1998

1v. 165p. Mestrado. UNIVERSIDADE EST.PAULISTA JÚLIO DE MESQUITA FILHO/BOTUCATU - AGRONOMIA (ENERGIA NA AGRICULTURA)

Orientador(es): Ademercio Antonio Paccola

Biblioteca Depositaria: Prof. Paulo de Carvalho Mattos

LUCIO TADEU MOTA. O AÇO, A CRUZ E A TERRA: ÍNDIOS E BRANCOS NO PARANÁ PROVINCIAL (1853-1889). 01/03/1998

1v. 531p. Doutorado. UNIVERSIDADE EST.PAULISTA JÚLIO DE MESQUITA FILHO/ASSIS - HISTÓRIA

Orientador(es): PAULO ALVES

Biblioteca Depositaria: UNESP/FCL/ASSIS

Marta Rosa Amoroso. "Catequese e evasão. Etnografia do aldeamento indígena de São Pedro de Alcântara. Paraná (1855-1895)".. 01/12/1998

1v. 256p. Doutorado. UNIVERSIDADE DE SÃO PAULO - CIÊNCIA SOCIAL 


\section{(ANTROPOLOGIA SOCIAL)}

Orientador(es): Maria Manuela Ligeti Carneiro da Cunha

Biblioteca Depositaria: FFLCH

PAULO HUMBERTO PORTO BORGES. YMÃ, ANO MIL E QUINHENTOS ESCOLARIZAÇÃO E HISTORICIDADE GUARANI MBY NA ALDEIA DE SAPUKAI. 01/07/1998

1v. 140p. Mestrado. UNIVERSIDADE ESTADUAL DE CAMPINAS - EDUCAÇÃO

Orientador(es): ERNESTA ZAMBONI

Biblioteca Depositaria: BIBLIOTECA CENTRAL DA UNICAMP

Thaís Luiza Colaço. O direito Guarani pré-colonial e as missões jesuíticas: a questão da incapacidade indigena e da tutela religiosa. 01/08/1998

1v. 380p. Doutorado. UNIVERSIDADE FEDERAL DE SANTA CATARINA DIREITO

Orientador(es): Antônio Carlos Wolkmer

Biblioteca Depositaria: BU

1999

CERES KARAM BRUM. INTEGRAÇÃO: UMA CATEGORIA PARA ESTUDAR A ATUAÇÃO DO PADRE ANTÔNIO SEPP NAS MISSÕES. 01/01/1999

3v. 87p. Mestrado. UNIVERSIDADE FEDERAL DE SANTA MARIA INTEGRAÇÃO LATINO - AMERICANA

Orientador(es): JORGE LUIZ DA CUNHA

Biblioteca Depositaria: UFSM - MILA - PRPGP

Eliane Cristina Deckmann Fleck. Sentir, Adoecer e Morrer-Sensibilidade e Devoção no Discurso Missionário Jesuítico do Século XVII.. 01/11/1999

1v. 353p. Doutorado. PONTIFÍCIA UNIVERSIDADE CATÓLICA DO RIO GRANDE

DO SUL - HISTÓRIA

Orientador(es): Maria Cristina dos Santos

Biblioteca Depositaria: Irmão José Otão/PUCRS

José Carlos Damasceno. A não concordância em gênero no português falado pelos guaranis Nhandeva do estado do Espírito Santo. 01/12/1999

1v. 192p. Mestrado. UNIVERSIDADE EST.PAULISTA JÚLIO DE MESQUITA FILHO/ARARAQUARA - LETRAS (LINGÜÍSTICA E LÍNGUA PORTUGUESA)

Orientador(es): ERASMO D'ALMEIDA MAGALHÃES

Biblioteca Depositaria: Faculdade de Ciências e Letras

José Exequiel Basini Rodriguez. Mbyá Guaraní, Mito Praxis, Estratégias. 01/03/1999

1v. 240p. Mestrado. UNIVERSIDADE FEDERAL DO RIO GRANDE DO SUL ANTROPOLOGIA SOCIAL

Orientador(es): Oscar Alfredo Aguero

Biblioteca Depositaria: BSCHS 
Levi Marques Pereira. Parentesco e organização social Kaiowá. 01/10/1999

1v. 246p. Mestrado. UNIVERSIDADE ESTADUAL DE CAMPINAS ANTROPOLOGIA SOCIAL

Orientador(es): Márcio Ferreira da Silva

Luiz Carlos Borges. FALA INSTITUINTE DO DISCURSO MÍTICO GUARANI MBYÁ.. 01/03/1999

1v. 366p. Doutorado. UNIVERSIDADE ESTADUAL DE CAMPINAS LINGÜÍSTICA

Orientador(es): Eni de Lourdes Pulcinelli Orlandi

Biblioteca Depositaria: Biblioteca Central da Unicamp

Margareth Araújo e Silva Costa. Comunidade Guarani: em busca de subsídios para uma educação socioambiental.. 01/12/1999

1v. 164p. Mestrado. UNIVERSIDADE FEDERAL DO ESPÍRITO SANTO EDUCAÇÃO

Orientador(es): Jaime Roy Doxsey

Biblioteca Depositaria: Biblioteca do INEP

Mari Noeli Kiel Iapechino. O Discurso da Criação na Cultura Guarani e o Processo de Constituição da Brasilidade. 01/09/1999

1v. 152p. Mestrado. PONTIFÍCIA UNIVERSIDADE CATÓLICA DE SÃO PAULO -

LÍNGUA PORTUGUESA - LETRAS

Orientador(es): JARBAS VARGAS NASCIMENTO

Biblioteca Depositaria: PUC/SP

Maria Cristina Bohn Martins. A Festa Guarani das Reduções: perdas, permanências e recriação. 01/11/1999

1v. 304p. Doutorado. PONTIFÍCIA UNIVERSIDADE CATÓLICA DO RIO GRANDE

DO SUL - HISTÓRIA

Orientador(es): Maria Cristina dos Santos

Biblioteca Depositaria: Irmâo José Otão/PUCRS

MARIA ROSA DE MIRANDA COUTINHO. NOSSO MODO DE SER REPRESENTAÇÕES SOBRE SAÚDE E DOENÇA ENTRE OS GUARANÍ-NHANDEVA. $01 / 06 / 1999$

1v. 151p. Mestrado. UNIVERSIDADE FEDERAL DE SÃO CARLOS - CIÊNCIAS SOCIAIS - ANTROPOLOGIA

Orientador(es): MARINA DENISE CARDOSO

Biblioteca Depositaria: BIBLIOTECA COMUNITÁRIA DA UFSCar

Andrey Moreira Cardoso. "Prevalência de Doenças Crônico-Regenerativas na População Guarani-Mbyá do Estado do Rio de Janeiro". 01/09/2000 
1v. 132p. Mestrado. FUNDAÇÃO OSWALDO CRUZ - SAÚDE PÚBLICA

Orientador(es): Inês Echenique Mattos; Rosalina Jorge Koifman

Biblioteca Depositaria: Biblioteca Lincoln de Freitas Filho

Angelica Beate Winter Boldt. Polimorfismo Gênico da Lectina Ligante de Manose em Populações Humanas.. 01/12/2000

1v. 100p. Mestrado. UNIVERSIDADE FEDERAL DO PARANÁ - GENÉTICA

Orientador(es): Maria Luiza Petzl-Erler

Biblioteca Depositaria: Biblioteca Central da Universidade Federal do Paraná

Cássia Ferri. Gênese de um Currículo Multicultural: Tramas de Uma Experiência em Construção no Contexto da Educação Escolar Indígena.. 01/03/2000

1v. 234p. Doutorado. PONTIFÍCIA UNIVERSIDADE CATÓLICA DE SÃO PAULO EDUCAÇÃO (CURRÍCULO)

Orientador(es): MERE ABRAMOWICZ

Biblioteca Depositaria: Pontifícia Universidade Católica de São Paulo

Christian Macagnan Probst. Diversidade alélica e haplotípica dos genes HLA de classe II em populações paranaenses.. 01/12/2000

1v. 104p. Mestrado. UNIVERSIDADE FEDERAL DO PARANÁ - GENÉTICA

Orientador(es): Maria Luiza Petzl-Erler

Biblioteca Depositaria: Biblioteca Central da Universidade Federal do Paraná

Claudia de Oliveira Uessler. Arte Cerâmica nos Povoados Missioneiros: Antigas e Novas Tecnologias. 01/08/2000

1v. 349p. Mestrado. PONTIFÍCIA UNIVERSIDADE CATÓLICA DO RIO GRANDE

DO SUL - HISTÓRIA

Orientador(es): Arno Alvarez Kern

Biblioteca Depositaria: Biblioteca Central Irmão José Otão - PUCRS

ELENO OGLIARI. MISSÕES JESUÍTICO-GUARANIS: PATRIMÔNIO E MEMÓRIA. $01 / 05 / 2000$

2v. 130p. Mestrado. UNIVERSIDADE FEDERAL DE SANTA MARIA INTEGRAÇÃO LATINO - AMERICANA - HISTORIA

Orientador(es): JÚLIO RICARDO QUEVEDO DOS SANTOS

Biblioteca Depositaria: MELA, PRPGP, BIBLOTECA CENTRAL DA UFSM

Gloria Margarita Alcaraz López. "A Fecundidade entre os Guarani: Um Legado de Kunhankarai". 01/12/2000

1v. 212p. Doutorado. FUNDAÇÃO OSWALDO CRUZ - SAÚDE PÚBLICA

Orientador(es): Humberto Ramirez; Ulisses Eugênio Cavalcanti Confalonieri

Biblioteca Depositaria: Biblioteca Lincoln de Freitas Filho

José Roberto de Andrade. Alma, valor, pinga e enunciação: abordagem semiótica do discurso guarani. 01/03/2000

2v. 527p. Mestrado. UNIVERSIDADE DE SÃO PAULO - LINGÜÍSTICA 
Orientador(es): Waldemar Ferreira Netto

Biblioteca Depositaria: Biblioteca de Letras/FFLCH/USP

LEONEL PIOVEZANA. Educação e cultura na terra indígena Xapecó. 01/01/2000

1v. 240p. Mestrado. UNIVERSIDADE DE SANTA CRUZ DO SUL DESENVOLVIMENTO REGIONAL - EDUCAÇÃO

Orientador(es): INÁCIO HELFER

Biblioteca Depositaria: Central

LUIS ALBERTO RODRIGUES DELFIN. Diversidade do cromossomo Y em populações amerindias, negróides, caucasóides e asiáticas. 01/05/2000

1v. 127p. Doutorado. UNIVERSIDADE DE SÃO PAULO/ RIBEIRÃO PRETO CIÊNCIAS BIOLÓGICAS (GENÉTICA)

Orientador(es): MARCO ANTONIO ZAGO

Biblioteca Depositaria: PCARP-USP

MARIA DA GRAÇA MELLO MAGNONI. IMAGINÁRIO ARARIBÁ: UMA PRÁTICA PEDAGÓGICA A SERVIÇO DA RECONSTRUÇÃO DOS VALORES.. 01/10/2000

1v. 180p. Doutorado. UNIVERSIDADE EST.PAULISTA JÚLIO DE MESQUITA FILHO/MARILIA - EDUCAÇÃO

Orientador(es): MAURO CHEROBIM

Biblioteca Depositaria: UNESP/MARÍLIA

Maria Elida Farias Gluchy. Retrospectiva Y Actualización de La Cuestion Guaraní En El Área Deltáica Del Río Negro (Uruguay). 01/08/2000

1v. 167p. Mestrado. PONTIFÍCIA UNIVERSIDADE CATÓLICA DO RIO GRANDE DO SUL - HISTÓRIA

Orientador(es): Klaus Peter Kristian Hilbert

Biblioteca Depositaria: Biblioteca Central Irmão José Otão / PUCRS

Maristela Vilas Boas Fratucci. ALGUNS ASPECTOS DAS CONDIÇÕES DE SAÚDE BUCAL DE UMA POPULAÇÃO INDÍGENA GUARANI MBUÁ NO MUNICÍPIO DE SÃO PAULO. 01/09/2000

1v. 112p. Mestrado. UNIVERSIDADE DE SÃO PAULO - SAÚDE PÚBLICA

Orientador(es): Roberto Augusto Castellanos Fernandez

Biblioteca Depositaria: FSP

2001

Adriana Perez Felipim. O SISTEMA AGRÍCOLA MBYÁ E SEUS CULTIVARES DE MILHO: UM ESTUDO DE CASO NA ALDEIA GUARANI DA ILHA DO CARDOSO, MUNICÍPIO DE CANANÉIA, SP. 01/12/2001

1v. 174p. Mestrado. UNIV.DE SÃO PAULO/ESCOLA SUP. DE AGRICULTURA

LUIZ DE QUEIROZ - RECURSOS FLORESTAIS

Orientador(es): Oriowaldo Queda

Biblioteca Depositaria: Biblioteca Central e IPEF 
Ana Maria Campos Marques. A medicação assistida e os índices de cura e abandono de tratamento na população indígena Guarani-Caiuá no municipio de Dourados, MS. 01/11/2001

1v. 89p. Mestrado. FUNDAÇÃO UNIVERSIDADE FEDERAL DE MATO GROSSO DO SUL - SAÚDE COLETIVA

Orientador(es): Rivaldo Venâncio da Cunha

Biblioteca Depositaria: UFMS

Andréia Aparecida Ferreira Lopes. CORPO E SAÚDE ENTRE OS GUARANI. 01/03/2001

1v. 233p. Mestrado. UNIVERSIDADE ESTADUAL DE CAMPINAS ANTROPOLOGIA SOCIAL

Orientador(es): José Luiz dos Santos

Biblioteca Depositaria: Instituto de Filosofia e Ciências Humanas - Unicamp

ANTONIO JOSÉ FILHO. A LÍNGUA DOS KAIOWA/GUARANI: INTERFERÊNCIAS, EMPRÉSTIMOS LINGÜÍSTICOS E XENISMOS. 01/08/2001

1v. 1p. Mestrado. FUNDAÇÃO UNIVERSIDADE FEDERAL DE MATO GROSSO DO SUL - LETRAS

Orientador(es): Dercir Pedro de Oliveira

Biblioteca Depositaria: BIBLIOTECA "DOM AQUINO CORREA"

CELESTE CICCARONE. DRAMA E SENSIBILIDADE: MIGRAÇÃO, XAMANISMO E MULHERES MBYA GUARANI.. 01/10/2001

1v. 296p. Doutorado. PONTIFÍCIA UNIVERSIDADE CATÓLICA DE SÃO PAULO CIÊNCIAS SOCIAIS

Orientador(es): CARMEN SYLVIA ALVARENGA JUNQUEIRA

Biblioteca Depositaria: Bibliotéca Central da PUCSP

Clovis Antonio Brighenti. Integração e Desistegração: Análise do Tratamento Dispensado pelos Estados Brasileiro e Argentino ao Povo Guarani de Santa Catarina e da Província de Misiones.. 01/05/2001

1v. 257p. Mestrado. UNIVERSIDADE DE SÃO PAULO - INTEGRAÇÃO DA AMÉRICA LATINA - GEOGRAFIA

Orientador(es): Antônio Carlos de Moraes

Biblioteca Depositaria: Biblioteca Central da FFLCH / USP

Ezeula Lima de Quadros. A defesa do modo de ser Guarani - o caso de Caaró e Pirapó, em 1628.. 01/12/2001

1v. 168p. Mestrado. UNIVERSIDADE DO VALE DO RIO DOS SINOS - HISTÓRIA

Orientador(es): BEATRIZ VASCONCELOS FRANZEN

Biblioteca Depositaria: Biblioteca Central da UNISINOS

Flávia Cristina de Melo. Aata Tape Rupy, seguindo pela estrada: uma investigação dos deslocamentos territoriais de famílias Mbyá - Guarani do Sul do Brasil. 01/02/2001

1v. 137p. Mestrado. UNIVERSIDADE FEDERAL DE SANTA CATARINA ANTROPOLOGIA SOCIAL 
Orientador(es): Esther Jean Langdon

Biblioteca Depositaria: UFSC

FRANCISCO FAJARDO. ASPECTOS DA OCUPAÇÃO PRÉ-COLONIAL PLATINA: CABECEIRA DO RAIMUNDO.. 01/11/2001

3v. 85p. Mestrado. UNIVERSIDADE FEDERAL DE SANTA MARIA INTEGRAÇÃO LATINO - AMERICANA - ARQUEOLOGIA

Orientador(es): SAUL EDUARDO SEIGUER MILDER

Biblioteca Depositaria: BIBLIOTECA CENTRAL DA UFSM - BIBLIOTECA DO MILA

GILDA MARIA SALES BARBOSA. Aspectos epidemiológicos descritivos da Leishmaniose tegumentar americana em duas aldeias indígenas Guarani em Paraty, Litoral Sul Fluminense.. $01 / 01 / 2001$

1v. 111p. Doutorado. UNIVERSIDADE FEDERAL RURAL DO RIO DE JANEIRO CIÊNCIAS VETERINÁRIAS

Orientador(es): Adivaldo Henrique da Fonseca; Carlos Luiz Massard; MAURO CELIO DE ALMEIDA MARZOCHI

Biblioteca Depositaria: Biblioteca Central da UFRRJ

Ilda Scanagata Pieruccini. A educação escolar indígena nos aldeamentos Guarani do Estado do Paraná, Brasil.. 01/12/2001

1v. 153p. Mestrado. UNIVERSIDADE FEDERAL DE UBERLÂNDIA - EDUCAÇÃO

Orientador(es): SELVA GUIMARÃES FONSECA

Biblioteca Depositaria: UFU

JAQUELINE BATTILANA. Polimorfismos para as inserções Alu, grupos sangüíneos e sistemas protéicos em populações ameríndias. 01/02/2001

1v. 74p. Mestrado. UNIVERSIDADE FEDERAL DO RIO GRANDE DO SUL GENÉTICA E BIOLOGIA MOLECULAR

Orientador(es): FRANCISCO MAURO SALZANO; SANDRO LUIS BONATTO

Biblioteca Depositaria: Biblioteca Setorial do Instituto de Biociências

LIGIA TEREZINHA LOPES SIMIONIAN. Terra de posseiros: um estudo das politicas sobre terras indígenas. 01/02/2001

1v. 209p. Mestrado. UNIVERSIDADE FEDERAL DO RIO DE JANEIRO ANTROPOLOGIA SOCIAL

Orientador(es):

Biblioteca Depositaria:

Luciane Ouriques Ferreira. Mba'e Achy: a concepção cosmológica da doença entre os MbyáGuarani num contexto de relações interétnicas - RS.. 01/02/2001

1v. 159p. Mestrado. UNIVERSIDADE FEDERAL DO RIO GRANDE DO SUL ANTROPOLOGIA SOCIAL

Orientador(es): Oscar Alfredo Aguero

Biblioteca Depositaria: BSCSH 
Lupe Furtado. Variabilidade da Butirilcolinesterase em Índios Guarani do Mato Grosso do Sul.. 01/02/2001

2v. 123p. Mestrado. UNIVERSIDADE FEDERAL DO PARANÁ - GENÉTICA

Orientador(es): Eleidi Alice Chautard Freire Maia

Biblioteca Depositaria: Biblioteca da Universidade Federal do Paraná

MARIANA PALADINO. "Educação Escolar Indígena no Brasil Contemporâneo : Entre a 'revitalização cultural' e a desintegração do modo de ser tradicional". 01/01/2001

1v. 130p. Mestrado. UNIVERSIDADE FEDERAL DO RIO DE JANEIRO ANTROPOLOGIA SOCIAL

Orientador(es): ANTONIO CARLOS DE SOUZA LIMA

Biblioteca Depositaria: Biblioteca Francisca Keller

Marivaldo Aparecido de Carvalho. 'Passos que não deixam marcas na terra. Os M’byá Guarani e a imprescindível leveza do ser'. 01/04/2001

1v. 220p. Mestrado. UNIVERSIDADE EST.PAULISTA JÚLIO DE MESQUITA FILHO/ARARAQUARA - SOCIOLOGIA

Orientador(es): SILVIA MARIA SCHMUZIGER DE CARVALHO

Biblioteca Depositaria: UNESP/FCLAr

Odécio Tem Caten. Forma(s) de Governo nas Reduções Guaranis. 01/02/2001

1v. 152p. Mestrado. UNIVERSIDADE FEDERAL DE SANTA CATARINA DIREITO

Orientador(es): Antônio Carlos Wolkmer

Biblioteca Depositaria: BU

PROTASIO PAULO LANGER. OS GUARANI-MISSIONEIROS E O COLONIALISMO LUSO NO BRASIL MERIDIONAL: PROJETOS CIVILIZATÓRIOS E FACES DA IDENTIDADE ÉTNICA (1750-1798). 01/12/2001

1v. 328p. Doutorado. UNIVERSIDADE EST.PAULISTA JÚLIO DE MESQUITA FILHO/ASSIS - HISTÓRIA

Orientador(es): IVAN ESPERANÇA ROCHA

Biblioteca Depositaria: FCL - UNESP/ASSIS

Renata Lourenço Girotto. Por uma nova textura histórica: o movimento de professores indígenas Guarani / Kaiová em Mato Grosso do Sul - 1988 a 2000.. 01/08/2001

1v. 143p. Mestrado. FUNDAÇÃO UNIVERSIDADE FEDERAL DE MATO GROSSO DO SUL - HISTÓRIA

Orientador(es): Nilce Aparecida da Silva Freitas Fedatto

Biblioteca Depositaria: Biblioteca da UFMS, Campus de Dourados / Biblioteca Nacional

Robson Antonio Rodrigues. "Cenários de ocupação. Guarani na calha do alto Paraná: um estudo etnoarqueológico". 01/12/2001

1v. 169p. Mestrado. UNIVERSIDADE DE SÃO PAULO - ARQUEOLOGIA

Orientador(es): Marisa Coutinho Afonso 
Biblioteca Depositaria: Faculdade de Filosofia, Letras e Ciências Humanas

Silvia Maria Ferreira Guimarães. Os Guarani-Mbyá e a Superação da Condição Humana. $01 / 04 / 2001$

1v. 151p. Mestrado. UNIVERSIDADE DE BRASÍLIA - ANTROPOLOGIA

Orientador(es): Alcida Rita Ramos

Biblioteca Depositaria: Biblioteca Central da UnB

VALÉRIA FARIA CARDOSO. UM ESTUDO DAS CATEGORIAS SINTAGMÁTICAS DA LIINGUA KAIOWÁ/GUARANI. 01/08/2001

1v. 104p. Mestrado. FUNDAÇÃO UNIVERSIDADE FEDERAL DE MATO GROSSO DO SUL - LETRAS

Orientador(es): Dercir Pedro de Oliveira

Biblioteca Depositaria: BIBLIOTECA"DOM AQUINO CORREA"

\section{2}

Adília Maria Pereira Wiebbelling. Estudo etnoepidemiológico sobre as parasitoses intestinais em índios Mbyá-Guarani da Aldeia do Cantagalo, município de Viamão / RS. 01/12/2002

1v. 130p. Mestrado. UNIVERSIDADE LUTERANA DO BRASIL - SAÚDE COLETIVA

Orientador(es): Elaine da Silveira

Biblioteca Depositaria: Universidade Luterana do Brasil

AGDA REGINA YATSUDA IKUTA. PRÁTICAS FITOTÉCNICAS DE UMA COMUNIDADE INDÍGENA MBYÁ GUARANI, VARZINHA, RIO GRANDE DO SUL: DA ROÇA AO ARTESANATO.. 01/09/2002

1v. 307p. Doutorado. UNIVERSIDADE FEDERAL DO RIO GRANDE DO SUL AGRONOMIA (FITOTECNIA)

Orientador(es): INGRID BERGMAN INCHAUSTI DE BARROS

Biblioteca Depositaria: FACULDADE DE AGRONOMIA / UFRGS

Ana Maria do Perpetuo Socorro dos Santos. O Forte do Iguatemi: Atalaia do Império Colonial e Trincheira da Memória dos Índios Kaiowá da Paraguassu. 01/03/2002

1v. 159p. Mestrado. UNIVERSIDADE ESTADUAL DE CAMPINAS - HISTÓRIA

Orientador(es): Hector Herman Bruit

Biblioteca Depositaria: Biblioteca do IFCH

Ana Paula Simão. Do caco ao fragmento: análise da coleção cerâmicaG uarani do sítio arqueológico Lagoa Xambrê - Altônia/PR. 01/10/2002

1v. 170p. Mestrado. UNIVERSIDADE ESTADUAL DE MARINGÁ - HISTÓRIA

Orientador(es): LUCIO TADEU MOTA

Biblioteca Depositaria: Universidade Estadual de Maringá 
Andréa Maria Duarte Severo. Missões Jesuítico-Guaranis: tempo, espaço e representações. $01 / 08 / 2002$

1v. 230p. Mestrado. PONTIFÍCIA UNIVERSIDADE CATÓLICA DO RIO GRANDE DO SUL - HISTÓRIA

Orientador(es): Arno Alvarez Kern

Biblioteca Depositaria: Biblioteca Irmão José Otão/PUCRS

Angela Maria Lima Santos. A contribuição da arte indígena na construção do saber de enfermagem: um estudo do significado da pintura corporal no ritual de cura dos Guarani de São Paulo. 01/10/2002

1v. 124p. Mestrado. UNIVERSIDADE PRESBITERIANA MACKENZIE EDUCAÇÃO, ARTE E HISTÓRIA DA CULTURA

Orientador(es): Norberto Stori

Biblioteca Depositaria: Biblioteca George Alexander

Carlos Alberto Ungaretti Dias. A escolha de Tibiriça: a sujeição pela fé. 01/06/2002

1v. 247p. Doutorado. UNIVERSIDADE DE SÃO PAULO - HISTÓRIA SOCIAL

Orientador(es): ULYSSES TELLES GUARIBA NETTO

Biblioteca Depositaria: CAPH / SBD

Clarissa Sanfelice Rahmeier. A cerâmica como índice do complexo cultural missioneiro e suas possibilidades ressignificadoras do presente ibero-americano. 01/08/2002

1v. 144p. Mestrado. PONTIFÍCIA UNIVERSIDADE CATÓLICA DO RIO GRANDE DO SUL - HISTÓRIA

Orientador(es): Arno Alvarez Kern

Biblioteca Depositaria: Biblioteca Irmão José Otão/PUCRS

CLAUDETE BOFF. A imaginária guarani: o acervo do museu das missões.. 01/08/2002

1v. 183p. Mestrado. UNIVERSIDADE DO VALE DO RIO DOS SINOS - HISTÓRIA

Orientador(es): MARIA CRISTINA BOHN MARTINS

Biblioteca Depositaria: Biblioteca Central da UNISINOS

Cleide Aparecida Queiroz Sobral. "Prevalência de anticorpos anti-toxoplasma gondii Nicole \& Manceaux 1909 em populações indígenas brasileiras com diferentes graus de aculturação". $01 / 03 / 2002$

1v. 98p. Mestrado. FUNDAÇÃO OSWALDO CRUZ - BIOLOGIA PARASITÁRIA

Orientador(es): Maria Regina Reis Amendoeira

Biblioteca Depositaria: Biblioteca de Manguinhos

Daniele Marcelle Grannier Rodrigues. ASPECTOS DA MORFOSSINTAXE DO GUARANI ANTIGO.. 01/05/2002

2v. 96p. Doutorado. UNIVERSIDADE FEDERAL DE ALAGOAS - LETRAS E LINGÜÍSTICA

Orientador(es): Adair Pimentel Palácio; Januacele Francisca da Costa

Biblioteca Depositaria: Biblioteca Setorial do PPGLL 
Deise Lucy Oliveira Montardo. Através do Mbaraka:Música e xamanismo guarani.. $01 / 08 / 2002$

1v. 276p. Doutorado. UNIVERSIDADE DE SÃO PAULO - CIÊNCIA SOCIAL (ANTROPOLOGIA SOCIAL)

Orientador(es): Lux Boelitz Vidal

Biblioteca Depositaria: Ciências Sociais

Elaine Aparecida Mye Takamatu Watanabe. Meio Ambiente e saúde indígena: o caso da reserva indígena de Dourados-MS. 01/06/2002

1v. 90p. Profissionalizante. UNIVERSIDADE DE BRASÍLIA DESENVOLVIMENTO SUSTENTÁVEL

Orientador(es): Umberto Euzebio

Biblioteca Depositaria: Biblioteca Central da Universidade de Brasília

Hilda Ribeiro Romero. Mapeamento dos Sítios Arqueológicos datados nas Sub-bacias dos Rios Iguatemi, Ivinhema, Pardo e Verde, na Bacia do Rio Paraná/MS. 01/09/2002

4v. 0p. Mestrado. FUNDAÇÃO UNIVERSIDADE FEDERAL DE MATO GROSSO DO SUL - GEOGRAFIA

Orientador(es): Gilson Rodolfo Martins

Biblioteca Depositaria: Campis de Aquidauana, Dourados e Biblioteca Nacional

José Manfroi. O Papel da Escola no Contexto Atual dos Kaiowá/Guarani da Aldeia TE’Y KUÊ de Caarapó. Um estudo a partir de lideranças e professores indígenas. 01/06/2002

1v. 220p. Doutorado. UNIVERSIDADE EST.PAULISTA JÚLIO DE MESQUITA FILHO/MARILIA - EDUCAÇÃO

Orientador(es): MAURO CHEROBIM

Biblioteca Depositaria: FFC-MARÍLIA

Júlio César de Moraes. Condições do solo em áreas de pousio dos cultivos praticados por índios Guarani, em Ubatuba (SP). 01/04/2002

1v. 174p. Doutorado. UNIVERSIDADE EST.PAULISTA JÚLIO DE MESQUITA FILHO/BOTUCATU - AGRONOMIA (ENERGIA NA AGRICULTURA)

Orientador(es): Ademercio Antonio Paccola

Biblioteca Depositaria: Prof. Paulo de Carvalho Mattos

Kátia Maria Bianchini Dallanhol. Jeroky e Jerojy: por uma antropologia da música entre os Mbyá-Guarani do Morro dos Cavalos. 01/02/2002

1v. 150p. Mestrado. UNIVERSIDADE FEDERAL DE SANTA CATARINA ANTROPOLOGIA SOCIAL

Orientador(es): Rafael José de Menezes Bastos

Biblioteca Depositaria: UFSC

MAURO SÉRGIO VIANELLO PINTO. Análise econômica e energética de sistema agroflorestal para implantação na terra indígena Araribá - município de Avaí/SP. 01/03/2002

1v. 136p. Mestrado. UNIVERSIDADE EST.PAULISTA JÚLIO DE MESQUITA FILHO/BOTUCATU - AGRONOMIA (ENERGIA NA AGRICULTURA) 
Orientador(es): Maristela Simões do Carmo

Biblioteca Depositaria: Prof. Paulo de Carvalho Mattos

Neimar Machado de Sousa. A redução de Nuestra Señora de la fe no Itatim: entre a cruz e a espada (1631-1659).. 01/09/2002

1v. 123p. Mestrado. FUNDAÇÃO UNIVERSIDADE FEDERAL DE MATO GROSSO

DO SUL - HISTÓRIA

Orientador(es): Eudes Fernando Leite

Biblioteca Depositaria: Biblioteca da UFMS - Campus de Dourados

PEDRO DE ABREU GASPAR. Polimorfismos dos genes do citocromo P450, da glutationa S-transferase e do supressor de tumor TP53 em populações sul-americanas e em pacientes com doença pulmonar obstrutiva e câncer de pulmão. 01/03/2002

1v. 120p. Doutorado. UNIVERSIDADE FEDERAL DO RIO GRANDE DO SUL GENÉTICA E BIOLOGIA MOLECULAR

Orientador(es): Tania de Azevedo Weimer

Biblioteca Depositaria: Biblioteca Setorial do Instituto de Biociências

ROSELENE MOREIRA GOMES MARTINS. Da construção à desconstrução do espaço reducional: o caso de San Nicolás.. 01/05/2002

1v. 233p. Mestrado. UNIVERSIDADE DO VALE DO RIO DOS SINOS - HISTÓRIA

Orientador(es): PAULA CALEFFI

Biblioteca Depositaria: Biblioteca Central da UNISINOS

SANDRA ESPÍNDOLA DA SILVA. Breve estudo do português oral dos índios da reserva Francisco Horta Barbosa - Dourados - MS. 01/10/2002

1v. 143p. Mestrado. UNIVERSIDADE EST.PAULISTA JÚLIO DE MESQUITA FILHO/ASSIS - LETRAS

Orientador(es): PEDRO CARUSO

Biblioteca Depositaria: FCL

Sarah Iurkiv Gomes Tibes Ribeiro. O Horizonte é a terra: manipulação da identidade e construção do 'ser' entre os guarani no oeste do Paraná (1977-1997). 01/10/2002

1v. 4301p. Doutorado. PONTIFÍCIA UNIVERSIDADE CATÓLICA DO RIO GRANDE DO SUL - HISTÓRIA

Orientador(es): Maria Cristina dos Santos

Biblioteca Depositaria: Biblioteca Irmão José Otão/PUCRS

Solange Nunes de Oliveira. A Arqueologia Guarani: construção e desconstrução da identidade indígena. 01/02/2002

1v. 135p. Mestrado. UNIVERSIDADE ESTADUAL DE CAMPINAS - HISTÓRIA

Orientador(es): Pedro Paulo Abreu Funari

Biblioteca Depositaria: Biblioteca do IFCH

Tatiana Azambuja Ujacow Martins. Diálogo Intertextual entre o Direito Kaiowá/Guarani e o Direito Positivo Brasileiro em uma Perspectiva da Dignidade da Pessoa Humana. 01/10/2002 
1v. 271p. Mestrado. UNIVERSIDADE DE BRASÍLIA - DIREITO

Orientador(es): Roberto Armando Ramos de Aguiar

Biblioteca Depositaria: Biblioteca Central da Universidade de Brasília

Vânia Maria Oliveira de Freitas. Religião e Guerra nas Missões Jesuíticas Platinas. 01/09/2002

1v. 100p. Mestrado. PONTIFÍCIA UNIVERSIDADE CATÓLICA DO RIO GRANDE DO SUL - HISTÓRIA

Orientador(es): Maria Cristina dos Santos

Biblioteca Depositaria: Biblioteca Irmão José Otão/PUCRS

Vera Lúcia de Oliveira. Mba'evyky: o que a gente faz. Cotidiano e Cosmologia Guarani Mbyä.. 01/12/2002

1v. 187p. Mestrado. UNIVERSIDADE FEDERAL DO RIO DE JANEIRO SOCIOLOGIA E ANTROPOLOGIA

Orientador(es): MARCO ANTONIO TEIXEIRA GONCALVES

Biblioteca Depositaria: IFCS

VERONICE LOVATO ROSSATO. OS RESULTADOS DA ESCOLARIZAÇÃO ENTRE OS KAIOWÁ E GUARANI EM MATO GROSSO DO SUL - "SERÁ O LETRAO AINDA UM DOS NOSSOS"?. 01/12/2002

2v. 164p. Mestrado. UNIVERSIDADE CATÓLICA DOM BOSCO - EDUCAÇÃO

Orientador(es): ANTONIO JACO BRAND

Biblioteca Depositaria: FÉLIX ZAVATTARO - UCDB

2003

Adilson Manfrin. Loreto (1610-1631): Guyraypoty do Pirapó.. 01/12/2003

1v. 143p. Mestrado. FUNDAÇÃO UNIVERSIDADE FEDERAL DE MATO GROSSO

DO SUL - HISTÓRIA

Orientador(es): Marina Evaristo Wenceslau

Biblioteca Depositaria: Biblioteca da UFMS - Campus de Dourados

Adriana Cristina Albernaz. Tradição, mudança e o sentido da história entre os Kaiowá Guarani. 01/08/2003

1v. 165p. Mestrado. UNIVERSIDADE FEDERAL DO PARANÁ - ANTROPOLOGIA SOCIAL

Orientador(es): Marnio Teixeira Pinto

Biblioteca Depositaria: Biblioteca Central da UFPR

Adriana Schmidt Dias. Sistemas de assentamento e Estilo Tecnologico: uma proposta interpretativa para a ocupacao pre-colonial do Alto Vale do Rio dos Sinos, Rio Grande do Sul.. 01/09/2003

11v. 402p. Doutorado. UNIVERSIDADE DE SÃO PAULO - ARQUEOLOGIA

Orientador(es): Paulo Antonio Dantas De Blasis 
Biblioteca Depositaria: FFLCH

ANA CLAUDIA GALVÃO NOGUEIRA DE CASTRO. Estudo audiométrico em aldeias indígenas do estado de São Paulo.. 01/03/2003

1v. 107p. Mestrado. UNIVERSIDADE DE SÃO PAULO - CIÊNCIAS (FISIOPATOLOGIA EXPERIMENTAL)

Orientador(es): RENATA MOTA MAMEDE CARVALLO

Biblioteca Depositaria: FACULDADE DE MEDICINA DA UNIVERSIDADE DE SÃO PAULO

ANDREA RITA MARRERO. Os gaúchos: sua história evolutivaa revelada a partir de marcadores genéticos. 01/07/2003

1v. 132p. Mestrado. UNIVERSIDADE FEDERAL DO RIO GRANDE DO SUL GENÉTICA E BIOLOGIA MOLECULAR

Orientador(es): Maria Catira Bortolini

Biblioteca Depositaria: Biblioteca Setorial do Instituto de Biociências

Consuelo de Paiva Godinho Costa. Nhandewa Aywu. 01/02/2003

1v. 168p. Mestrado. UNIVERSIDADE ESTADUAL DE CAMPINAS - LINGÜÍSTICA

Orientador(es): WILMAR DA ROCHA D'ANGELIS

Biblioteca Depositaria: Biblioteca Central

Eunice AT Cunha. Avaliação epidemiológica e operacionalização para diagnóstico da tuberculose na população indígena Guarani-Kaiuwá do estado de Mato Grosso do Sul. $01 / 07 / 2003$

1v. 50p. Mestrado. FUNDAÇÃO UNIVERSIDADE FEDERAL DE MATO GROSSO DO SUL - SAÚDE COLETIVA

Orientador(es): Michael Robin Honer

Biblioteca Depositaria: UFMS

FABIANA BARZOTI KOHLRAUSCH. Estudo da variabilidade de 15 microssatélites em quatro populações indígenas sul-americanas. 01/02/2003

1v. 88p. Mestrado. UNIVERSIDADE FEDERAL DO RIO GRANDE DO SUL GENÉTICA E BIOLOGIA MOLECULAR

Orientador(es): Mara Helena Hutz; SIDIA MARIA CALLEGARI JACQUES

Biblioteca Depositaria: Biblioteca Setorial do Instituto de Biociências

Giane Saraiva Sampaio Vargas. Sistema de Informações como Ferramentas de Apoio do Desenvolvimento Local no Âmbito do Programa Kaiowá/Guarani. 01/04/2003

1v. 113p. Mestrado. UNIVERSIDADE CATÓLICA DOM BOSCO DESENVOLVIMENTO LOCAL

Orientador(es): Antonio Jacó Brand

Biblioteca Depositaria: Biblioteca Pe. Félix Zavattaro

José Exequiel Basini Rodriguez. "Índios num País sem Índios: a estética do desaparecimento. Um estudo sobre imagens índias e versões étnicas no Uruguai.. 01/02/2003 
1v. 505p. Doutorado. UNIVERSIDADE FEDERAL DO RIO GRANDE DO SUL ANTROPOLOGIA SOCIAL

Orientador(es): Ari Pedro Oro

Biblioteca Depositaria: Biblioteca Setorial de Ciências Sociais e Humanidades

Luiza Tamie Tsuneto. "Polimorfismo HLA em cinco populações ameríndias".. 01/02/2003

2v. 117p. Doutorado. UNIVERSIDADE FEDERAL DO PARANÁ - GENÉTICA

Orientador(es): Maria Luiza Petzl-Erler

Biblioteca Depositaria: Biblioteca Central da Universidade Federal do Paraná

Marci Fileti Martins. Descrição e Análise de Aspectos da Gramática do Guarani Mbyá. $01 / 02 / 2003$

1v. 157p. Doutorado. UNIVERSIDADE ESTADUAL DE CAMPINAS LINGÜÍSTICA

Orientador(es): LUCY SEKI

Biblioteca Depositaria: Biblioteca Central

Márcia Gomes de Oliveira. Terra, Fome, e Cidadania Indígena. 01/03/2003

1v. 154p. Mestrado. UNIVERSIDADE FEDERAL FLUMINENSE - SOCIOLOGIA E DIREITO

Orientador(es): André Laino

Biblioteca Depositaria: Biblioteca Central do Gragoatá

Maria das Graças Ferreira. Contrapontos da literatra Indígena Contemporânea no Brasil.. $01 / 03 / 2003$

1v. 100p. Doutorado. UNIVERSIDADE FEDERAL DE PERNAMBUCO - LETRAS

Orientador(es): ROLAND GERHARD MIKE WALTER

Biblioteca Depositaria: BC, PG

Maria Denise Bortolini. ENTRE O TEMPORAL E O ETERNO: Corpo e sentidos nas missões jesuíticas do Paraguai nos séculos XVII e XVIII. 01/02/2003

1v. 153p. Mestrado. UNIVERSIDADE FEDERAL DE SANTA CATARINA HISTÓRIA

Orientador(es): Valmir Francisco Muraro

Biblioteca Depositaria: Biblioteca Central

Mirian Baptista Carle. Investigação arqueológica em Rio Grande: uma proposta da ocupação guarani pré-histórica no Rio Grande do Sul. 01/01/2003

1v. 173p. Mestrado. PONTIFÍCIA UNIVERSIDADE CATÓLICA DO RIO GRANDE

DO SUL - HISTÓRIA

Orientador(es): Klaus Peter Kristian Hilbert

Biblioteca Depositaria: Biblioteca Irmão José Otão - PUCRS

OSÉIAS DE OLIVEIRA. INDÍOS E JESUÍTAS NO GUAIRÁ: A REDUÇÃO COMO ESPAÇO DE REINTERPRETAÇÃO CULTURAL.. 01/04/2003

1v. 224p. Doutorado. UNIVERSIDADE EST.PAULISTA JÚLIO DE MESQUITA 
FILHO/ASSIS - HISTÓRIA

Orientador(es): BENEDITO MIGUEL ANGELO PERRINI GIL

Biblioteca Depositaria: UNESP-ASSIS

Paulo Henrique Bataglin Machado. Qualidade de Vida em Paranaguá, uma Perspectiva Local. $01 / 12 / 2003$

1v. 230p. Doutorado. UNIVERSIDADE FEDERAL DO PARANÁ - MEIO AMBIENTE E DESENVOLVIMENTO

Orientador(es): Carolyn Stephens; FRANCISCO DE ASSIS MENDONÇA

Biblioteca Depositaria: Biblioteca da UFPR

Rita de Cássia Aparecida Pacheco Limberti. A imagem do índio:discursos e representações. $01 / 10 / 2003$

1v. 278p. Doutorado. UNIVERSIDADE DE SÃO PAULO - LINGÜÍSTICA

Orientador(es): Diana Luz Pessoa de Barros

Biblioteca Depositaria: Biblioteca de Letras/FFLCH/USP

RUTH HENRIQUE DA SILVA. CARTOGRAFIA NATIVA: A REPRESENTAÇÃO DO TERRITÓRIO, PELOS GUARANI KAIOWÁ, PARA O PROCEDIMENTO ADMINISTRATIVO DE VERIFICAÇÃO DA FUNAI. 01/06/2003

2v. 105p. Mestrado. UNIVERSIDADE FEDERAL FLUMINENSE ANTROPOLOGIA

Orientador(es): ELIANE CANTARINO O'DWYER

Biblioteca Depositaria: BIBLIOTECA CENTRAL DO GRAGOATÁ

Sônia da Silva Rodrigues. KAINGANG, OTI-XAVANTE E GUARANI NO POVOAMENTO DO VALE DO PARANAPANEMA.. 01/10/2003

1v. 166p. Mestrado. PONTIFÍCIA UNIVERSIDADE CATÓLICA DE SÃO PAULO HISTÓRIA

Orientador(es): Maria Angélica V.M.C. Soler

Biblioteca Depositaria: Biblioteca Nadir Gouvea Kfouri

Valdirene Ganz. "Os Mbyá e a Natureza: um ensaio bibliográfico". 01/09/2003

1v. 153p. Mestrado. UNIVERSIDADE FEDERAL DO PARANÁ - ANTROPOLOGIA SOCIAL

Orientador(es): Edilene Coffaci de Lima

Biblioteca Depositaria: BIBLIOTECA UFPR

Valéria Esteves Nascimento Barros. Da casa de rezas à Congregação Cristã no Brasil:o pentecostalismo Guarani na terra indígena Laranjinha/PR. 01/02/2003

1v. 119p. Mestrado. UNIVERSIDADE FEDERAL DE SANTA CATARINA ANTROPOLOGIA SOCIAL

Orientador(es): Antonella Maria Imperatriz Tassinari

Biblioteca Depositaria: Biblioteca Central UFSC 
Angela Ariadne Hofmann. Karaí Nhe?e Katu: discussões em torno da escola em um comunidade Guarani|. 01/03/2004

1v. 211p. Mestrado. UNIVERSIDADE DO VALE DO RIO DOS SINOS EDUCAÇÃO

Orientador(es): Beatriz Terezinha Daudt Fischer

Biblioteca Depositaria: Universidade do Vale do Rio dos Sinos - UNISINOS

Dione da Rocha Bandeira. Ceramistas Pré-Coloniais da Baía da Babitonga - SC: Arqueologia e Etnicidade.. 01/02/2004

1v. 273p. Doutorado. UNIVERSIDADE ESTADUAL DE CAMPINAS - HISTÓRIA

Orientador(es): Pedro Paulo Abreu Funari

Biblioteca Depositaria: Biblioteca do IFCH e Biblioteca Central da Unicamp

Djanires Lageano de Jesus. A TRANSFORMAÇÃO DA RESERVA INDÍGENA DE DOURADOS-MS EM TERRITÓRIO TURÍSTICO: VALORIZAÇÃO SÓCIOECONÔMICA E CULTURAL. 01/12/2004

1v. 172p. Mestrado. FUNDAÇÃO UNIVERSIDADE FEDERAL DE MATO GROSSO

DO SUL - GEOGRAFIA

Orientador(es): Edvaldo Cesar Moretti

Biblioteca Depositaria: Biblioteca do Campus de Aquidauana - UFMS

Elbrio Martins Rodrigues. A CULTURA MATERIAL MISSIONEIRA NO RIO GRANDE DO SUL COMO BASE PARA O ESTUDO DE BRINQUEDOS CONTEMPORÂNEOS. $01 / 03 / 2004$

3v. 259p. Mestrado. UNIVERSIDADE FEDERAL DE SANTA MARIA ENGENHARIA DE PRODUÇÃO

Orientador(es): Ligia Maria Sampaio de Medeiros

Biblioteca Depositaria: Biblioteca Central e Biblioteca Setorial do CT

Everaldo Rocha Ramos de Oliveira. Do território a aldeia ao terreno da imagem. Uma reflexão sobre imagem, discurso e identidades. 01/09/2004

1v. 90p. Mestrado. UNIVERSIDADE FEDERAL FLUMINENSE - COMUNICAÇÃO

Orientador(es): Tania Conceição Clemente de Souza

Biblioteca Depositaria: Biblioteca do Gragoatá

Gustavo Peretti Wagner. Ceramistas Pré-Coloniais do Litoral Norte.. 01/07/2004

1v. 321p. Mestrado. PONTIFÍCIA UNIVERSIDADE CATÓLICA DO RIO GRANDE DO SUL - HISTÓRIA

Orientador(es): Klaus Peter Kristian Hilbert

Biblioteca Depositaria: Biblioteca Central da PUCRS - Irmão José Otão

Jean Tiago Baptista. Jesuítas e Guarani na Pastoral do Medo: As Variáveis do Discurso Missionário Sobre a Natureza (1610-1650). 01/05/2004

1v. 149p. Mestrado. PONTIFÍCIA UNIVERSIDADE CATÓLICA DO RIO GRANDE 


\section{DO SUL - HISTÓRIA}

Orientador(es): Maria Cristina dos Santos

Biblioteca Depositaria: Biblioteca Central da PUCRS - Irmão José Otão

João Lopes de Oliveira Filho. Planejamento do uso da terra índigena Arariba no município de Avaí/SP, através de um sistema de informações geográficas. 01/09/2004

1v. 72p. Mestrado. UNIVERSIDADE EST.PAULISTA JÚLIO DE MESQUITA FILHO/BOTUCATU - AGRONOMIA (ENERGIA NA AGRICULTURA)

Orientador(es): Célia Regina Lopes Zimback

Biblioteca Depositaria: Biblioteca "Prof. Paulo de Carvalho Mattos" - FCA/UNESP

Luis Augusto Cândido Benatti. O conhecimento tradicional dos Kaiowá-Guarani e o processo de etnodesenvolivmento na reserva indígena de Caarapó-MS. 01/09/2004

1v. 85p. Mestrado. UNIVERSIDADE CATÓLICA DOM BOSCO DESENVOLVIMENTO LOCAL

Orientador(es): Reginaldo Brito da Costa

Biblioteca Depositaria: Pe. Félix Zavattaro

Maria de Fatima Mommensohn. Ayvu Rapyta - O Fundamento da palavra.. 01/02/2004

1v. 115p. Mestrado. UNIVERSIDADE ESTADUAL DE CAMPINAS - ARTES

Orientador(es): REGINA APARECIDA POLO MULLER

Biblioteca Depositaria: Biblioteca Central

MARIA DOROTHEA POST DARELLA. Ore Roipota Yvy Porã ? ?Nós Queremos Terra Boa? - Territorialização Guarani No Litoral De Santa Catarina ? Brasil. 01/11/2004

1v. 414p. Doutorado. PONTIFÍCIA UNIVERSIDADE CATÓLICA DE SÃO PAULO CIÊNCIAS SOCIAIS - ANTROPOLOGIA

Orientador(es): Rinaldo Sérgio Vieira Arruda

Biblioteca Depositaria: PUC/SP

Melissa Santana de Oliveira. "kÿringué i kuery Guarani: infância, educação e religião entre os Guarani de M'Biguaçu. 01/03/2004

1v. 112p. Mestrado. UNIVERSIDADE FEDERAL DE SANTA CATARINA ANTROPOLOGIA SOCIAL

Orientador(es): Antonella Maria Imperatriz Tassinari

Biblioteca Depositaria: Biblioteca Universitária

NADIR LURDES DAMIANI. Cultura material, patrimônio e educação: as reduções Jesuítico-Guarani e o ensino de história.. 01/04/2004

1v. 139p. Mestrado. UNIVERSIDADE DO VALE DO RIO DOS SINOS - HISTÓRIA

Orientador(es): MARIA CRISTINA BOHN MARTINS

Biblioteca Depositaria: Biblioteca Central da UNISINOS

Rosely Aparecida Stefanes Pacheco. Mobilizações Guarani Kaiowá e Nãndeva e a (Re)Contrução de Territórios (1978-2003). 01/10/2004

4v. 187p. Mestrado. FUNDAÇÃO UNIVERSIDADE FEDERAL DE MATO GROSSO 
DO SUL - HISTÓRIA

Orientador(es): Osvaldo Zorzato

Biblioteca Depositaria: Biblioteca Nacional, da UFMS, Centro de Documentação/UFMS

Symonne Pimentel Castro de Oliveira Lima Parizotto. Prevalência de cárie dentária na dentição decídua de crianças da comunidade indígena Kaiowá-Guarani de Mato Grosso do Sul e associação com fatores de risco. 01/12/2004

1v. 111p. Doutorado. UNIVERSIDADE DE SÃO PAULO - CIÊNCIAS ODONTOLÓGICAS

Orientador(es): Célia Regina Martins Delgado Rodrigues

Biblioteca Depositaria: SDO-FOUSP

Yolanda Lopes da Silveira. Estudo etnobotânico das plantas medicinais utilizadas pelos índios Mbyá-Guarani da Terra Indígena de Cantagalo, Viamão, RS, para a saúde bucal. ESTA DISSERTAÇÃO ESTÁ VINCULADA À ANTIGA ÁREA DE CONCENTRAÇÃO DE "ATENÇÃO À SAÚDE".. 01/01/2004

1v. 152p. Mestrado. UNIVERSIDADE LUTERANA DO BRASIL - SAÚDE COLETIVA

Orientador(es): Elaine da Silveira

Biblioteca Depositaria: Universidade Luterana do Brasil

\section{7}

Diane Maria Scherer Khun Lago . O índio idoso Kaiowá : memórias e histórias de vida. 12/04/2007.

1v. 273p. Mestrado. Universidade Católica de Brasilia - GERONTOLOGIA

Orientador(es): Vicente de Paula Faleiros 
Anexo B:

Diagramas de parentesco 

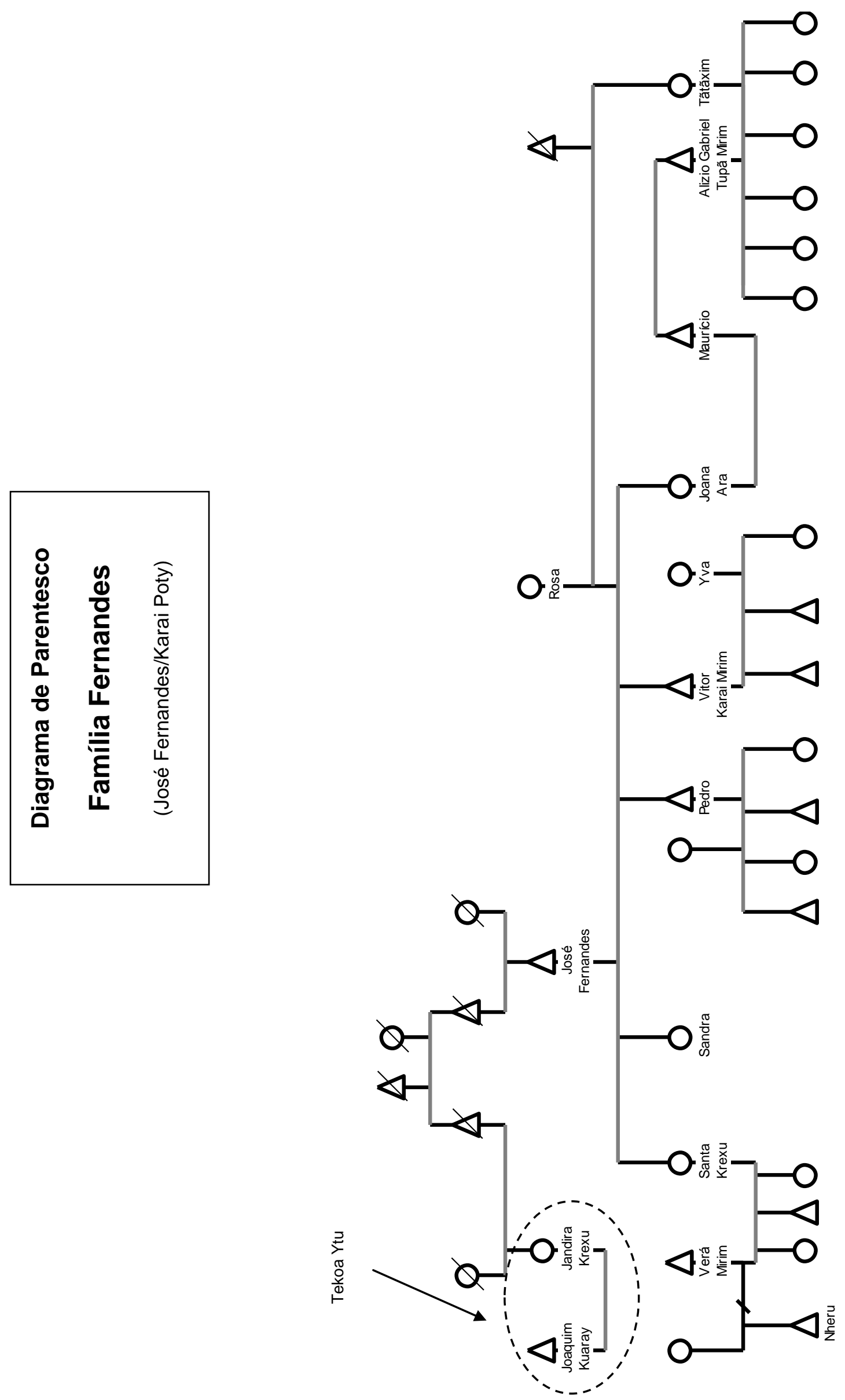

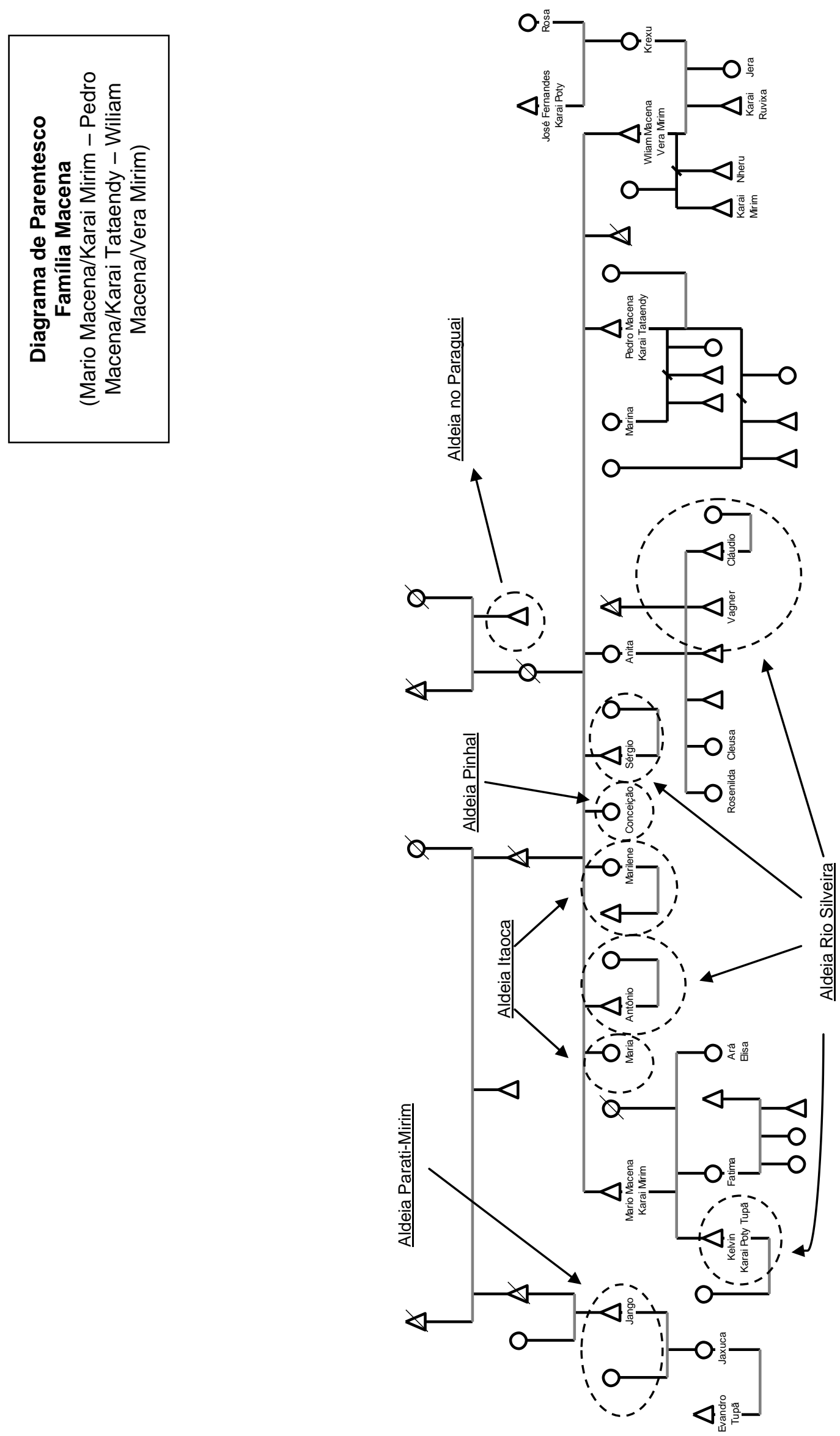

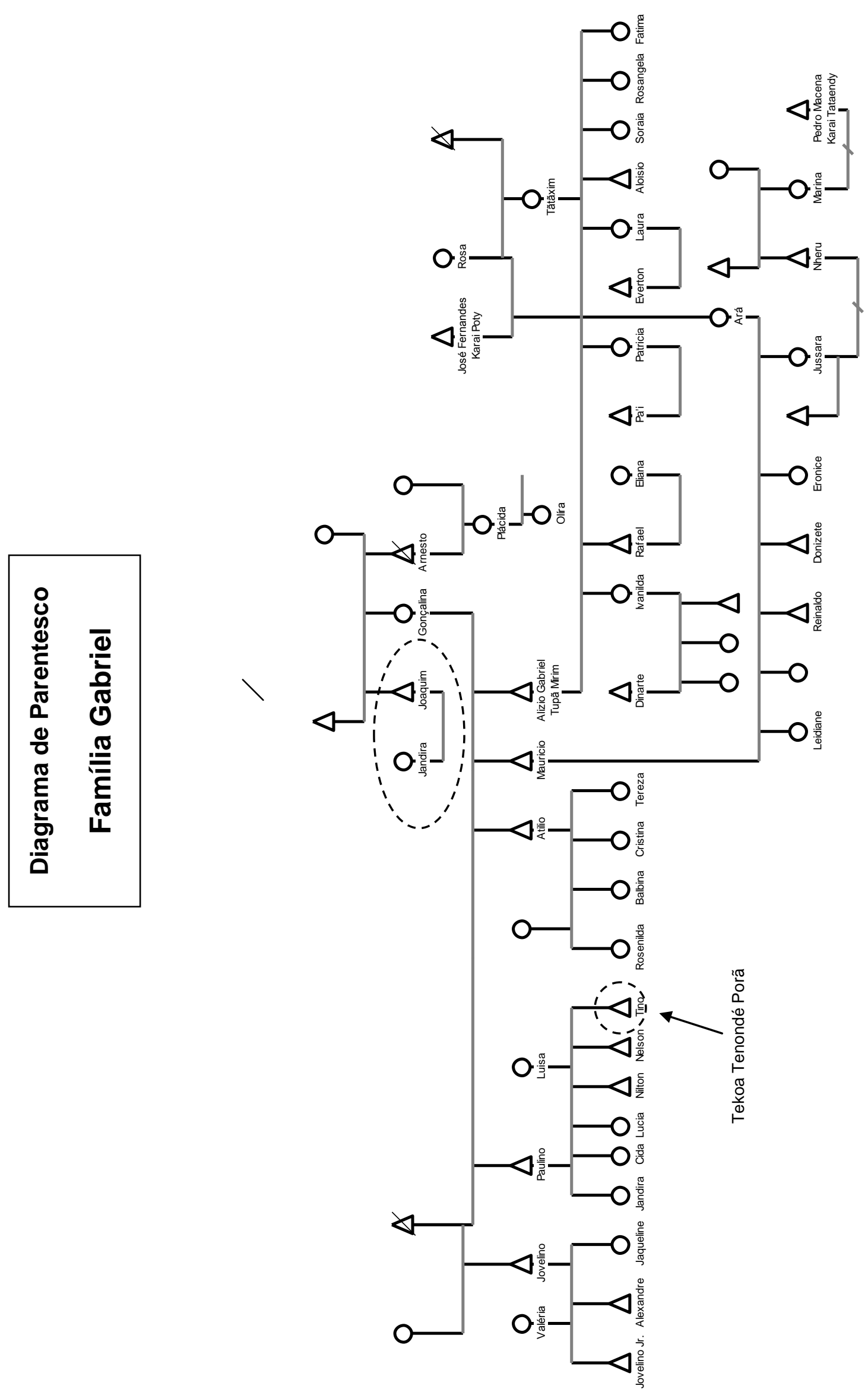

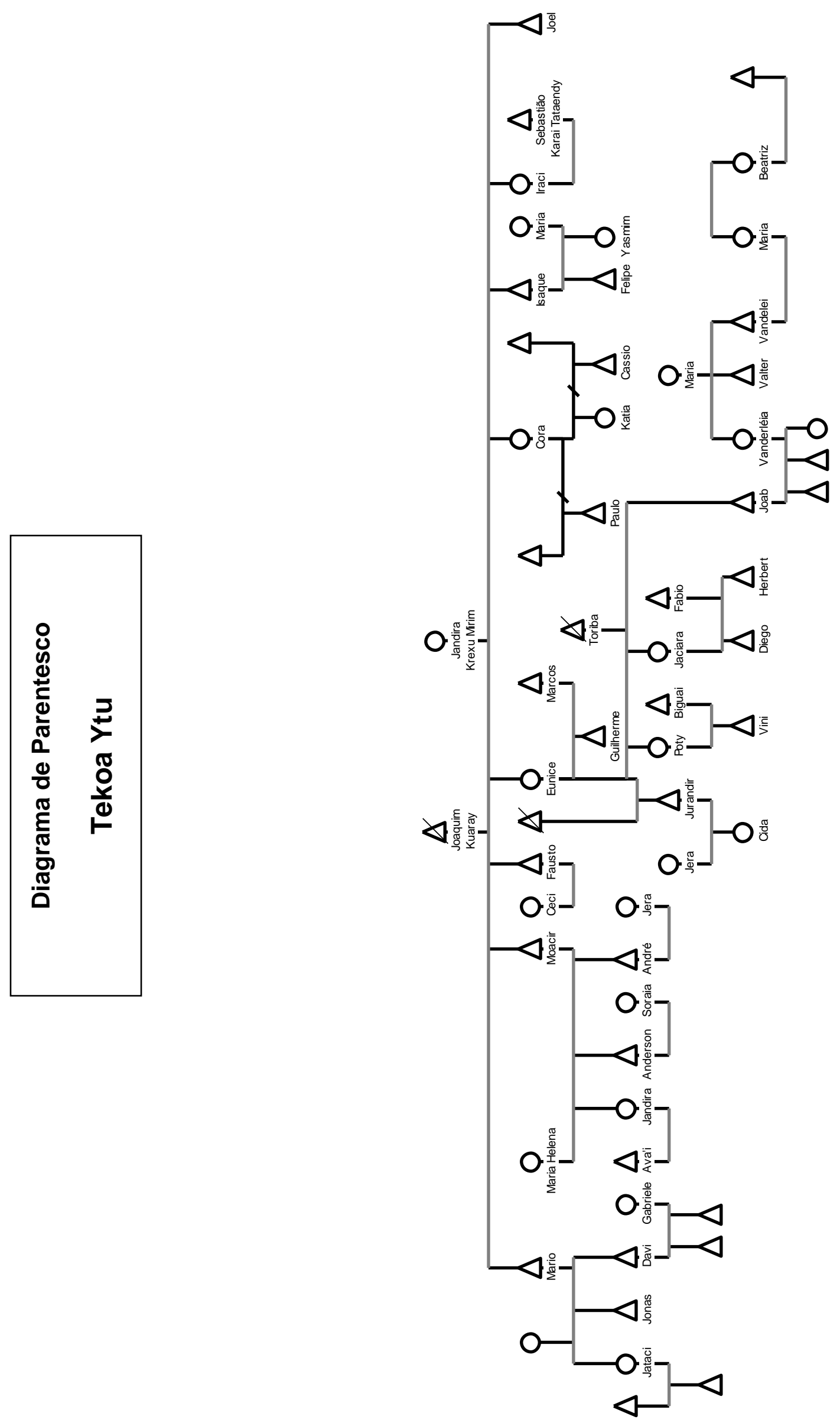
Anexo C:

Croqui da aldeia Tekoá Pyaú 
Localização das Famílias no croqui:

\begin{tabular}{|c|c|c|c|}
\hline №noCroqui & Família/Núcleo & № de famílias & Representantes das Residências \\
\hline 1 & Núcleo Tupã Mirim & 6 & Tupã Mirim, Rafael, Gonçalina, Cristina, Ivanilda, \\
\hline 2 & Núcleo Karaí Poty & 8 & Karaí Poty, Ronaldo, Patrícia, Elcio, Wiliam, \\
\hline 3 & Pedro Macena & 1 & Pedro \\
\hline 4 & Rosenilda Souza & 1 & Rosenilda \\
\hline 5 & Romildo & 1 & Romildo \\
\hline 6 & Núcleo Vítor & 2 & Vitor, Jandira \\
\hline 7 & Núcleo Fabio & 3 & Fabio, Marcos, Jonatan \\
\hline 8 & Mateus & 1 & Mateus \\
\hline 9 & Mário & 1 & Mário \\
\hline 10 & Ana & 1 & Ana \\
\hline 11 & Tiago & 1 & Tiago \\
\hline 12 & Núcelo Rosenilda & 2 & Rosenilda, Cleuza \\
\hline 13 & Núcleo Neide & 2 & Adilson, Neide \\
\hline 14 & Miguel & 1 & Miguel \\
\hline 15 & Ronaldo & 1 & Ronaldo \\
\hline 16 & Evandro & 1 & Evandro \\
\hline 17 & Lúcia & 1 & Lúcia \\
\hline 18 & Maurício & 1 & Maurício \\
\hline 19 & Silvia & 1 & Silvia \\
\hline 20 & Núcleo Ari & 2 & Ari, Lúcio \\
\hline 21 & Núcleo Paulinho & 5 & Paulinho, Márcia, Nilton, Alcino, Olimpio \\
\hline 22 & Alcides & 1 & Alcides \\
\hline 23 & Marina & 4 & Jorge, Marina, Fabio, Valquiria \\
\hline 24 & Núcleo Jovino & 2 & Jovino, Carlito \\
\hline 25 & Núclo Natalício & 2 & Natalício, Nelson \\
\hline 26 & Roberto & 1 & Roberto \\
\hline 27 & Tonico & 1 & Tonico \\
\hline 28 & Nelson & 1 & Nelson \\
\hline \multirow[t]{2}{*}{29} & Antônio & 1 & Antônio \\
\hline & TOTAL & 56 & \\
\hline
\end{tabular}




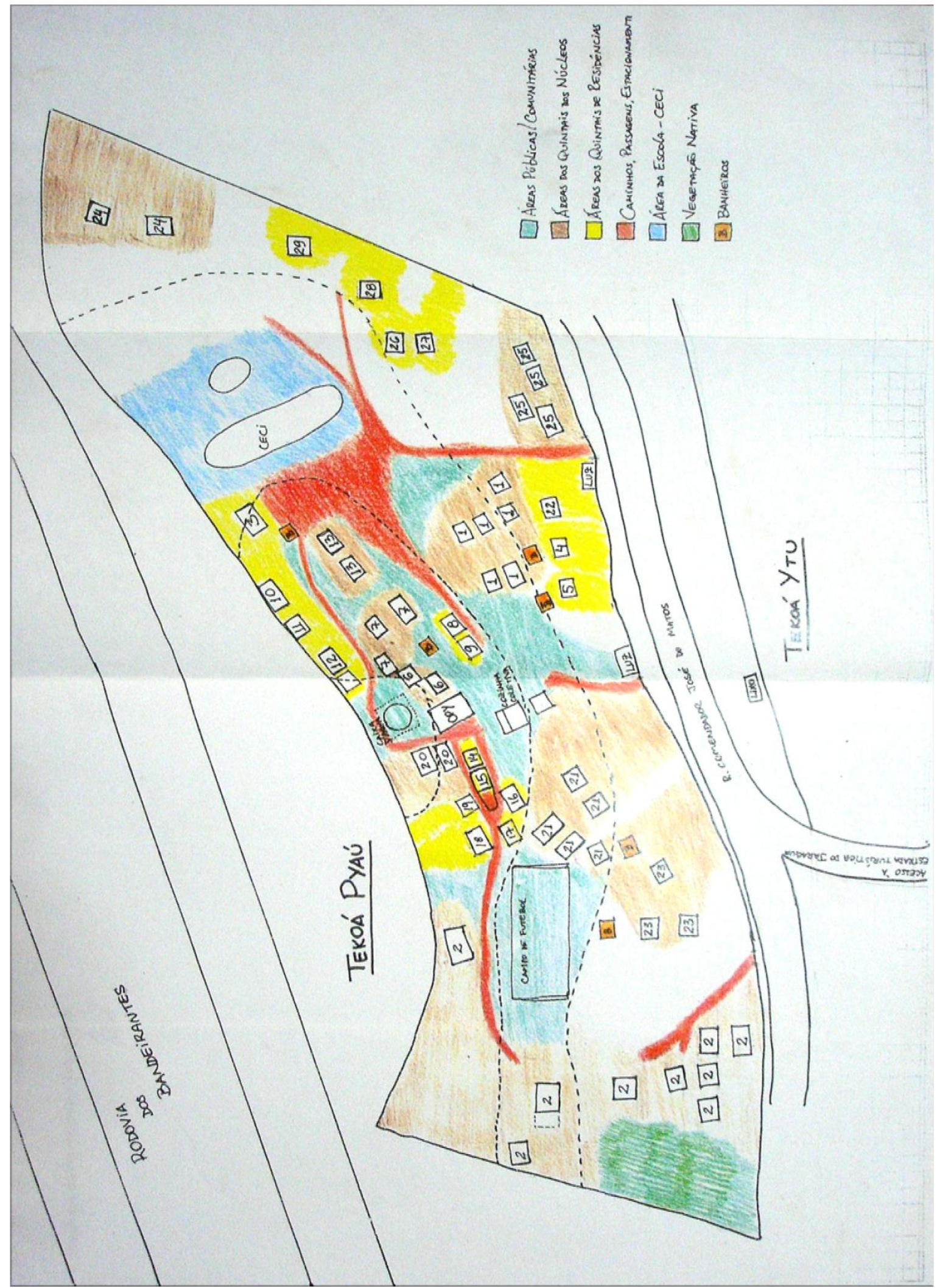




\section{Anexo D:}

\section{As aldeias Guarani Mbya e a região do Jaraguá}

Notas:

1 - A delimitação da aldeia Tekoa Ytu já está definida por meio de procedimento administrativo da Funai. A representação do local da aldeia sobre a foto tem apenas o objetivo de localizar a aldeia no mapa, e não traduz sua delimitação real.

2 - A área onde se encontra a aldeia Tekoa Pyau está em processo de demarcação. A representação do local da aldeia Tekoa Pyau sobre a foto tem apenas o objetivo de localizar as moradias da referida aldeia na região, e não traduz sua delimitação real, nem a totalidade dos espaços utilizados efetivamente pelos Mbya do Jaraguá, que inclui locais como os de coleta de remédios e de material para a produção de artesanato. 


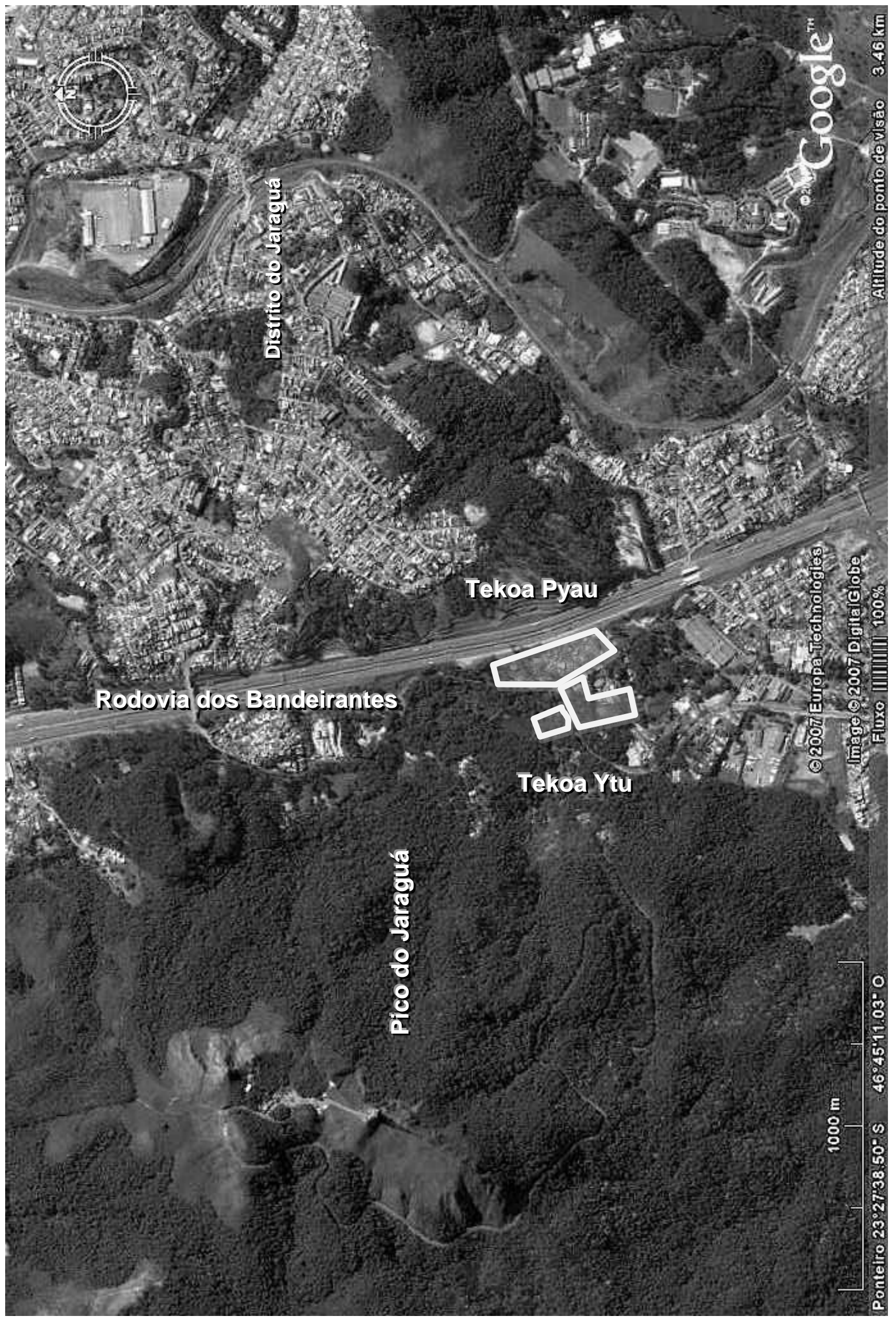




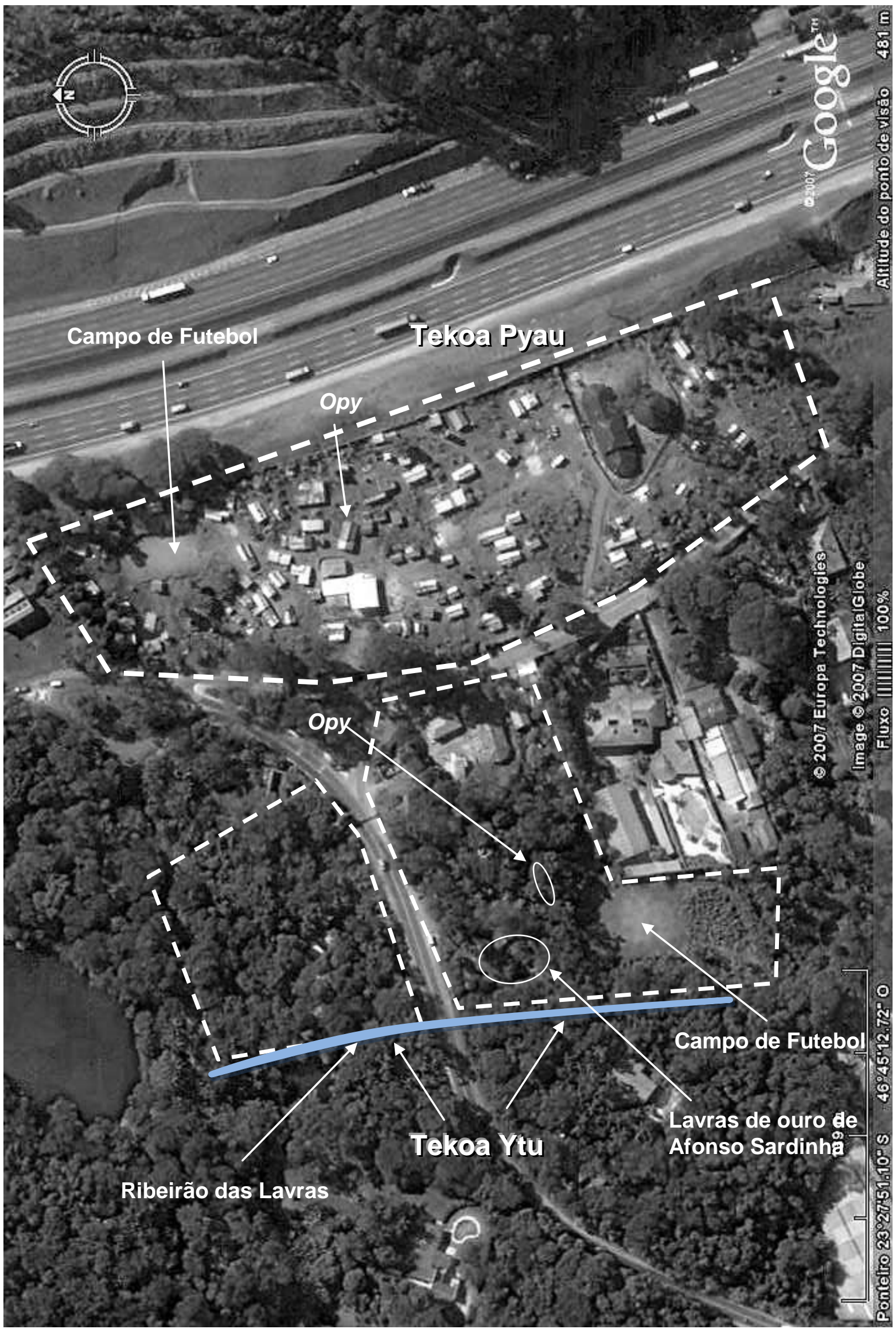




\section{Anexo E:}

Diagramas de organização sócio-espacial:

Kaiowá e Mbya 


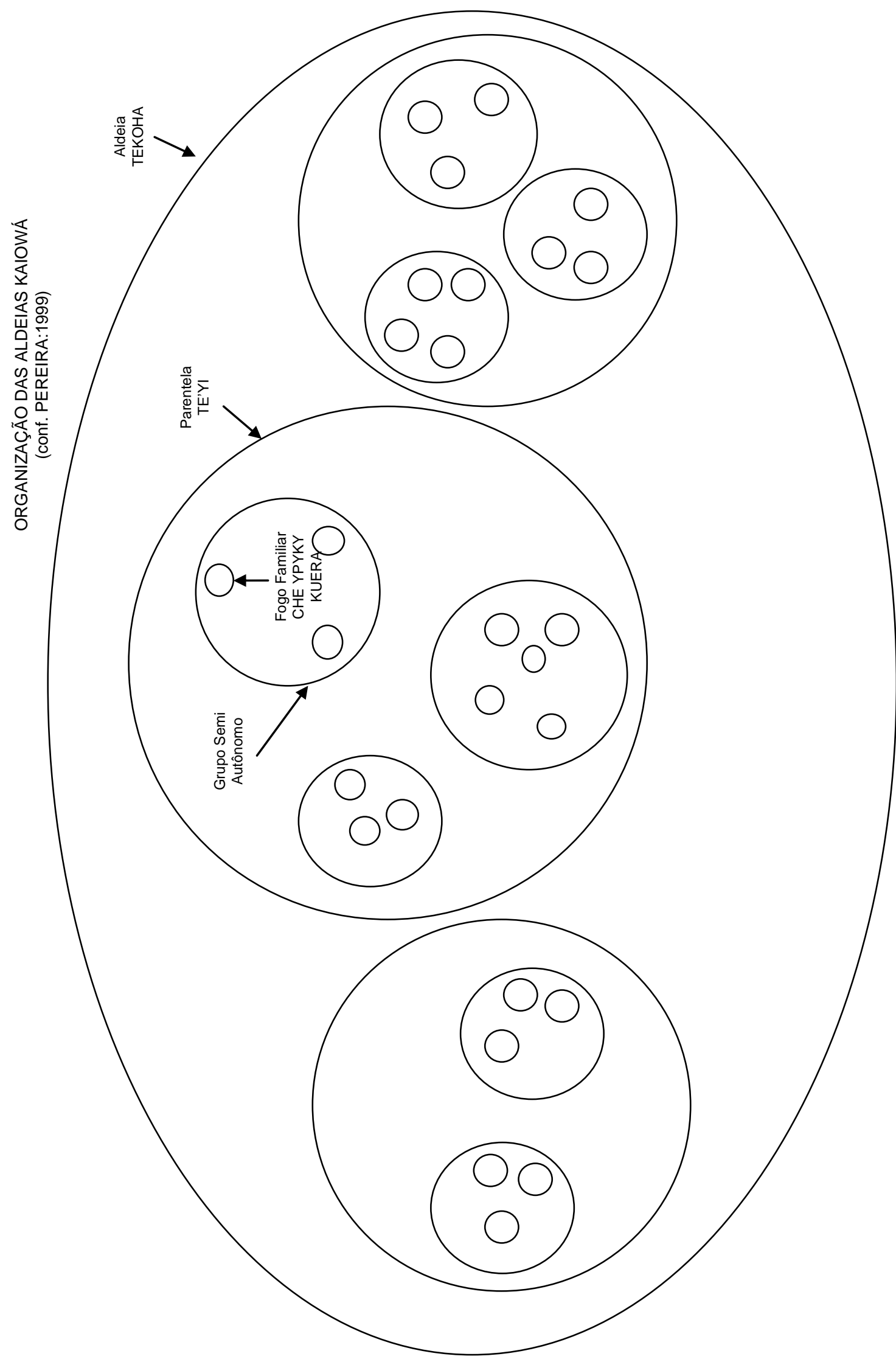




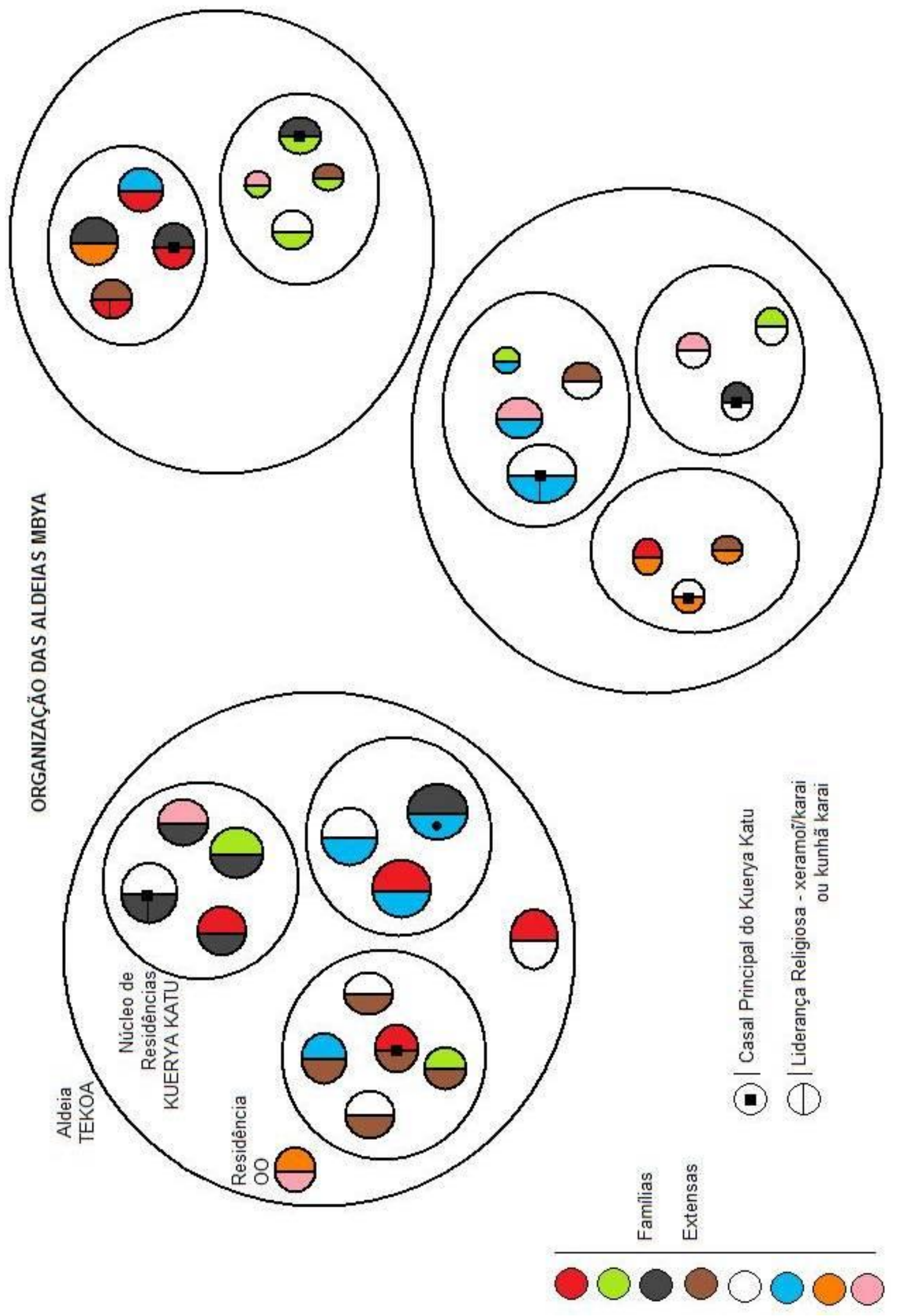

